\title{
Geographical Distribution of Biomass Carbon in Tropical Southeast Asian Forests: A Database
}

Sandra Brown

Louis R. Iverson
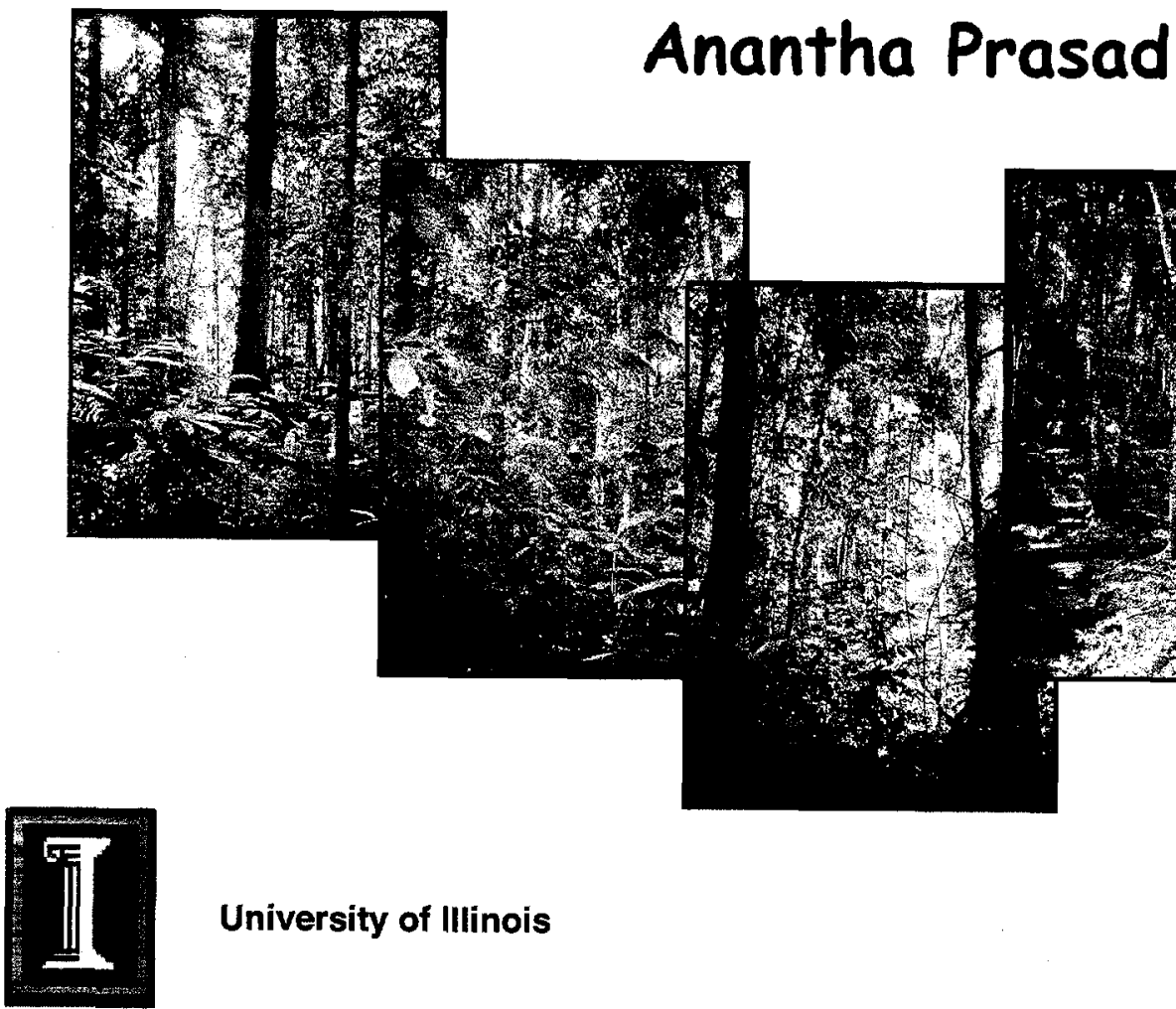

University of Illinois

Carbon Dioxide Information Analysis Center Oak Ridge National Laboratory

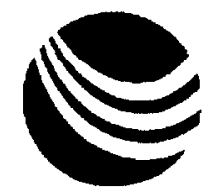

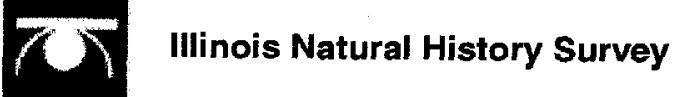




\title{
DOCUMENT AVAILABILITY
}

Reports produced after January 1, 1996, are generally available free via the U.S. Department of Energy (DOE) Information Bridge.

\section{Web site http://www.osti.gov/bridge}

Reports produced before January 1,1996 , may be purchased by members of the public from the following source.

\author{
National Technical Information Service \\ 5285 Port Royal Road \\ Springfield, VA 22161 \\ Telephone 703-605-6000 (1-800-553-6847) \\ TDD 703-487-4639 \\ Fax 703-605-6900 \\ E-mail info@ntis.fedworld.gov \\ Web site http://www.ntis.gov/support/ordernowabout.htm
}

Reports are available to DOE employees, DOE contractors, Energy Technology Data Exchange (ETDE) representatives, and International Nuclear Information System (INIS) representatives from the following source.

Office of Scientific and Technical Information

P.O. Box 62

Oak Ridge, TN 37831

Telephone 865-576-8401

Fax 865-576-5728

E-mail reports@adonis.osti.gov

Web site http://www.osti.gov/contact.html

\footnotetext{
This report was prepared as an account of work sponsored by an agency of the United States Government. Neither the United States Government nor any agency thereof, nor any of their employees, makes any warranty, express or implied, or assumes any legal liability or responsibility for the accuracy, completeness, or usefulness of any information, apparatus, product, or process disclosed, or represents that its use would not infringe privately owned rights. Reference herein to any specific commercial product, process, or service by trade name, trademark, manufacturer, or otherwise, does not necessarily constitute or imply its endorsement, recommendation, or favoring by the United States Government or any agency thereof. The views and opinions of authors expressed herein do not necessarily state or reflect those of the United States Government or any agency thereof.
} 


\title{
Geographical Distribution of Biomass Carbon in Tropical Southeast Asian Forests: A Database
}

\author{
Contributed by \\ Sandra Brown, ${ }^{1}$ Louis R. Iverson, ${ }^{2}$ and Anantha Prasad $^{2}$ \\ Department of Natural Resources and Environmental Sciences \\ University of Illinois \\ Urbana, Tllinois \\ and \\ Illinois Natural History Survey \\ Champaign, Illinois \\ ${ }^{1}$ Present address: Winrock International \\ Corvallis, Oregon \\ ${ }^{2}$ Present address: United States Forest Service \\ Northeast Research Station \\ Delaware, Ohio \\ Prepared by
}

Tammy W. Beaty, Lisa M. Olsen, Robert M. Cushman, and Antoinette L. Brenkert

Environmental Sciences Division

Environmental Sciences Division

Publication No. 4879

Date Published: March 2001

Prepared for the

Environmental Sciences Division

Office of Biological and Environmental Research

Budget Activity Number KP 1204010

Prepared by the

Carbon Dioxide Information Analysis Center

Environmental Sciences Division

OAK RIDGE NATIONAL LABORATORY

Oak Ridge, Tennessee 37831-6335

managed by

UT-BATTELLE, LLC

for the

U.S. DEPARTMENT OF ENERGY

under contract DE-AC05-00OR22725 


\section{CONTENTS}

LIST OF FIGURES $\ldots \ldots \ldots \ldots \ldots \ldots \ldots \ldots \ldots \ldots \ldots \ldots \ldots \ldots \ldots \ldots$

LIST OF TABLES $\ldots \ldots \ldots \ldots \ldots \ldots \ldots \ldots \ldots \ldots \ldots \ldots \ldots \ldots$ vii

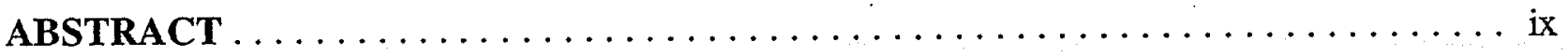

1. BACKGROUND INFORMATION $\ldots \ldots \ldots \ldots \ldots \ldots \ldots \ldots \ldots \ldots \ldots \ldots$

2. APPLICATIONS OF THE DATA $\ldots \ldots \ldots \ldots \ldots \ldots \ldots \ldots \ldots \ldots \ldots \ldots$

3. DATA LIMITATIONS AND RESTRICTIONS $\ldots \ldots \ldots \ldots \ldots \ldots \ldots \ldots$

4. QUALITY-ASSURANCE CHECKS AND DATA-PROCESSING ACTIVITIES

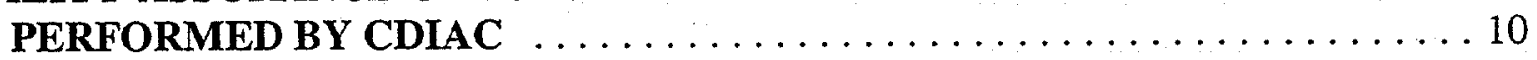

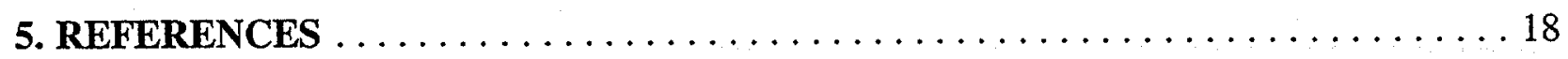

6. HOW TO OBTAIN THE DATA AND DOCUMENTATION . . . . . . . . . . 19

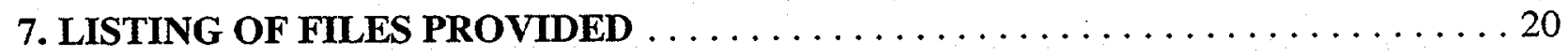

8. DESCRIPTION OF THE DOCUMENTATION FILE $\ldots \ldots \ldots \ldots \ldots \ldots$

9. DESCRIPTION, FORMAT, AND PARTIAL LISTINGS

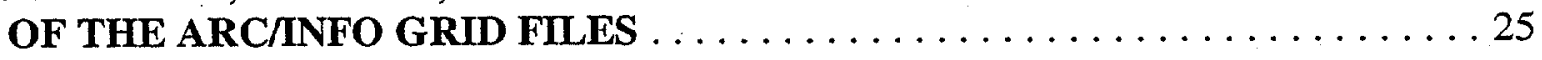

10. DESCRIPTION, FORMAT, AND PARTIAL LISTINGS OF THE 24 ASCII

DATA FILES PRODUCED BY THE ARCINFO GRIDASCII COMMAND . . . . 37

11. DESCRIPTION, FORMAT, AND PARTIAL LISTING OF THE

COMPOSITE 3.75-KM AND 0.25-DEGREE ASCII DATA FILES . . . . . . . . 44

12. STATISTICS OF THE FILES PROVIDED IN THIS NUMERIC

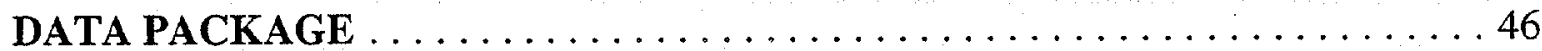

APPENDIX A: REPRINT OF PERTINENT LITERATURE $\ldots \ldots \ldots \ldots \ldots \ldots$

Geographical Distributions of Carbon in Biomass and Soils of Tropical Asian

Forests, by S. Brown, L. R. Iverson, A. Prasad, and D. Liu. 1993 . . . . . . . . A-3 


\section{LIST OF FIGURES}

$\begin{array}{lll}\text { Figure } & \text { Page }\end{array}$

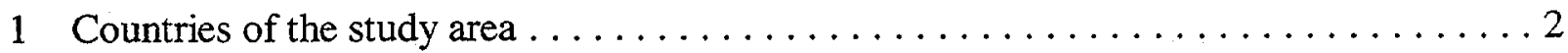

2 Mean elevation for the study area, displayed with 0.25 -degree resolution . . . . . . . 3

3 Soil texture class for the study area, displayed with 0.25 -degree resolution . . . . . . . 3

4 Mean slope class for the study area, displayed with 0.25 -degree resolution ......... 4

5 Mean annual precipitation for the study area, displayed with 0.25 -degree resolution . . . . 4

6 Weck's Climatic Index for the study area, displayed with 0.25 -degree resolution $\ldots . \ldots 5$.

7 Forest/non-forest classification of the study area,

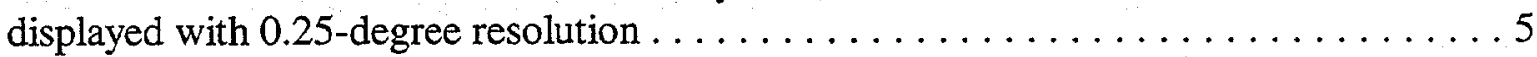

8 Potential carbon densities in forests of the study area, displayed with 0.25 -degree resolution $\ldots \ldots \ldots \ldots \ldots \ldots \ldots \ldots \ldots \ldots$

9 Vegetation type in the study area, displayed with 0.25 -degree resolution $\ldots \ldots \ldots \ldots 6$

10 Ecofloristic zone classification for the study area,

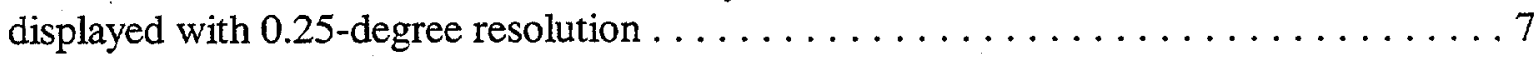

11 Population density in the study area, displayed with 0.25 -degree resolution $\ldots \ldots \ldots 8$

12 Actual carbon densities in forests of the study area, displayed with 0.25 -degree resolution $\ldots \ldots \ldots \ldots \ldots \ldots \ldots \ldots \ldots \ldots$ 


\section{LIST OF TABLES}

Table

Page

1 Redistribution of the data as a result of the resampling process $\ldots \ldots \ldots \ldots \ldots$

2 GRIDASCII syntax used to produce the ASCII data files . . . . . . . . . . . 16

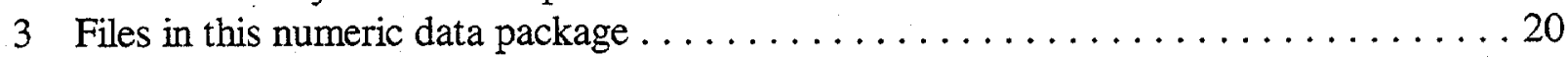

4 Item descriptions for the ten ARC/NNFO export grids . . . . . . . . . . . . 26

5 Format and description of variables for the composite ASCII data files in this numeric data package (se_asia.dat and se_asiax.dat) $\ldots \ldots \ldots \ldots \ldots \ldots \ldots$

6 Item statistics for the data files in this numeric data package $\ldots \ldots \ldots \ldots \ldots \ldots$ 


\begin{abstract}
BROWN, S., L. R. IVERSON, AND A. PRASAD. 2001. Geographical Distribution of Biomass Carbon in Tropical Southeast Asian Forests: A Database. ORNL/CDIAC-119, NDP-068. Carbon Dioxide Information Analysis Center, U.S. Department of Energy, Oak Ridge National Laboratory, Oak Ridge, Tennessee, U.S.A. 75 pp.

A database was generated of estimates of geographically referenced carbon densities of forest vegetation in tropical Southeast Asia for 1980. A geographic information system (GIS) was used to incorporate spatial databases of climatic, edaphic, and geomorphological indices and vegetation to estimate potential (i.e., in the absence of human intervention and natural disturbance) carbon densities of forests. The resulting map was then modified to estimate actual 1980 carbon density as a function of population density and climatic zone. The database covers the following 13 countries: Bangladesh, Brunei, Cambodia (Campuchea), India, Indonesia, Laos, Malaysia, Myanmar (Burma), Nepal, the Philippines, Sri Lanka, Thailand, and Vietnam.
\end{abstract}

The data sets within this database are provided in three file formats: ARC/INFO ${ }^{\mathrm{TM}}$ exported integer grids, ASCII (American Standard Code for Information Interchange) files formatted for raster-based GIS software packages, and generic ASCII files with $x, y$ coordinates for use with non-GIS software packages.

This database includes ten ARC/NFO exported integer grid files (five with the pixel size $3.75 \mathrm{~km} \times 3.75 \mathrm{~km}$ and five with the pixel size 0.25 degree longitude $\times 0.25$ degree latitude) and 27 ASCII files. The first ASCII file contains the documentation associated with this database. Twenty-four of the ASCII files were generated by means of the ARC/INFO GRIDASCII command and can be used by most raster-based GIS software packages. The 24 files can be subdivided into two groups of 12 files each. These files contain real data values representing actual carbon and potential carbon density in $\mathrm{Mg} \mathrm{C} / \mathrm{ha}\left(1\right.$ megagram $=10^{6}$ grams $)$ and integercoded values for country name, Weck's Climatic Index, ecofloristic zone, elevation, forest or non-forest designation, population density, mean annual precipitation, slope, soil texture, and vegetation classification. One set of 12 files contains these data at a spatial resolution of 3.75 $\mathrm{km}$, whereas the other set of 12 files has a spatial resolution of 0.25 degree. The remaining two ASCII data files combine all of the data from the 24 ASCII data files into 2 single generic data files. The first file has a spatial resolution of $3.75 \mathrm{~km}$, and the second has a resolution of 0.25 degree. Both files also provide a grid-cell identification number and the longitude and latitude of the centerpoint of each grid cell.

The $3.75-\mathrm{km}$ data in this numeric data package yield an actual total carbon estimate of $42.1 \mathrm{Pg}$ ( 1 petagram $=10^{15}$ grams) and a potential carbon estimate of $73.6 \mathrm{Pg}$; whereas the 0.25 -degree data produced an actual total carbon estimate of $41.8 \mathrm{Pg}$ and a total potential carbon estimate of $73.9 \mathrm{Pg}$.

Fortran and SAS ${ }^{\mathrm{TM}}$ access codes are provided to read the ASCII data files, and ARC/INFO and ARCVIEW command syntax are provided to import the ARC/INFO exported integer grid files. 
The data files and this documentation are available without charge on a variety of media and via the Internet from the Carbon Dioxide Information Analysis Center (CDIAC).

Keywords: biomass, carbon, carbon cycle, climate, elevation, forest, land use, organic matter, population, slope, soil, Southeast Asia, tropics, vegetation 


\section{BACKGROUND INFORMATION}

Quantification of the role of changing land use in the global cycling of carbon (and, consequently, in controlling atmospheric concentrations of carbon dioxide, the single most important anthropogenic greenhouse gas) requires complete, consistent, and accurate databases of vegetation, land use, and biospheric carbon content. The Carbon Dioxide Information Analysis Center (CDIAC) has previously made available several important quality-assured and documented databases on this topic (Olson et al. 1985, Richards and Flint 1994, Houghton and Hackler 1995, and Brown et al. 1996).

This database (NDP-068) expands the series by providing detailed geographically referenced information on actual and potential biomass carbon $(1 \mathrm{~g}$ biomass $=0.5 \mathrm{~g} \mathrm{C})$ in tropical Southeast Asia and all the background information used to generate those files. A geographic information system (GIS) was used to incorporate spatial databases of climatic, edaphic, and geomorphological indices and vegetation to estimate potential (without human influence) carbon densities of forests in 1980. The resulting estimates were then modified to produce estimates of actual carbon density as a function of population density and climatic zone.

Estimates of carbon in the biomass (aboveground and belowground) of tropical Southeast Asian forests for the year 1980 were generated by means of a GIS modeling approach, on the basis of the assumption that "the present distribution of forest biomass density is a function of the potential biomass the landscape can support under the prevailing climatic, edaphic and geomorphological conditions and the cumulative impact of human activities such as logging, fuelwood collection, shifting cultivation, and other activities that reduce the biomass" (Brown et al. 1993). The database covers the following 13 countries: Bangladesh, Brunei, Cambodia (Campuchea), India, Indonesia, Laos, Malaysia [Peninsular (Malaya) and Insular (Sabah, also known as North Borneo, and Sarawak)], Myanmar (Burma), Nepal, the Philippines, Sri Lanka, Thailand, and Vietnam (Fig. 1).

A thorough description of the methods and data sources can be found in Brown et al. (1993). To calculate potential and actual aboveground biomass carbon densities, the general methodology of Risser and Iverson (1988) and Iverson et al. (1994) was followed. This consisted of a simple weighted additive model of data layers of elevation and slope, precipitation, Weck's Climatic Index, and soil texture to arrive at a score for potential biomass density for each pixel. Elevation data (Fig. 2) were derived from a U.S. National Geophysical Data Center elevation map; soil texture data (Fig. 3) and slope data (Fig. 4) were derived from the Soil Map of the World produced by the Food and Agriculture Organization (FAO) - United Nations Educational, Scientific, and Cultural Organization; and annual precipitation (Fig. 5) and a modified Weck's Climatic Index (Weck 1970) (Fig. 6) were interpolated from about 600 stations in the FAO agrometeorological database. Results were compared with independent ground-truth information and iteratively reprocessed to within certain bounds to obtain a satisfactory result. The map results were overlaid with forest/non-forest data (Fig. 7) from circa 1980, resulting in a map of potential carbon densities (Fig. 8). The forest/non-forest data were derived from a FAO vegetation map 
(Fig. 9) of continental tropical Southeast Asia and a World Conservation Monitoring Center map of forested areas of insular Asia. The resulting potential biomass was compared with ecofloristic zones (Fig. 10) derived from an FAO map, confirming the reasonableness of the model-derived estimates.

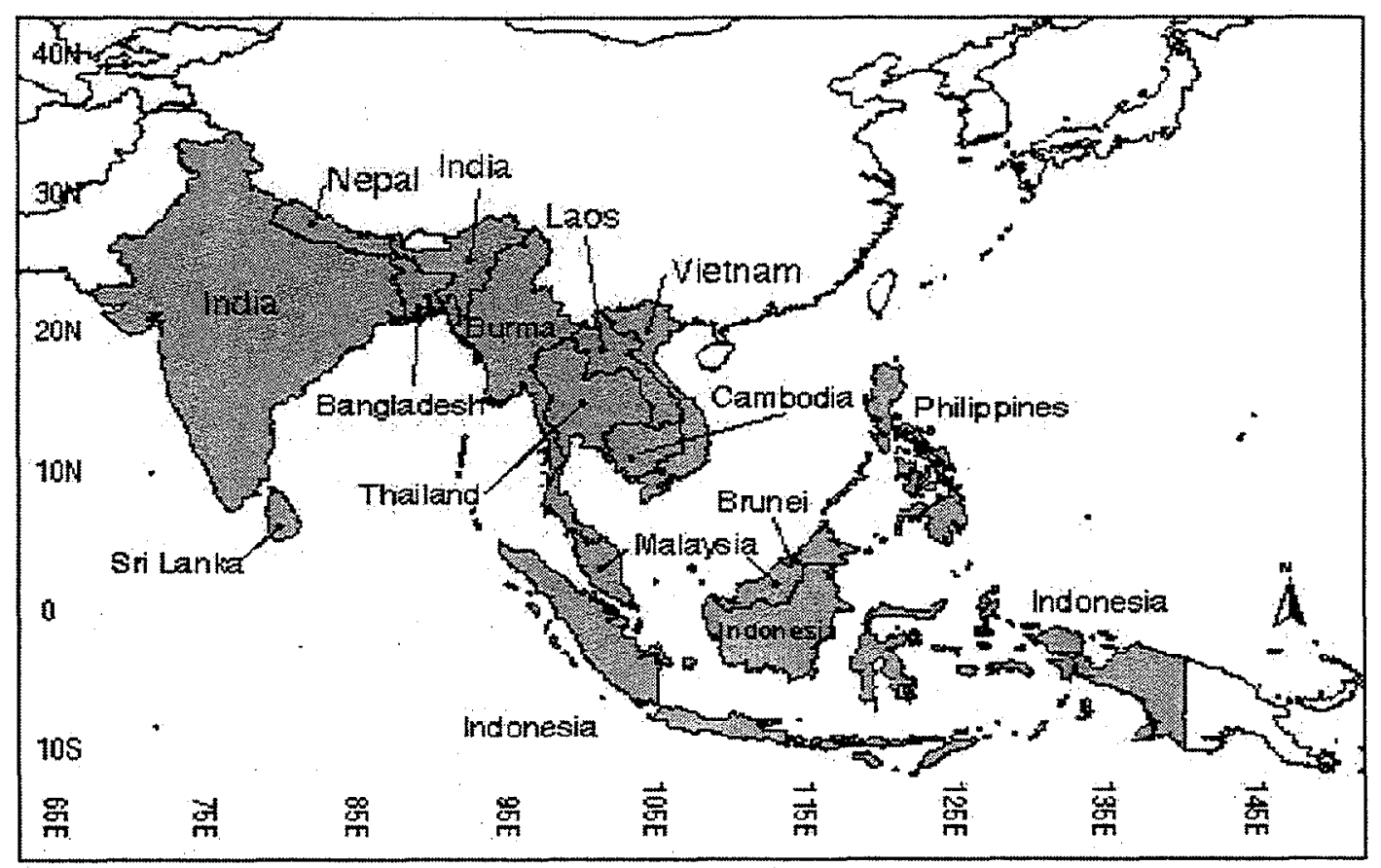

Fig. 1. Countries of the study area. 


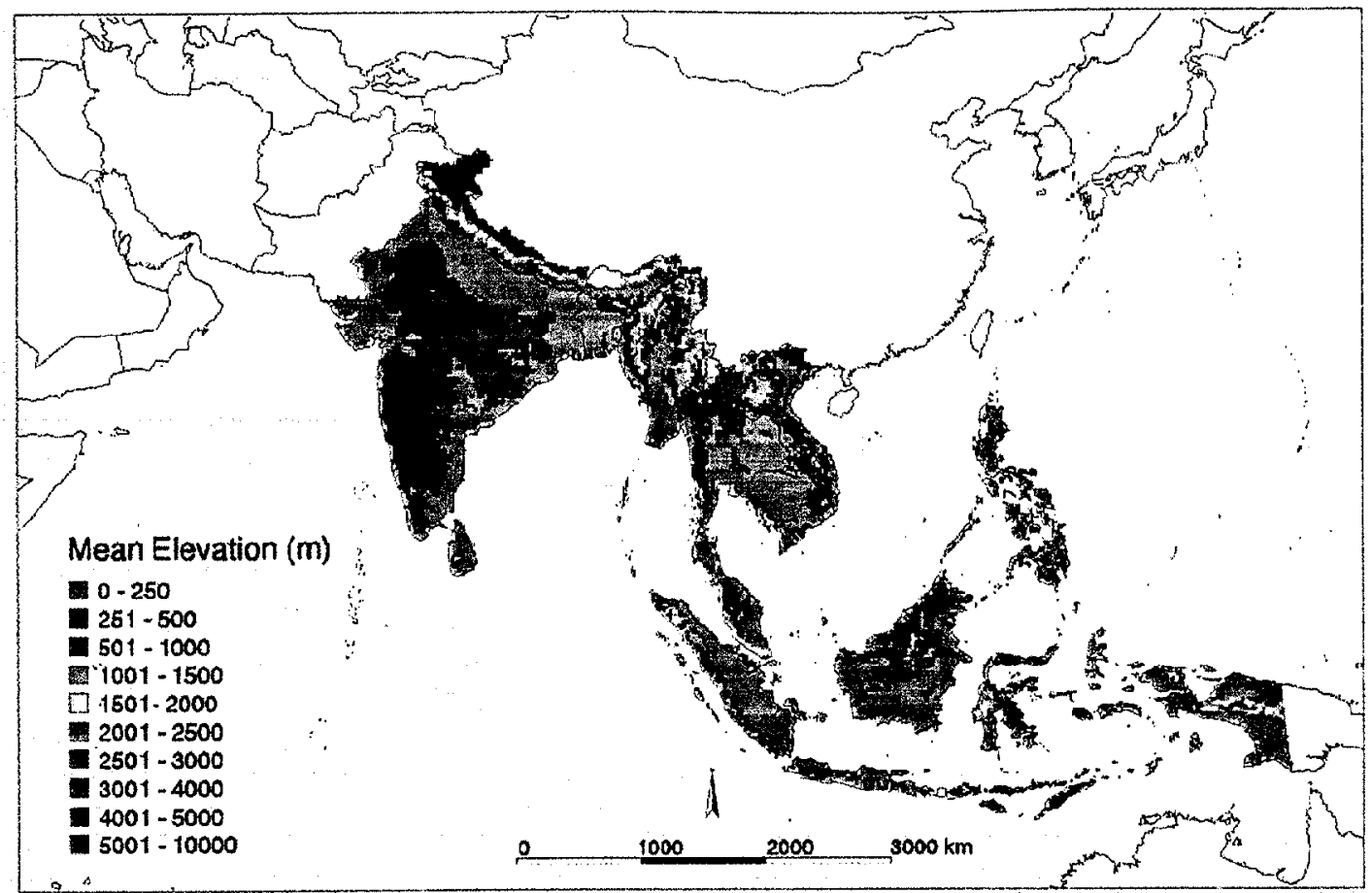

Fig. 2. Mean elevation for the study area, displayed with 0.25 -degree resolution.

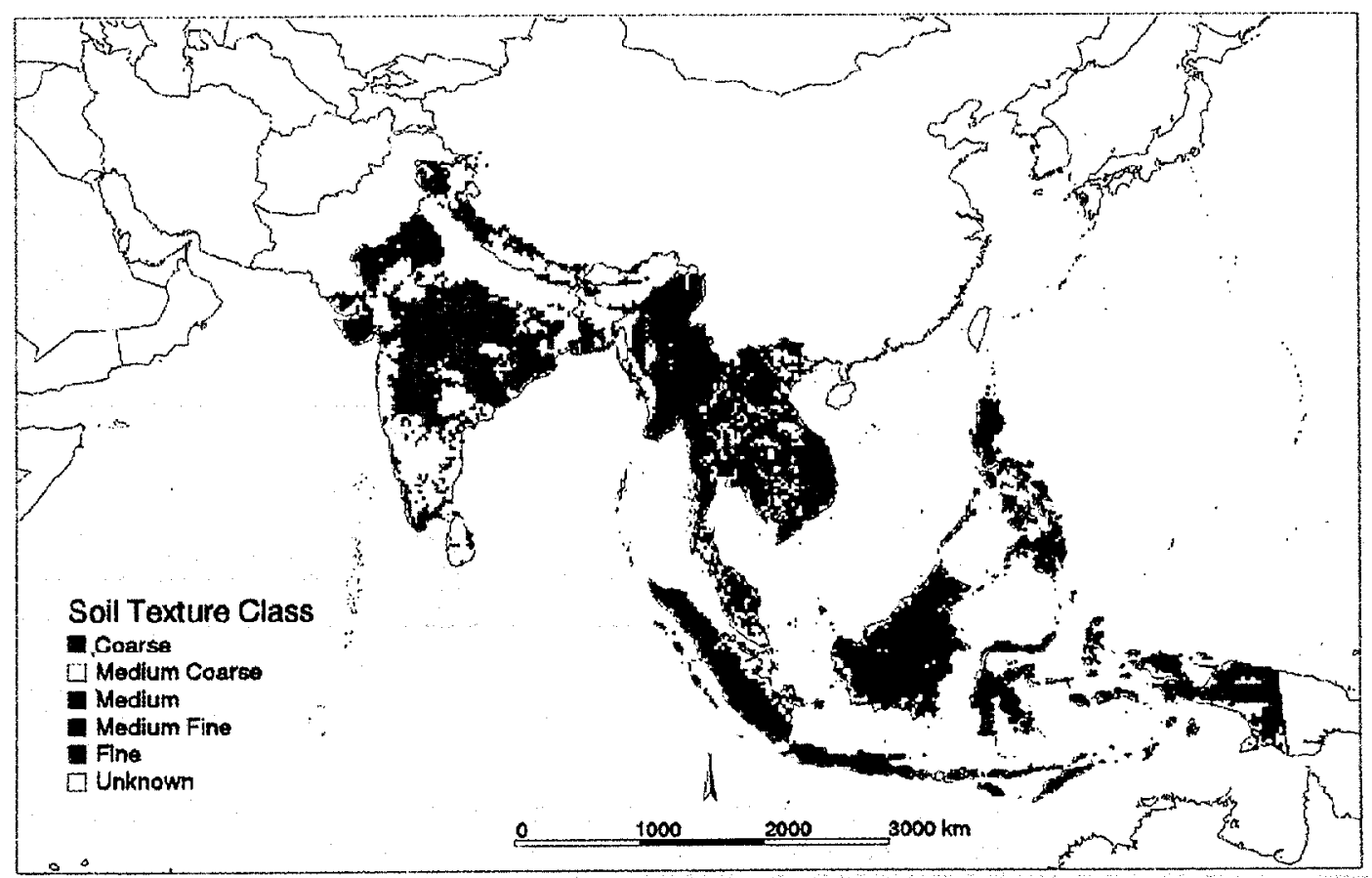

Fig. 3. Soil texture class for the study area, displayed with 0.25 -degree resolution. 


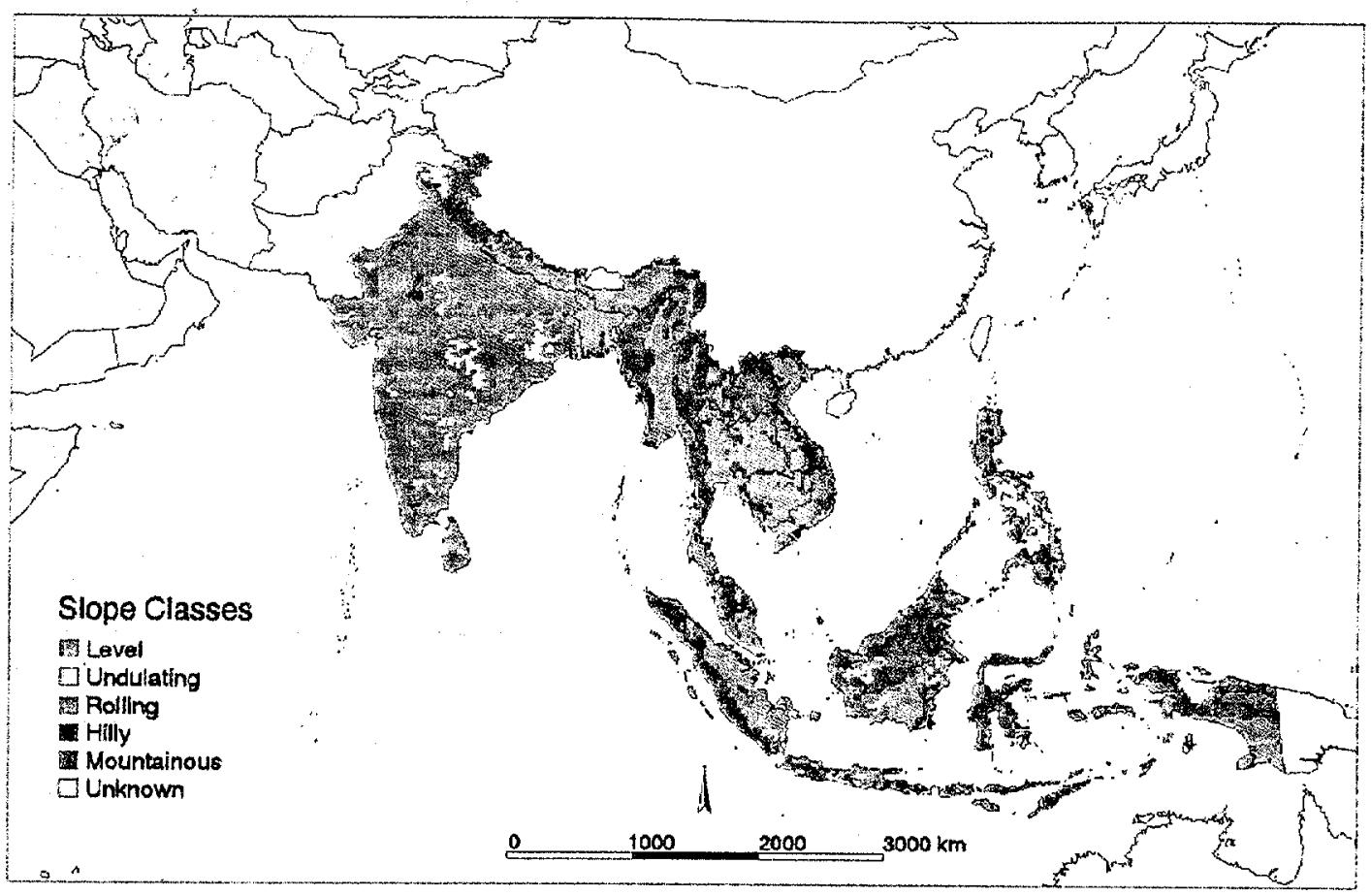

Fig. 4. Mean slope class for the study area, displayed with 0.25 -degree resolution.

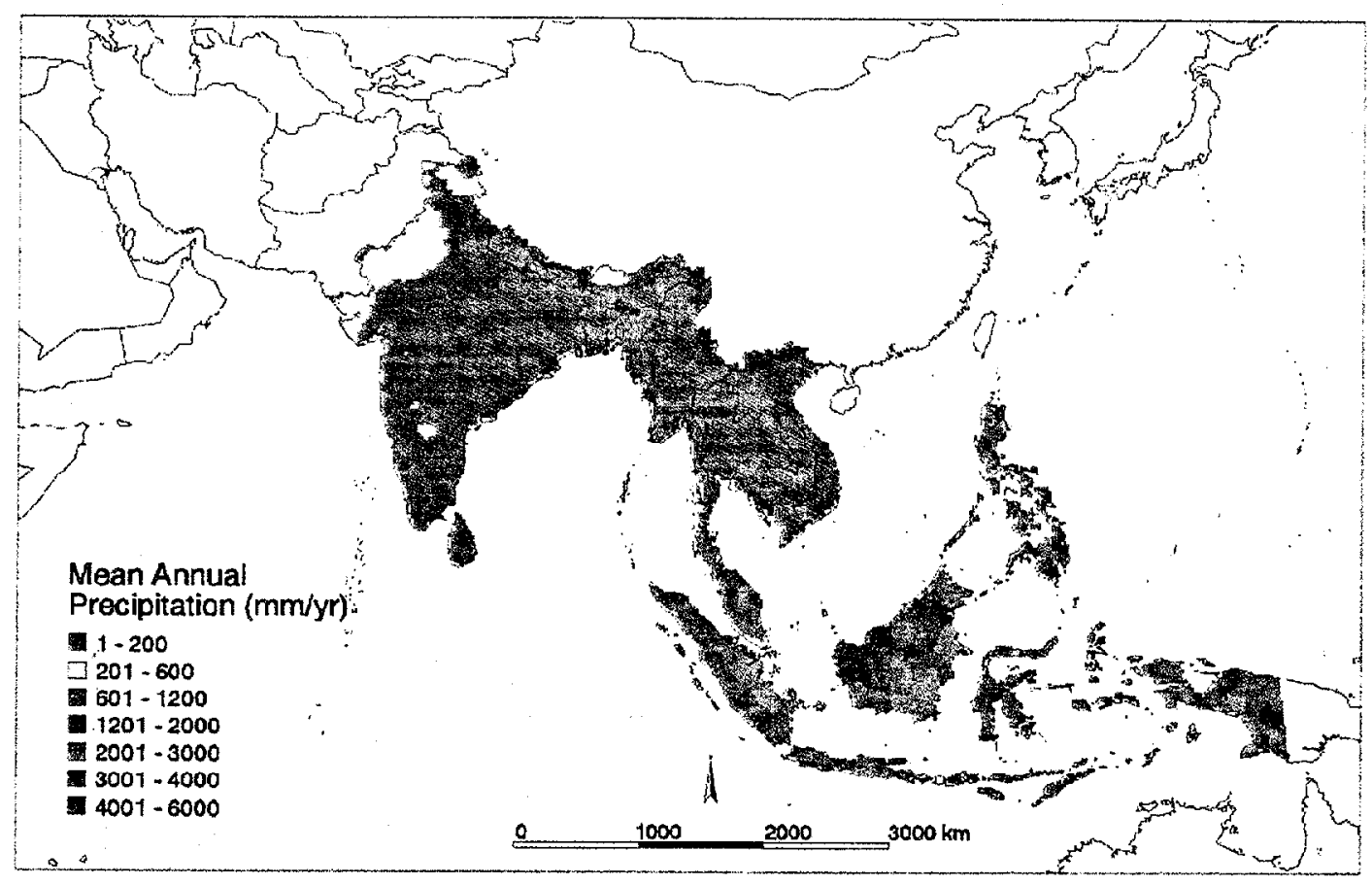

Fig. 5. Mean annual precipitation for the study area, displayed with 0.25-degree resolution. 


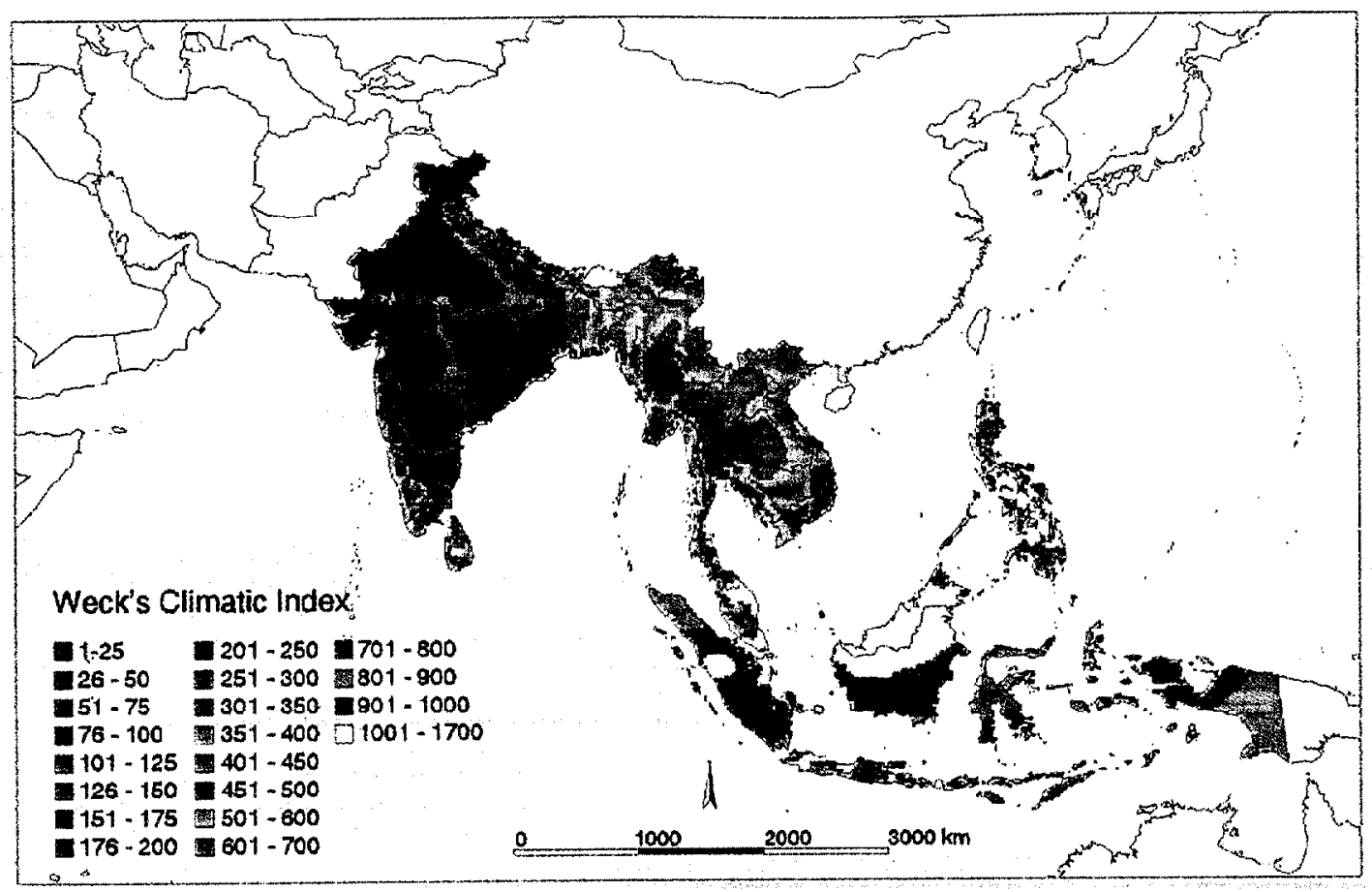

Fig. 6. Weck's Climatic Index for the study area, displayed with 0.25-degree resolution.

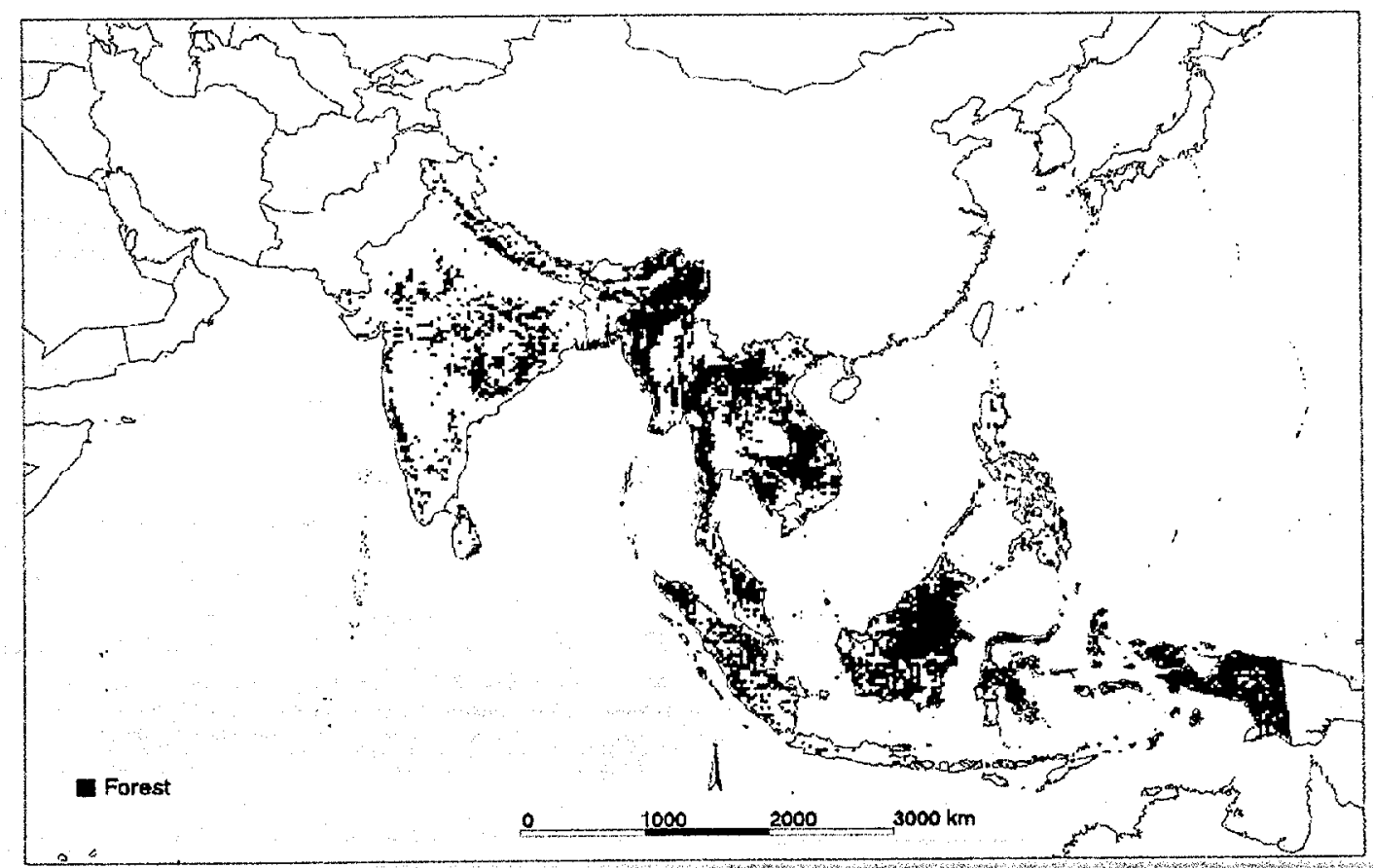

Fig. 7. Forest/non-forest classification of the study area, displayed with 0.25 -degree resolution. 


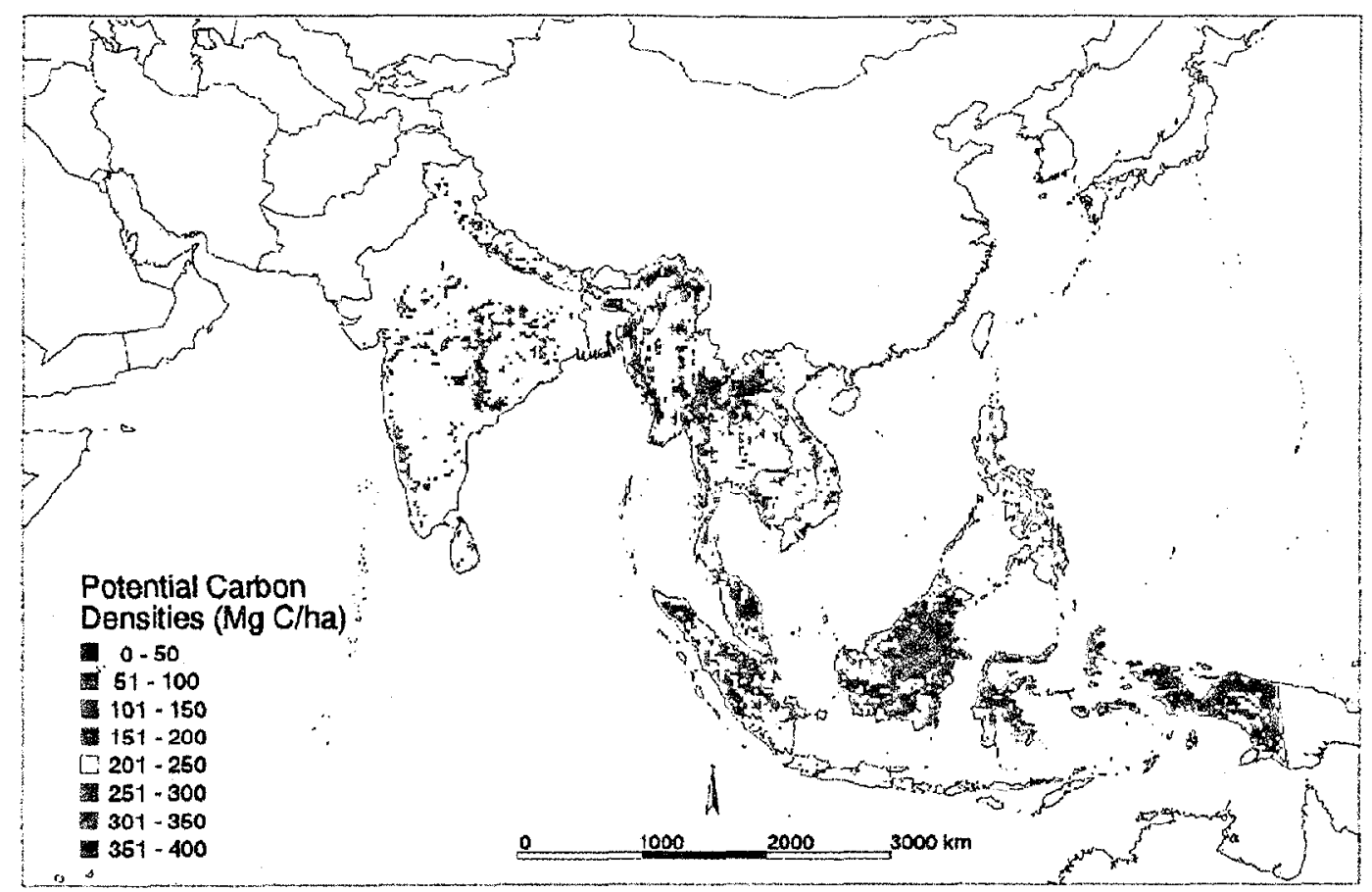

Fig. 8. Potential carbon densities in forests of the study area, displayed with 0.25-degree resolution.

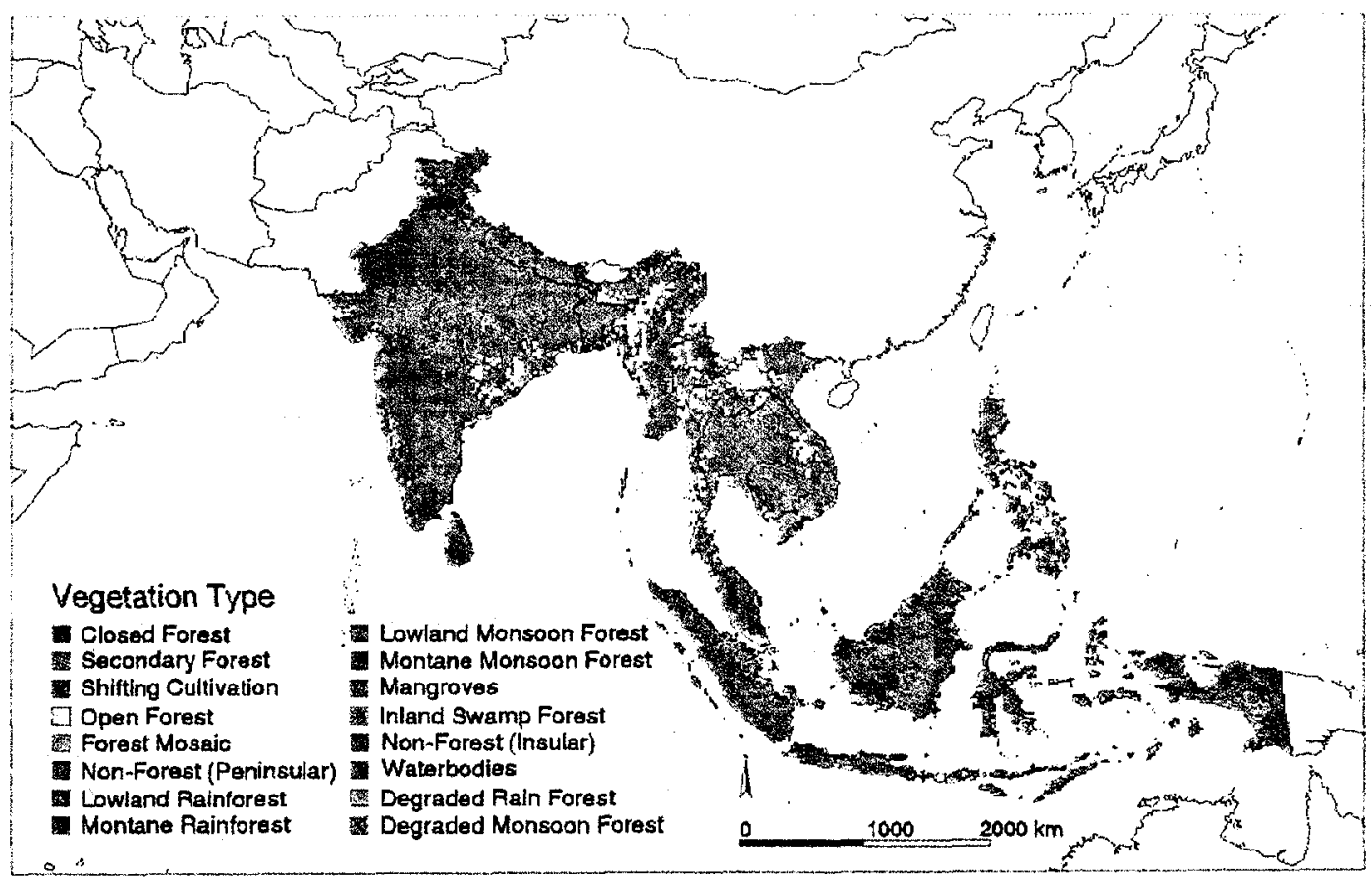

Fig. 9. Vegetation type in the study area, displayed with 0.25 -degree resolution. 


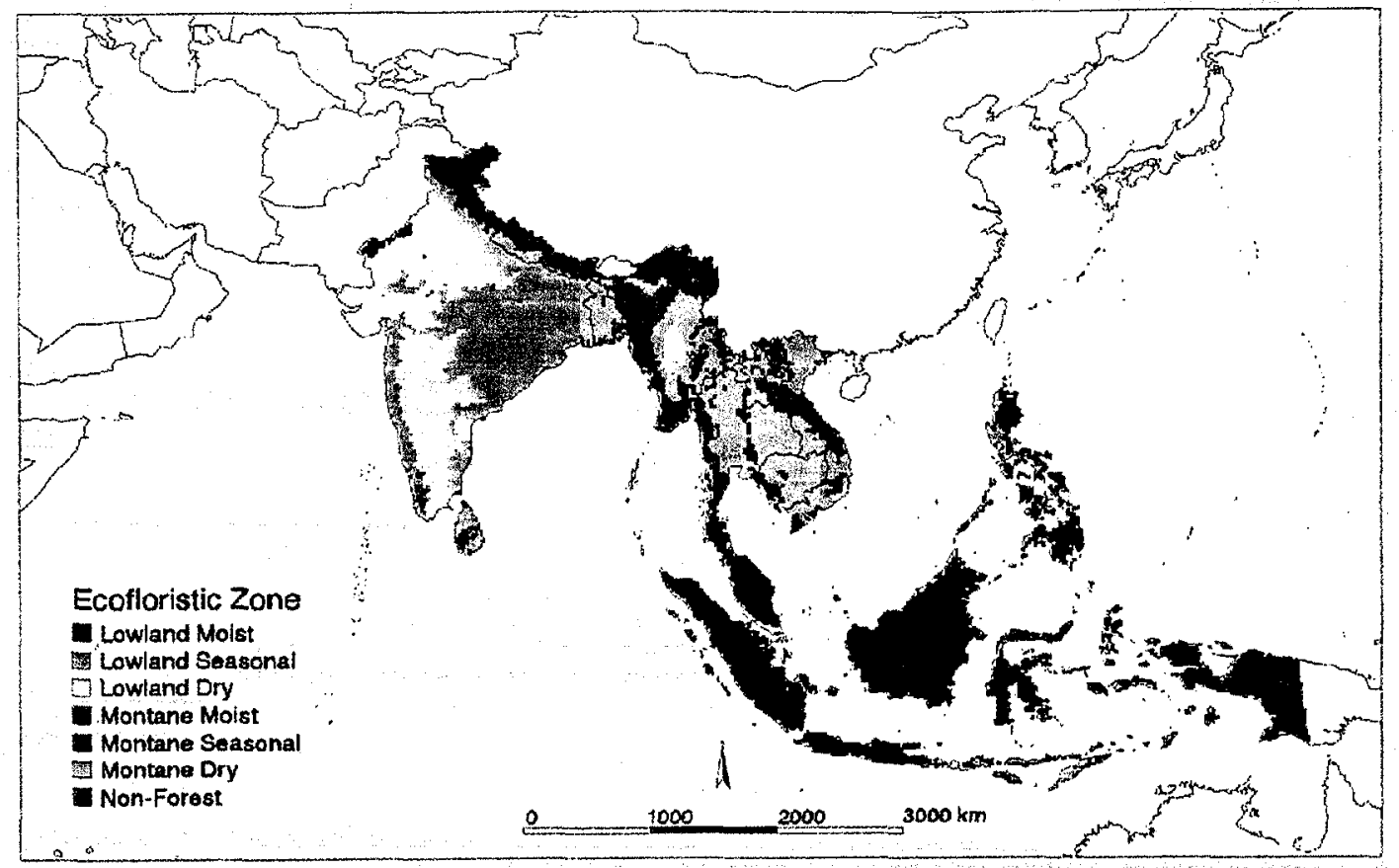

Fig. 10. Ecofloristic zone classification for the study area, displayed with 0.25 -degree resolution.

Ratios of forest degradation (from increasing population) were calculated from forest inventory data and the calculated potential biomass densities for 47 subnational units in Bangladesh, India, Malaysia (Peninsular and Insular), the Philippines, Sri Lanka, Thailand, and Vietnam. Linear regression of the forest degradation ratio versus population density (natural-log transformed) showed the effect of population density on the forest degradation ratio to be greatest in dry, followed by seasonal, then moist, forests. The regression equations were then used in conjunction with the potential biomass carbon density, population (Fig. 11), and precipitation maps [used to delineate climatic zones: aseasonal moist ( $>2000 \mathrm{~mm} /$ year), seasonally moist (1500 to $2000 \mathrm{~mm} /$ year), and dry ( $<1500 \mathrm{~mm} /$ year)] to estimate the actual biomass carbon densities of the forests. At very high and very low population densities, default degradation ratios of 0.06 and 1.0 , respectively, were used. Population density was based on data from the FAO Demographic and Statistics Department.

Root:shoot ratios were calculated from previously published data of belowground biomass and stratified according to climate zones based on precipitation and elevation. Three climate zones were recognized: dry (<1200 mm/year for lowland), seasonal (1200 to $2000 \mathrm{~mm} /$ year for lowland and 500 to $1200 \mathrm{~mm} /$ year for montane), and moist ( $>2000 \mathrm{~mm} /$ year for lowland and $>1200 \mathrm{~mm} /$ year for montane), where lowland is defined as elevation $\leq 1000 \mathrm{~m}$ and montane as elevation $>1000 \mathrm{~m}$. Moist forests were assigned a root:shoot ratio of 0.18 ; seasonal forests, 0.10 ; and dry forests, 0.5 . These ratios were used to calculate belowground biomass from the aboveground biomass estimate for each pixel. Total biomass (Fig. 12) was calculated as the sum of the below-ground and above-ground estimates. 


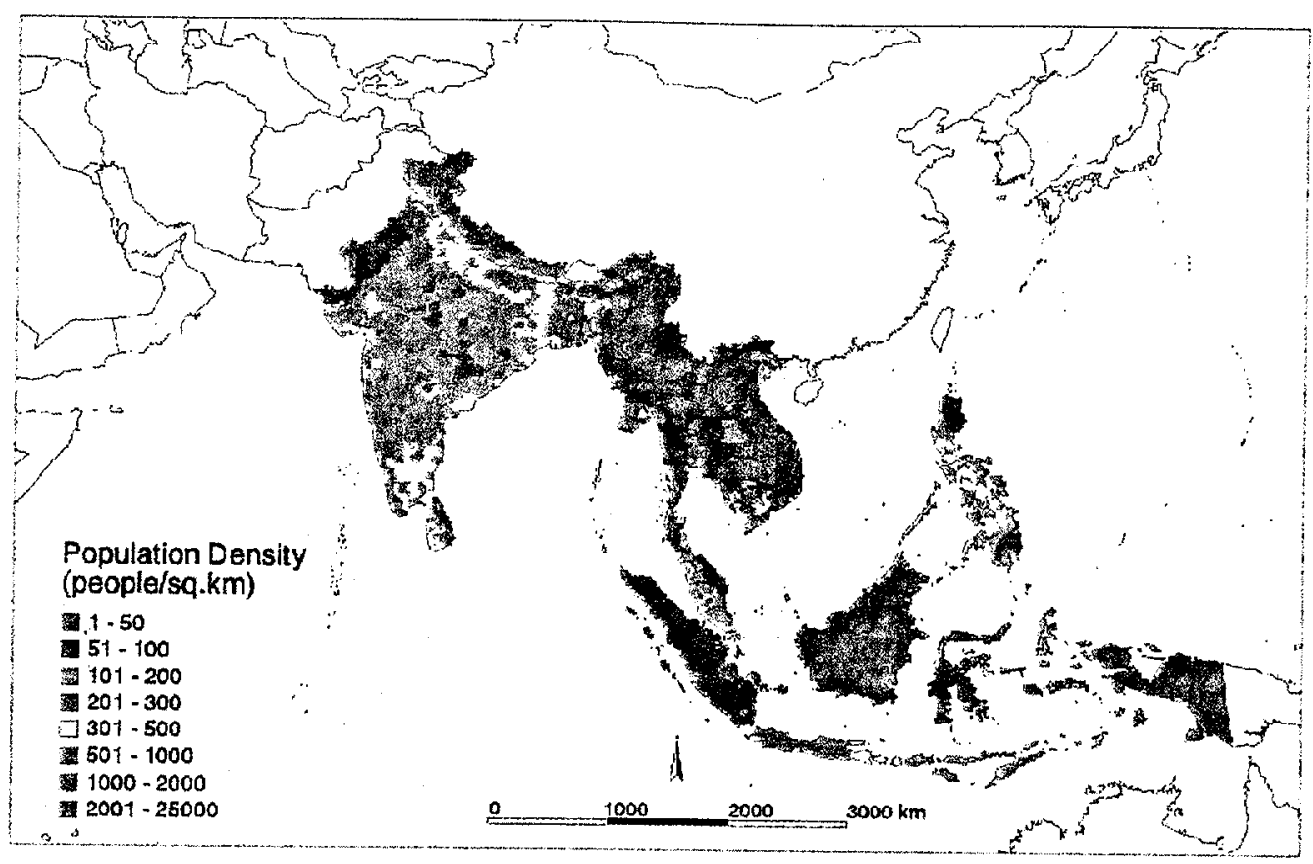

Fig. 11. Population density in the study area, displayed with 0.25 -degree resolution.

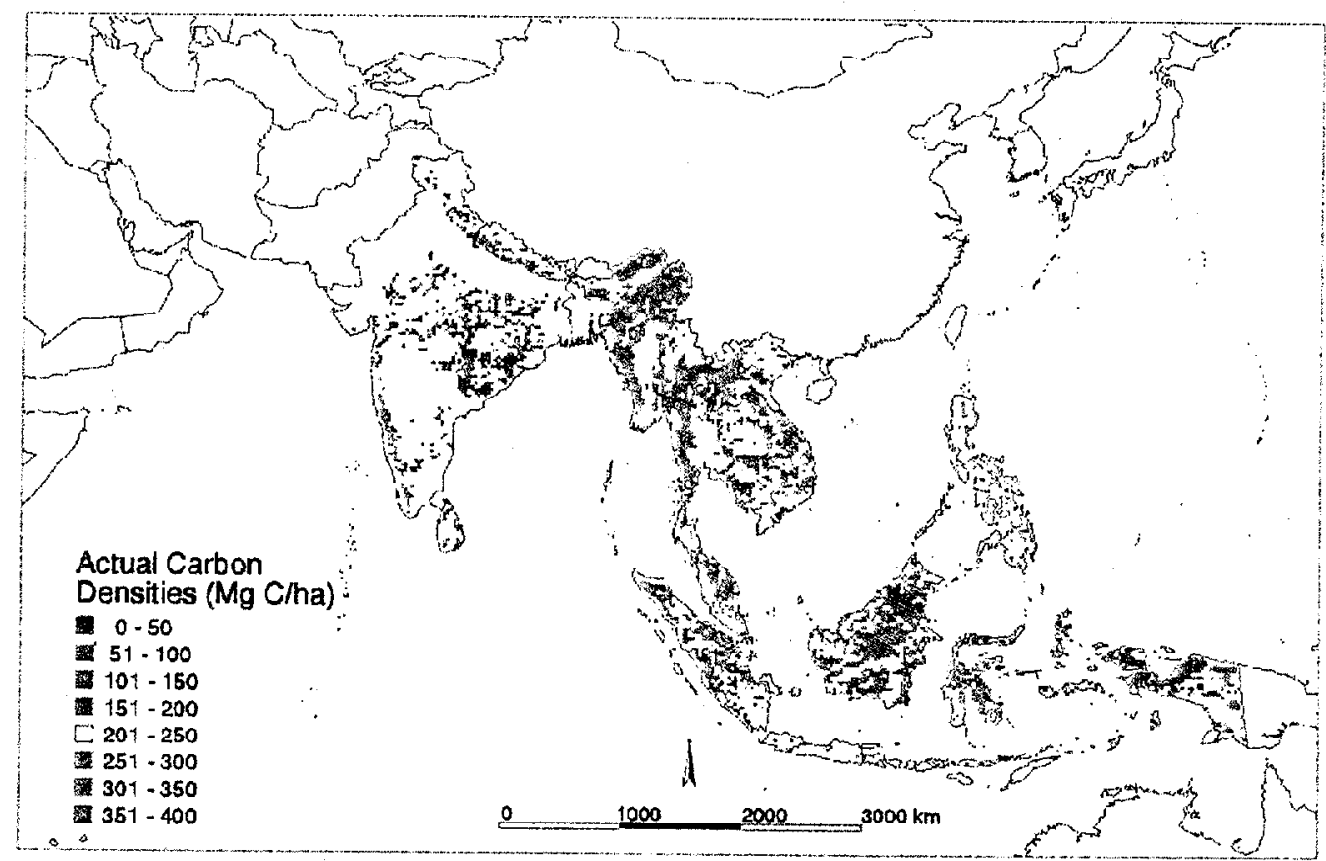

Fig. 12. Actual carbon densities in forests of the study area, displayed with 0.25 -degree resolution. 
Brown et al. (1993) compared their estimates of biomass carbon density with those of other recent assessments for the same 13-country study area. They found that estimates of biomass carbon densities derived from the FAO Tropical Forest Resource Assessment 1990 Project were about $75 \%$ of their own, and that estimates of 1980 biomass carbon density of Flint and Richards (1994) for forests and woodlands were about $65 \%$ of their own. Although differences exist between the estimates of Brown et al. and the other two studies, the three sets of values are similar in order of magnitude despite differences in methodology, input data, and time of assessment. The general similarity of the estimates provides compelling evidence that forests of tropical Asian countries have generally low biomass carbon densities; these low densities are most likely due to the long history of human use in the region.

\section{APPLICATIONS OF THE DATA}

The maps generated from the these data lend themselves to comparisons with, for example, spatial representations of land-use changes determined from satellite imagery. Consequently, uncertainties associated with carbon fluxes from tropical Southeast Asia can be reduced, and processes in the global carbon cycle (e.g., forest clearing, degradation, and regrowth) can be better quantified.

\section{DATA LIMITATIONS AND RESTRICTIONS}

The biomass estimates are limited to trees with a diameter of at least $10 \mathrm{~cm}(5 \mathrm{~cm}$ in more open forests); this would result in a slight underestimate (less than 5\%) of aboveground biomass in closed forests and an unknown amount of underestimate in open forests; the estimates also exclude litter (Brown et al. 1993). Brown et al. (1993) compared their model-derived biomass carbon density estimates with values from forest inventories. They report that their model tended to produce slight overestimates: $<5 \%$ for carbon densities of $<250 \mathrm{Mg} / \mathrm{ha}$ and $\leqslant 8 \%$ for carbon densities of $250-400 \mathrm{Mg} / \mathrm{ha}$.

The estimates provided in this numeric data package also exclude soil carbon, although Brown et al. (1993) describe the estimation of soil carbon for tropical Southeast Asia.

Brown et al. (1993) evaluated the errors in estimates of carbon densities from both methodology and data limitations. In general, they caution that, while general patterns would be reliable, carbon densities cannot be precisely located to the level of an individual pixel. The original vegetation and soil maps showed insufficient detail and might not always have been fully accurate. The precipitation, Weck's Climatic Index, and population maps were generated from point data, although interpolation error from these types of data was minimized by using a two-dimensional interpolation method and by comparing results with other maps. Potential error in weighting schemes was minimized by developing varying-width classes for each of the input variables. Omitting the effects of roads, shifting cultivation, and the differentiation between broadleaf and 
conifer species was considered acceptable, given the scale of the final maps. Correlation between population density and the calculated forest degradation index was low for some regions. New information on forest inventories can alleviate these uncertainties. It must also be noted that understory and fine and coarse litter were not included in the total carbon estimates; correction for this omission could add another 20 to $30 \%$ to the estimates of total biomass carbon density. Explicit accounting of large-scale disturbances was also not included. As new data become available, the same basic methodology for calculating carbon densities in biomass and soils can be readily applied, differences analyzed, and uncertainties further reduced (Brown et al. 1993, Iverson et al.1994).

The gridded database described in this numeric data package defines tropical Southeast Asia as originating at $-5879340.56205 \mathrm{~m}$ longitude (44.25875 degrees), $-1221655.95152 \mathrm{~m}$ latitude ( -16.52954 degrees) and extending to $3863159.43795 \mathrm{~m}$ longitude (149.50875 degrees), $4808344.04848 \mathrm{~m}$ latitude (42.97046 degrees). Data are provided for the following 13 countries: Bangladesh, Brunei, Cambodia (Campuchea), India, Indonesia, Laos, Malaysia [Peninsular (Malaya) and Insular (Sabah, also known as North Borneo, and Sarawak)], Myanmar (Burma), Nepal, the Philippines, Sri Lanka, Thailand, and Vietnam. The country boundary information was originally received from the contributors in vector format as continental and insular polygon coverages. The source polygons contained boundaries for fifteen countries in Asia, including the 13 aforementioned countries, as well as Pakistan and Papua New Guinea. For distribution purposes, the polygon data were joined together into single polygon coverage and then converted to a grid. As a result of this rasterization process, a few grid cells are defined as Pakistan or Papua New Guinea although they contain no real data. Furthermore, the gridded country boundaries within this database should not be used to define countries for other datasets, because the rasterization process produces generalized boundary lines.

\section{QUALITY-ASSURANCE CHECKS AND DATA-PROCESSING ACTIVITIES PERFORMED BY CDIAC}

An important part of the data packaging process at CDIAC involves the quality assurance (QA) of data before distribution. To guarantee data of the highest possible quality, CDIAC performs extensive QA checks, examining the data for completeness, reasonableness, and accuracy.

The data as obtained from the contributors consisted of 17 ARC/INFO-exported integer grids with a pixel size of approximately $3.75 \mathrm{~km}$ x $3.75 \mathrm{~km}$. Actual and potential carbon densities ( $\mathrm{Mg} \mathrm{C/ha),} \mathrm{as} \mathrm{well} \mathrm{as} \mathrm{ecofloristic} \mathrm{zone} \mathrm{and} \mathrm{vegetation} \mathrm{classification,} \mathrm{were} \mathrm{provided} \mathrm{individually}$ for continental and insular Southeast Asia. Separate country boundaries were provided for insular and continental Southeast Asia. These ten grids were transformed into an Albers Projection, but with a unique set of projection parameters for continental and insular Southeast Asia. Population density, mean annual precipitation, elevation, slope, soil texture, forest/non-forest designation, and Weck's Climatic Index data were assembled collectively for all of Southeast Asia. These 
seven grids were not projected (i.e., they can be referred to as being in a "geographic projection").

For distribution purposes the continental and insular data were combined into common grids. The following methodology was used:

1. Each of the 17 grids originally received from the contributors was re-projected into an Albers Projection with a cell size of $3750 \mathrm{~m}$ by using the following parameters:

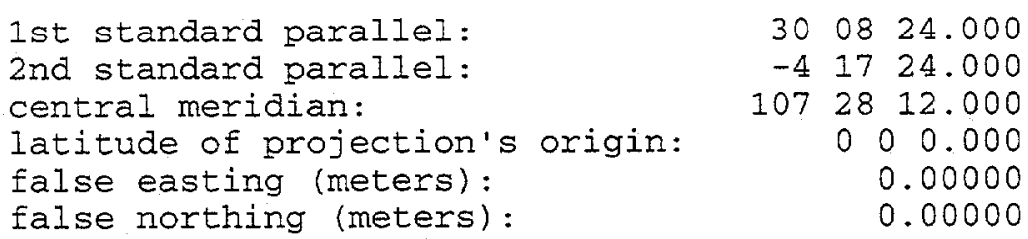

2. Each of the 17 newly projected grids was assigned a missing-value indicator of -9999 .

3. The value attribute tables for the continental and insular grids were reviewed for consistency and redundancy. Numeric data values were re-assigned as necessary.

4. The population grid was designated as a base grid because it included the combined spatial extent of real data contained in each of the 17 grids.

5. The continental grids for actual carbon density, potential carbon density, ecofloristic zone, vegetation code, and country name were combined with their corresponding insular grids and the base grid by using the ARC/NFO GRID command COMBINE.

6. The seven remaining grids were reformatted to match the extent of the base grid. This was accomplished by using the ARC/INFO GRID command COMBINE with the base grid.

Performing these six steps resulted in 12 grids with identical parameters. The 12 grids became the core data layers used to prepare the 37 data files included in this numeric data package.

The first file is merely a flat ASCII text file containing a copy of this documentation. Ten of the 37 files are exported ARC/TNFO integer grids, five with $3.75-\mathrm{km}$ pixel size and five with 0.25-degree pixel size.

The 3.75-km exported ARC/INFO grids included within this numeric data package were generated by using the ARC/INFO GRID command COMBINE and were grouped as follows:

1. Actual and potential carbon were combined into a common grid called BIOMASS. 
2. Mean annual precipitation and Weck's Climatic Index were combined into a common grid called CLIMATE.

3. Population and country were combined into a common demographic grid called DEMOG.

4. Slope, soil texture, and elevation were grouped into a common landform grid called LAND.

5. Forest designation, ecofloristic zone, and vegetation index were grouped into a common vegetation grid called VEGT.

Resampling is the process of determining values for grid cells that are geometrically transformed from a source grid into a grid of a different spatial resolution. ARC/INFO GRID offers three resampling techniques: nearest neighbor assignment, bilinear interpolation, and cubic convolution. The nearest neighbor assignment process identifies the input grid cell closest to the output grid-cell center and assigns this value to the entire output grid cell. The bilinear interpolation method of resampling identifies the four nearest input cell centers surrounding the output grid-cell center, then calculates a weighted mean of those values, and assigns the mean to the output grid-cell center. Cubic convolution is a computationally intensive interpolation method that fits a cubic polynomial surface to a $4 \times 4$ (16-pixel) neighborhood of cells to produce a smooth resultant from a distance-weighted mean. The mean and variance of the output distribution match the input distribution; however, the range of data values may be altered as a result of this process of smoothing the data.

The online documentation for ARC/INFO Version 7.2.1 offers the following guidance on resampling methods. Nearest neighbor is the preferred resampling method for categorical data because it does not alter the value of the input cells. It should be used for nominal or ordinal data where each value represents a class of data values rather than discrete data values. Bilinear interpolation is recommended for continuous surfaces because a known point or phenomenon determines the assigned value (e.g., elevation, and slope). Cubic convolution tends to smooth the data more than bilinear interpolation because of the smooth curves used as well as the larger number of points evaluated. Cubic convolution is the best method when total yields need to be determined (e.g., total $\mathrm{CO}_{2}$ emissions per country). All three techniques can be applied to continuous data, with nearest neighbor producing the most blocky output, and cubic convolution, the smoothest. However, neither bilinear interpolation nor cubic convolution should be used to resample categorical data.

The 0.25-degree ARC/INFO exported integer grids were generated as follows:

1. Each of the five 3.75-km grids was unprojected (i.e., re-projected from an Albers into a geographic projection).

2. Missing data values were changed from -9999 to "NO DATA" by using the ARC/INFO GRID SELECT command for resampling purposes. 
3. Nearest neighbor, bilinear interpolation, and cubic convolution algorithms were each used to resample actual and potential carbon biomass estimates in the BIOMASS grid to a 0.25-degree resolution.

4. The products of the resampled data were then projected back to Albers and summed. Based on a comparison of the following actual and potential biomass carbon estimates with values published by Brown et al. (1993), the cubic convolution method of resampling was used to produce the 0.25 -degree biomass grid in this numeric data package.

\begin{tabular}{lrr} 
Resampling method & Actual carbon $(\mathrm{Pg})$ & Potential carbon $(\mathrm{Pg})$ \\
\hline & & \\
Nearest neighbor & 41.7256 & 73.8159 \\
Bilinear interpolation & 41.7286 & 73.8847 \\
Cubic convolution & 41.7583 & 73.9194
\end{tabular}

5. The remaining four grids were resampled by using the nearest neighbor assignment method because each grid contained only categorical data.

6. The resulting five 0.25-degree grids (i.e., BIOMASSX, CLIMATEX, DEMOGX, LANDX, and VEGTX) have attributes comparable, but not identical, to those found in the $3.75-\mathrm{km}$ grids in this numeric data package.

Table 1 displays the data ranges for the variables in each of the ten ARC/INFO GRIDS to illustrate the redistribution of the data after the resampling process. 
Table 1. Redistribution of the data as a result of the resampling process

\begin{tabular}{|c|c|c|c|c|c|}
\hline $\begin{array}{l}\text { Variable } \\
\text { name }\end{array}$ & $\begin{array}{r}\text { Number of } \\
\text { unique values }\end{array}$ & Minimum & Maximum & Cell size & Grid name \\
\hline $\mathrm{AC}$ & 281 & 7 & 383 & $3.75 \mathrm{~km}$ & BIOMASS \\
\hline $\mathrm{AC}$ & 279 & 7 & 336 & 0.25 degree & BIOMASSX \\
\hline PC & 30 & 14 & 393 & $3.75 \mathrm{~km}$ & BIOMASS \\
\hline PC & 288 & 43 & 402 & 0.25 degree & BIOMASSX \\
\hline CLIMI & 20 & 1 & 20 & $3.75 \mathrm{~km}$ & CLIMATE \\
\hline CLIMI & 20 & 1 & 20 & 0.25 degree & CLIMATEX \\
\hline PRECIP & 13 & 1 & 13 & $3.75 \mathrm{~km}$ & CLIMATE \\
\hline PRECIP & 13 & 1 & 13 & 0.25 degree & CLIMATEX \\
\hline POP & 14 & 1 & 14 & $3.75 \mathrm{~km}$ & DEMOG \\
\hline POP & 14 & 1 & 14 & 0.25 degree & DEMOGX \\
\hline CNTRY & 16 & 1 & 16 & $3.75 \mathrm{~km}$ & DEMOG \\
\hline CNTRY & 16 & 1 & 16 & 0.25 degree & DEMOGX \\
\hline SLOPE & 6 & 1 & 6 & $3.75 \mathrm{~km}$ & LAND \\
\hline SLOPE & 6 & 1 & 6 & 0.25 degree & LANDX \\
\hline ELEV & 10 & 1 & 10 & $3.75 \mathrm{~km}$ & LAND \\
\hline ELEV & 10 & 1 & 10 & 0.25 degree & LANDX \\
\hline SOILT & 6 & 1 & 6 & $3.75 \mathrm{~km}$ & LAND \\
\hline SOILT & 6 & 1 & 6 & 0.25 degree & LANDX \\
\hline FOREST & 2 & 1 & 2 & $3.75 \mathrm{~km}$ & VEGT \\
\hline FOREST & 2 & 1 & 2 & 0.25 degree & VEGTX \\
\hline $\mathrm{EFZ}$ & 6 & 2 & 9 & $3.75 \mathrm{~km}$ & VEGT \\
\hline $\mathrm{EFZ}$ & 6 & 2 & 9 & 0.25 degree & VEGTX \\
\hline VEG & 16 & 1 & 20 & $3.75 \mathrm{~km}$ & VEGT \\
\hline VEG & 16 & 1 & 20 & 0.25 degree & VEGTX \\
\hline
\end{tabular}


The cubic convolution method of resampling was used to transfer the data values of $\mathrm{AC}$ and $\mathrm{PC}$ in the BIOMASS $(3.75-\mathrm{km})$ grid to the BIOMASSX (0.25-degree) grid. The data for AC in the $3.75-\mathrm{km}$ grid range from 7 to 383 , with 281 unique data values. After the resampling, the data for $\mathrm{AC}$ in the BIOMASSX (0.25-degree) grid ranged from 7 to 336 , with 279 unique data values. The data for PC in the BIOMASS (3.75-km) grid ranged from 14 to 393 , with 30 unique data values. After the resampling, they ranged from 43 to 402 , with 288 unique data values in the BIOMASSX (0.25-degree) grid.

The nearest neighbor method of resampling was used to transfer the data values of CLIMI, PRECIP, POP, CNTRY, SLOPE, ELEV, SOILT, FOREST, EFZ, and VEG in the remaining 3.75 -km grids (CLIMATE, DEMOG, LAND, and VEGT) to the 0.25-degree grids (CLIMATEX, DEMOGX, LANDX, and VEGTX). Note that the data range and number of unique data values did not change for these variables.

Twenty-four of the 26 remaining ASCII files were generated directly from the 10 ARC/INFO GRIDS (five $3.75-\mathrm{km}$ grids and five 0.25 -degree grids) by using the GRIDASCII command. The GRIDASCII command produces raster-based data files that can be used by most GIS software packages (and read by non-GIS software packages, as well). Each file contains $R$ lines (where $R=$ the number of rows in the grid + six header lines). Lines 1 through 6 contain the following values: the number of columns in the grid (line 1), the number of rows in the grid (line 2), the lower left-hand $x$ (longitude) coordinate (line 3), the lower left-hand $y$ (latitude) coordinate (line 4), the grid-cell size (line 5), and a definition of the grid's no-data value (line 6). The remaining lines in the file represent individual columns of data in the grid. For example, if there are 3066 columns and 1736 rows of data, there would be 1743 lines in the file. Lines 1 through 6 would contain the aforementioned header information, while lines 7 to 1743 would contain 3066 data values, each separated by a single space. Table 2 shows the arguments used with the GRIDASCII syntax to produce the 12 ASCII data files from the $3.75-\mathrm{km}$ data and the 12 ASCII data files from the 0.25-degree data. 
Table 2. GRIDASCI syntax used to produce the ASCI data files

\begin{tabular}{|c|c|c|c|}
\hline Grid name & Output file name & Variable name & Variable description \\
\hline BIOMASS & ac.dat & $\mathrm{AC}$ & Actual biomass carbon in $\mathrm{Mg} \mathrm{C} / \mathrm{ha}$ \\
\hline BIOMASS & pc.dat & $\mathrm{PC}$ & Potential biomass carbon in $\mathrm{Mg} \mathrm{C} / \mathrm{ha}$ \\
\hline CLIMATE & climi.dat & CLIMI & Weck's Climatic Index code \\
\hline CLIMATE & precip.dat & PRECIP & Mean annual precipitation code \\
\hline DEMOG & pop.dat & POP & Population density code \\
\hline DEMOG & cntry.dat & CNTRY & Country code \\
\hline LAND & slope.dat & SLOPE & Slope code \\
\hline LAND & elev.dat & ELEV & Mean elevation code \\
\hline LAND & soilt.dat & SOILT & Soil texture code \\
\hline VEGT & forest.dat & FOREST & Forest or non-forest code \\
\hline VEGT & efz.dat & $\mathrm{EFZ}$ & Ecofloristic zone code \\
\hline VEGT & veg.dat & VEG & Vegetation code \\
\hline BIOMASSX & acx.dat & $\mathrm{AC}$ & Actual biomass carbon in $\mathrm{Mg}$ C/ha \\
\hline BIOMASSX & pcx.dat & $\mathrm{PC}$ & Potential biomass carbon in $\mathrm{Mg} \mathrm{C} / \mathrm{ha}$ \\
\hline CLIMATEX & climix.dat & CLIMI & Weck's Climatic Index code \\
\hline CLIMATEX & precipx.dat & PRECIP & Mean annual precipitation code \\
\hline DEMOGX & popx.dat & POP & Population density code \\
\hline DEMOGX & cntryx.dat & CNTRY & Country code \\
\hline LANDX & slopex.dat & SLOPE & Slope code \\
\hline LANDX & elevx.dat & ELEV & Mean elevation code \\
\hline LANDX & soiltx.dat & SOILT & Soil texture code \\
\hline VEGTX & forestx.dat & FOREST & Forest or non-forest code \\
\hline VEGTX & efzx.dat & EFZ & Ecofloristic zone code \\
\hline VEGTX & vegx.dat & VEG & Vegetation code \\
\hline
\end{tabular}


The remaining two generic ASCII files with longitude and latitude $(x, y)$ coordinates were produced as follows:

1. A point coverage was generated from the BIOMASS grid by using the ARC/INFO GRIDPOINT command.

2. The ARCINFO PROJECT command was used to project the meter coordinates into decimal degrees.

3. The output coverage from step 2 was ungenerated to produce an ASCII file containing a gridcell id number, longitude, and latitude for each of the 4,177,584 grid-cell centers.

4. The 12 ASCII files produced by the GRIDASCII command for the $3.75-\mathrm{km}$ data were then merged, one file at a time, with the file produced in step 3.

5. The result of steps 1 through 4 is a file called se_asia.dat with 4,177,584 records containing the following variables: grid-cell identification number, longitude in decimal degrees of the centerpoint of each grid cell, latitude in decimal degrees of the centerpoint of each grid cell, actual biomass carbon, potential biomass carbon, precipitation, population, country, slope, soil texture, forest designation, ecofloristic zone, and vegetation index.

6. A point coverage was generated from the BIOMASSX grid by using the ARC/NFO GRIDPOINT command.

7. The 12 ASCII files produced by the GRIDASCII command for the 0.25 -degree data were then merged, one file at a time, with the files produced in step 6. Note that, because these data are provided in an unprojected format, there was no need to use a projection step to assemble these data for distribution.

8. Steps 6 and 7 resulted in a file called se_asiax.dat containing 100,198 records, with the same variables listed in step 5 .

Actual and potential biomass were each totaled for tropical Southeast Asia from the data sets included with this numeric data package, for comparison with the totals published by Brown et al. (1993). For each data set, the number of pixels with a specific carbon density was multiplied by the carbon density then multiplied by the pixel area to yield total carbon; finally, this product was summed for all carbon densities. For tropical Southeast Asia, estimated total biomass is $42.1 \mathrm{Pg} \mathrm{C}$ actual and 73.6 $\mathrm{Pg} \mathrm{C}$ potential. The same totals were calculated from the 0.25 -degree gridded data to be $41.8 \mathrm{Pg} \mathrm{C}$ actual and $73.9 \mathrm{Pg} \mathrm{C}$ potential. These totals agree with the corresponding values of $42 \mathrm{Pg} \mathrm{C}$ actual and $74 \mathrm{Pg} \mathrm{C}$ potential reported in Brown et al. (1993), verifying that overall the database included with this numeric data package reflects the data used by the authors in their publication. 
As an additional check, the actual biomass carbon density estimates for 1980 in this database can be compared with the carbon content data in Table 5 of NDP-046 (Richards and Flint 1994) for the same year. The 1980 total carbon in forest cover is estimated by Richards and Flint (1994) to be $23.95 \mathrm{Pg} \mathrm{C}$ in contrast with $42 \mathrm{Pg} \mathrm{C}$ estimated herein. This level of difference is similar to the differences in carbon densities observed in the estimates of Brown et al. (1993) and of Flint and Richards (1994). In addition to the methodological and data-source differences mentioned in Section 3, it must be noted that Richards and Flint (1994), but not Brown et al. (1993), include Singapore, whereas the converse is true for Nepal; furthermore, there are differences between the two databases in terms of the estimated area covered by forests.

\section{REFERENCES}

Brown, S., L. R. Iverson, A. Prasad, and D. Liu. 1993. Geographical distributions of carbon in biomass and soils of tropical Asian forests. Geocarto International 4:45-59.

Brown, S., G. Gaston, and R. C. Daniels. 1996. Tropical Africa: Land use, biomass, and carbon estimates for 1980. ORNL/CDIAC-92, NDP-055. Carbon Dioxide Information Analysis Center, Oak Ridge National Laboratory, U.S. Department of Energy, Oak Ridge, Tennessee.

Flint, E. P., and J. F. Richards. 1994. Trends in carbon content of vegetation in South and Southeast Asia associated with changes in land use, pp. 201-299. In V. Dale (ed.), Effects of Land-Use Change on Atmospheric $\mathrm{CO}_{2}$ Concentrations: South and Southeast Asia as a Case Study. Springer-Verlag, New York.

Houghton, R. A., and J. L. Hackler. 1995. Continental scale estimates of the biotic carbon flux from land cover change: 1850 to 1980. ORNL/CDIAC-79, NDP-050. Carbon Dioxide Information Analysis Center, Oak Ridge National Laboratory, U.S. Department of Energy, Oak Ridge, Tennessee.

Iverson, L., S. Brown, A. Prasad, H. Mitasova, A. J. R. Gillespie, and A. E. Lugo. 1994. Use of GIS for estimating potential and actual forest biomass for continental South and Southeast Asia, pp. 67-116. In V. Dale (ed.), Effects of Land-Use Change on Atmospheric $\mathrm{CO}_{2}$ Concentrations: South and Southeast Asia as a Case Study. Springer-Verlag, New York.

Olson, J. S., J. A. Watts, and L. J. Allison. 1985. Major world ecosystem complexes ranked by carbon in live vegetation: A database. NDP-017. Carbon Dioxide Information Analysis Center, Oak Ridge National Laboratory, U.S. Department of Energy, Oak Ridge, Tennessee.

Richards, J. F., and E. P. Flint. 1994. Historic land use and carbon estimates for South and Southeast Asia. ORNL/CDIAC-61, NDP-064. Carbon Dioxide Information Analysis Center, Oak Ridge National Laboratory, U.S. Department of Energy, Oak Ridge, Tennessee. 
Risser, P. G., and L. R. Iverson. 1988. Geographic information systems and natural resource issues at the state level, pp. 231-239. In D. B. Botkin, M. E. Casswell, J. E. Estes, and A. A. Orio (eds.), Our Role in Changing the Global Environment: What Can We Do About Large Scale Environmental Issues? Academic Press, New York.

Weck, J. 1970. An improved CVP-index for the delimitation of the potential productivity zones of forest lands of India. Indian Forester 96:565-572.

\section{HOW TO OBTAIN THE DATA AND DOCUMENTATION}

This database (NDP-068) is available free of charge from CDIAC. The files are available from CDIAC's Web site (http://cdiac.esd.ornl.gov) or from CDIAC's anonymous FTP (file transfer protocol) area (cdiac.esd.ornl.gov) as follows:

1. FTP to cdiac.esd.ornl.gov (128.219.24.36).

2. Enter "ftp" as the user id.

3. Enter your electronic mail address as the password (e.g., fred@zulu.org).

4. Change to the directory "pub/ndp068" (i.e., use the command "cd pub/ndp068").

5. Set ftp to get ASCII files by using the ftp "ascii" command.

6. Retrieve the ASCII database documentation file by using the ftp "get ndp068.txt" command, and retrieve the ASCII data files by using the ftp "mget *.dat" command.

7. Set ftp to get *.e00 data files by using the ftp "binary" command.

8. Retrieve the *.e00 data files by using the ftp "mget *.e00" command.

9. Exit the system by using the ftp "quit" command.

Uncompress the files on your computer, if they are obtained in compressed format.

For non-Internet data acquisitions (e.g., floppy diskette or compact disk) or for additional information, contact:

Carbon Dioxide Information Analysis Center

Oak Ridge National Laboratory

P.O. Box 2008

Oak Ridge, Tennessee 37831-6335, U.S.A.

Telephone: 1-865-574-3645

Telefax: 1-865-574-2232

E-mail: cdiac@ornl.gov 


\section{LISTING OF FILES PROVIDED}

This database consists of 37 files: This documentation file (ndp068.txt, File 1), 10 exported ARC/INFO integer grid files, and 26 ASCII data files (Table 3). Five of the 10 exported ARC/INFO grid files have a pixel size of $3.75 \mathrm{~km}$ by $3.75 \mathrm{~km}$, whereas the other five have a pixel size of 0.25 degrees by 0.25 degrees. Each core data layer in this database was also grouped into one of five thematic grids (see Sect. 4). The $3.75-\mathrm{km}$ data were aggregated to a resolution of 0.25 degrees; the data at the two levels of resolution contain identical attributes. Each grid when imported into ARC/INFO is an integer grid and contains a value attribute table (vat) and a statistics table (sta). Except for the biomass carbon measures, each grid contains data classes identified by a numeric value code and defined by a character description of the class.

Twenty-four of the 26 ASCII data files were generated by using the ARC/INFO GRIDASCII command. As such, these files can be used with or without ARC/INFO software and can be used by raster or vector GIS software packages as well as non-GIS software packages. These 24 files each represent one data item and, when used as a GRID in ARC/INFO, contain the same information found in the $10 \mathrm{ARC} / \mathrm{INFO}$ export grids in this numeric data package. The two remaining ASCII data files are aggregates of all the data within this database in ASCII format, one at a spatial resolution of $3.75 \mathrm{~km}$ and the other at 0.25 degree. Table 3 describes the files provided in this numeric data package.

Table 3. Files in this numeric data package

\begin{tabular}{|c|c|c|c|c|c|}
\hline $\begin{array}{l}\text { File } \\
\text { number }\end{array}$ & File name & $\begin{array}{l}\text { File size } \\
\text { (kbytes) }\end{array}$ & File description & $\begin{array}{l}\text { Projection } \\
\text { type }\end{array}$ & File type \\
\hline 1 & ndp068.txt & 94 & $\begin{array}{l}\text { Descriptive file (i.e., this } \\
\text { document) }\end{array}$ & $\mathrm{n} / \mathrm{a}$ & ASCII text \\
\hline 2 & Biomass.e00 & 59,468 & $\begin{array}{l}\text { Exported ARC/NFO gridded } \\
(3.75-\mathrm{km}) \text { estimates of actual } \\
\text { and potential biomass carbon }\end{array}$ & Albers & $\begin{array}{l}\text { ARC/INFO } \\
\text { export GRID }\end{array}$ \\
\hline 3 & Biomassx.e00 & 1,534 & $\begin{array}{l}\text { Exported ARC/NFO gridded } \\
(0.25 \text {-degree) estimates of } \\
\text { actual and potential biomass } \\
\text { carbon }\end{array}$ & Geographic & $\begin{array}{l}\text { ARC/INFO } \\
\text { export GRID }\end{array}$ \\
\hline 4 & ac.dat & 24,607 & $\begin{array}{l}\text { ASCII file of ungenerated } \\
\text { ARC/INFO gridded ( } 3.75- \\
\mathrm{km}) \text { estimates of actual } \\
\text { biomass carbon }\end{array}$ & Albers & $\begin{array}{l}\text { GRIDASCII } \\
\text { ASCII data } \\
\text { file }\end{array}$ \\
\hline 5 & acx.dat & 593 & $\begin{array}{l}\text { ASCI file of ungenerated } \\
\text { ARC/NFO gridded ( } 0.25- \\
\text { degree) estimates of actual } \\
\text { biomass carbon }\end{array}$ & Geographic & $\begin{array}{l}\text { GRIDASCII } \\
\text { ASCII data } \\
\text { file }\end{array}$ \\
\hline
\end{tabular}


Table 3 (continued)

\begin{tabular}{|c|c|c|c|c|c|}
\hline $\begin{array}{l}\text { File } \\
\text { number }\end{array}$ & File name & $\begin{array}{l}\text { File size } \\
\text { (kbytes) }\end{array}$ & File description & $\begin{array}{l}\text { Projection } \\
\text { type }\end{array}$ & File type \\
\hline 6 & pc.dat & 24,655 & $\begin{array}{l}\text { ASCII file of ungenerated } \\
\text { ARCINFO gridded ( } 3.75- \\
\mathrm{km} \text { ) estimates of potential } \\
\text { biomass carbon }\end{array}$ & Albers & $\begin{array}{l}\text { GRIDASCII } \\
\text { ASCII data } \\
\text { file }\end{array}$ \\
\hline 7 & pex.dat & 594 & $\begin{array}{l}\text { ASCII file of ungenerated } \\
\text { ARC/INFO gridded }(0.25- \\
\text { degree) estimates of potential } \\
\text { biomass carbon }\end{array}$ & Geographic & $\begin{array}{l}\text { GRIDASCII } \\
\text { ASCII data } \\
\text { file }\end{array}$ \\
\hline 8 & Climate.e00 & 59,382 & $\begin{array}{l}\text { Exported ARC/NFO gridded } \\
(3.75-\mathrm{km}) \text { Weck's Climatic } \\
\text { Index and mean annual } \\
\text { precipitation }\end{array}$ & Albers & $\begin{array}{l}\text { ARC/INFO } \\
\text { export GRID }\end{array}$ \\
\hline 9 & Climatex.e00 & 1,448 & $\begin{array}{l}\text { Exported ARC/NFO gridded } \\
(0.25 \text {-degree) Weck's } \\
\text { Climatic Index and mean } \\
\text { annual precipitation }\end{array}$ & Geographic & $\begin{array}{l}\text { ARC/INFO } \\
\text { export GRID }\end{array}$ \\
\hline 10 & climi.dat & 23,218 & $\begin{array}{l}\text { ASCII file of ungenerated } \\
\text { ARC/INFO gridded ( } 3.75- \\
\mathrm{km}) \text { Weck's Climatic Index }\end{array}$ & Albers & $\begin{array}{l}\text { GRIDASCII } \\
\text { ASCII data } \\
\text { file }\end{array}$ \\
\hline 11 & climix.dat & 566 & $\begin{array}{l}\text { ASCII file of ungenerated } \\
\text { ARC/INFO gridded }(0.25- \\
\text { degree) Weck's Climatic } \\
\text { Index }\end{array}$ & Geographic & $\begin{array}{l}\text { GRIDASCII } \\
\text { ASCII data } \\
\text { file }\end{array}$ \\
\hline 12 & precip.dat & 23,047 & $\begin{array}{l}\text { ASCII file of ungenerated } \\
\text { ARC/INFO gridded ( } 3.75- \\
\mathrm{km} \text { ) mean annual } \\
\text { precipitation }\end{array}$ & Albers & $\begin{array}{l}\text { GRIDASCII } \\
\text { ASCII data } \\
\text { file }\end{array}$ \\
\hline 13 & precipx.dat & 562 & $\begin{array}{l}\text { ASCII file of ungenerated } \\
\text { ARC/INFO gridded }(0.25- \\
\text { degree) mean annual } \\
\text { precipitation }\end{array}$ & Geographic & $\begin{array}{l}\text { GRIDASCII } \\
\text { ASCII data } \\
\text { file }\end{array}$ \\
\hline 14 & Demog.e00 & 59,381 & $\begin{array}{l}\text { Exported ARC/INFO gridded } \\
(3.75-\mathrm{km}) \text { population density } \\
\text { and country name }\end{array}$ & Albers & $\begin{array}{l}\text { ARC/INFO } \\
\text { export GRID }\end{array}$ \\
\hline 15 & Demogx.e00 & 1,449 & $\begin{array}{l}\text { Exported ARC/INFO gridded } \\
\text { (0.25-degree) population } \\
\text { density and country name }\end{array}$ & Geographic & $\begin{array}{l}\text { ARC/INFO } \\
\text { export GRID }\end{array}$ \\
\hline
\end{tabular}


Table 3 (continued)

\begin{tabular}{|c|c|c|c|c|c|}
\hline $\begin{array}{l}\text { File } \\
\text { number }\end{array}$ & File name & $\begin{array}{l}\text { File size } \\
\text { (kbytes) }\end{array}$ & File description & $\begin{array}{l}\text { Projection } \\
\text { type }\end{array}$ & File type \\
\hline 16 & pop.dat & 22,865 & $\begin{array}{l}\text { ASCII file of ungenerated } \\
\text { ARC/INFO gridded ( } 3.75- \\
\mathrm{km}) \text { population density }\end{array}$ & Albers & $\begin{array}{l}\text { GRIDASCII } \\
\text { ASCII data } \\
\text { file }\end{array}$ \\
\hline 17 & popx.dat & 559 & $\begin{array}{l}\text { ASCII file of ungenerated } \\
\text { ARC/INFO gridded }(0.25- \\
\text { degree) population density }\end{array}$ & Geographic & $\begin{array}{l}\text { GRIDASCII } \\
\text { ASCII data } \\
\text { file }\end{array}$ \\
\hline 18 & cntry.dat & 23,056 & $\begin{array}{l}\text { ASCII file of ungenerated } \\
\text { ARC/INFO gridded ( } 3.75- \\
\mathrm{km}) \text { country name }\end{array}$ & Albers & $\begin{array}{l}\text { GRIDASCII } \\
\text { ASCII data } \\
\text { file }\end{array}$ \\
\hline 19 & cntryx.dat & 563 & $\begin{array}{l}\text { ASCII file of ungenerated } \\
\text { ARC } / N F O \text { gridded }(0.25- \\
\text { degree }) \text { country name }\end{array}$ & Geographic & $\begin{array}{l}\text { GRIDASCII } \\
\text { ASCII data } \\
\text { file }\end{array}$ \\
\hline 20 & Land.e00 & 59,401 & $\begin{array}{l}\text { Exported ARC/INFO gridded } \\
(3.75-\mathrm{km}) \text { slope, elevation, } \\
\text { and soil texture }\end{array}$ & Albers & $\begin{array}{l}\text { ARC/INFO } \\
\text { export GRID }\end{array}$ \\
\hline 21 & Landx.e00 & 1,461 & $\begin{array}{l}\text { Exported ARC/INFO gridded } \\
(0.25 \text {-degree }) \text { slope, } \\
\text { elevation, and soil texture }\end{array}$ & Geographic & $\begin{array}{l}\text { ARC/INFO } \\
\text { export GRID }\end{array}$ \\
\hline 22 & slope.dat & 22,884 & $\begin{array}{l}\text { ASCII file of ungenerated } \\
\text { ARC/INFO gridded ( } 3.75- \\
\mathrm{km}) \text { slope }\end{array}$ & Albers & $\begin{array}{l}\text { GRIDASCII } \\
\text { ASCII data } \\
\text { file }\end{array}$ \\
\hline 23 & slopex.dat & 559 & $\begin{array}{l}\text { ASCII file of ungenerated } \\
\text { ARC/INFO gridded }(0.25- \\
\text { degree }) \text { slope }\end{array}$ & Geographic & $\begin{array}{l}\text { GRIDASCII } \\
\text { ASCII data } \\
\text { file }\end{array}$ \\
\hline 24 & elev.dat & 22,873 & $\begin{array}{l}\text { ASCII file of ungenerated } \\
\text { ARC/INFO gridded }(3.75- \\
\mathrm{km}) \text { elevation }\end{array}$ & Albers & $\begin{array}{l}\text { GRIDASCII } \\
\text { ASCII data } \\
\text { file }\end{array}$ \\
\hline 25 & elevx.dat & 559 & $\begin{array}{l}\text { ASCII file of ungenerated } \\
\text { ARC/INFO gridded }(0.25- \\
\text { degree }) \text { elevation }\end{array}$ & Geographic & $\begin{array}{l}\text { GRIDASCII } \\
\text { ASCII data } \\
\text { file }\end{array}$ \\
\hline 26 & soilt.dat & 22,884 & $\begin{array}{l}\text { ASCII file of ungenerated } \\
\text { ARC/INFO gridded ( } 3.75- \\
\mathrm{km}) \text { soil texture }\end{array}$ & Albers & $\begin{array}{l}\text { GRIDASCII } \\
\text { ASCII data } \\
\text { file }\end{array}$ \\
\hline 27 & soiltx.dat & 559 & $\begin{array}{l}\text { ASCII file of ungenerated } \\
\text { ARC/INFO gridded }(0.25- \\
\text { degree) soil texture }\end{array}$ & Geographic & $\begin{array}{l}\text { GRIDASCII } \\
\text { ASCII data } \\
\text { file }\end{array}$ \\
\hline
\end{tabular}


Table 3 (continued)

\begin{tabular}{|c|c|c|c|c|c|}
\hline $\begin{array}{l}\text { File } \\
\text { number }\end{array}$ & File name & $\begin{array}{l}\text { File size } \\
\text { (kbytes) }\end{array}$ & File description & $\begin{array}{l}\text { Projection } \\
\text { type }\end{array}$ & File type \\
\hline 28 & Vegt.e00 & 59,392 & $\begin{array}{l}\text { Exported ARC/INFO gridded } \\
(3.75-\mathrm{km}) \text { forest or } \\
\text { non-forest designation, } \\
\text { ecofloristic zone, and } \\
\text { vegetation type }\end{array}$ & Albers & $\begin{array}{l}\text { ARC/INFO } \\
\text { export GRID }\end{array}$ \\
\hline 29 & Vegtx.e00 & 1,452 & $\begin{array}{l}\text { Exported ARC/INFO gridded } \\
(0.25 \text {-degree) forest or } \\
\text { non-forest designation, } \\
\text { ecofloristic zone, and } \\
\text { vegetation type }\end{array}$ & Geographic & $\begin{array}{l}\text { ARC/INFO } \\
\text { export GRID }\end{array}$ \\
\hline 30 & forest.dat & 22,880 & $\begin{array}{l}\text { ASCII file of ungenerated } \\
\text { ARC/INFO gridded ( } 3.75- \\
\mathrm{km}) \text { forest or non-forest } \\
\text { designation }\end{array}$ & Albers & $\begin{array}{l}\text { GRIDASCII } \\
\text { ASCII data } \\
\text { file }\end{array}$ \\
\hline 31 & forestx.dat & 559 & $\begin{array}{l}\text { ASCII file of ungenerated } \\
\text { ARC/INFO gridded }(0.25- \\
\text { degree) forest or non-forest } \\
\text { designation }\end{array}$ & Geographic & $\begin{array}{l}\text { GRIDASCII } \\
\text { ASCII data } \\
\text { file }\end{array}$ \\
\hline 32 & efz.dat & 22,895 & $\begin{array}{l}\text { ASCII file of ungenerated } \\
\text { ARC/INFO gridded ( } 3.75- \\
\mathrm{km} \text { ) ecofloristic zone }\end{array}$ & Albers & $\begin{array}{l}\text { GRIDASCII } \\
\text { ASCII data } \\
\text { file }\end{array}$ \\
\hline 33 & efzx.dat & 560 & $\begin{array}{l}\text { ASCII file of ungenerated } \\
\text { ARC/INFO gridded ( } 0.25- \\
\text { degree) ecofloristic zone }\end{array}$ & Geographic & $\begin{array}{l}\text { GRIDASCII } \\
\text { ASCII data } \\
\text { file }\end{array}$ \\
\hline 34 & veg.dat & 23,037 & $\begin{array}{l}\text { ASCII file of ungenerated } \\
\text { ARC/INFO gridded ( } 3.75- \\
\mathrm{km}) \text { vegetation type }\end{array}$ & Albers & $\begin{array}{l}\text { GRIDASCII } \\
\text { ASCII data } \\
\text { file }\end{array}$ \\
\hline 35 & vegx.dat & 562 & $\begin{array}{l}\text { ASCII file of ungenerated } \\
\text { ARC/INFO gridded ( } 0.25 \text { - } \\
\text { degree) vegetation type }\end{array}$ & Geographic & $\begin{array}{l}\text { GRIDASCII } \\
\text { ASCII data } \\
\text { file }\end{array}$ \\
\hline
\end{tabular}


Table 3 (continued)

\begin{tabular}{|c|c|c|c|c|c|}
\hline $\begin{array}{l}\text { File } \\
\text { number }\end{array}$ & File name & $\begin{array}{l}\text { File size } \\
\text { (kbytes) }\end{array}$ & File description & $\begin{array}{l}\text { Projection } \\
\text { type }\end{array}$ & File type \\
\hline 36 & se_asia.dat & 407,372 & $\begin{array}{l}\text { ASCII file of gridded ( } 3.75- \\
\mathrm{km} \text { ) grid-cell identification } \\
\text { number, longitude and } \\
\text { latitude (of the centerpoint of } \\
\text { each grid cell), estimate of } \\
\text { actual biomass carbon, } \\
\text { estimate of potential biomass } \\
\text { carbon, Weck's Climatic } \\
\text { Index, mean annual } \\
\text { precipitation, population } \\
\text { density, country name, slope, } \\
\text { elevation, soil texture, forest } \\
\text { or non-forest designation, } \\
\text { ecofloristic zone, and } \\
\text { vegetation type }\end{array}$ & $\mathrm{n} / \mathrm{a}$ & $\begin{array}{l}\text { composite } \\
\text { ASCII data } \\
\text { file }\end{array}$ \\
\hline 37 & se_asiax.dat & 9,780 & $\begin{array}{l}\text { ASCII file of gridded ( } 0.25- \\
\text { degree) grid-cell } \\
\text { identification number, } \\
\text { longitude and latitude (of the } \\
\text { centerpoint of each grid cell), } \\
\text { estimate of actual biomass } \\
\text { carbon, estimate of potential } \\
\text { biomass carbon, Weck's } \\
\text { Climatic Index, mean annual } \\
\text { precipitation, population } \\
\text { density, country name, slope, } \\
\text { elevation, soil texture, forest } \\
\text { or non-forest designation, } \\
\text { ecofloristic zone, and } \\
\text { vegetation type }\end{array}$ & $\mathrm{n} / \mathrm{a}$ & $\begin{array}{l}\text { composite } \\
\text { ASCII data } \\
\text { file }\end{array}$ \\
\hline
\end{tabular}

Note: GRIDASCII is an ARC/NFO ${ }^{\mathrm{TM}}$ command that produces an ASCII file containing data for an individual gridded data layer. 


\section{DESCRIPTION OF THE DOCUMENTATION FILE}

ndp068.txt (File 1)

This file is identical to this document.

\section{DESCRIPTION, FORMAT, AND PARTIAL LISTINGS OF THE ARC/INFO GRID FILES}

Ten of the 37 files contained within this database are exported ARC/INFO grids. Each exported grid file was generated using the EXPORT command in ARC/NNFO with the 'grid' and the 'no data compression' options (e.g., EXPORT GRID BIOMASS BIOMASS NONE). Five of the exported grid files contain a pixel size of $3.75 \mathrm{~km}$, whereas the other five have a pixel size of 0.25 degrees.

The five 3.75-km ARC/TNFO export grids are named BIOMASS, CLIMATE, DEMOG, LAND, and VEGT, and the five 0.25-degree grids are called BIOMASSX, CLIMATEX, DEMOGX, LANDX, and VEGTX. Each grid has been projected into Albers with a unit base of meters by using the following parameters:

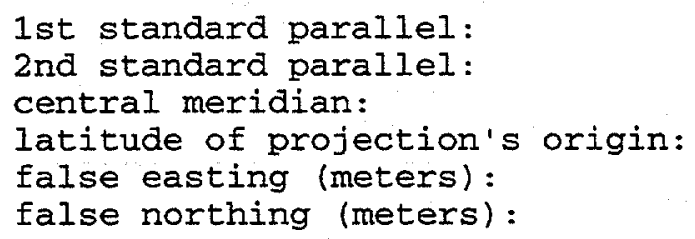

$30 \quad 08 \quad 24.000$

$\begin{array}{lll}-4 & 17 & 24.000\end{array}$

1072812.000

000.000

0.00000

0.00000

The five 3.75-km ARC/INFO grids originate at $-5879340.56205,-1221655.95152 \mathrm{~m}$ and extend to $3863159.43795,4808344.04848 \mathrm{~m}$; these values are approximately equal to an origin of 44.25875 longitude, -16.52954 latitude and an extent of 149.50875 longitude, 42.97046 latitude. There are 1608 rows and 2598 columns in each grid.

The five 0.25 -degree grids originate at 44.25875 degrees longitude, -16.52954 degrees latitude and extend to 149.50875 degrees longitude, 42.97046 degrees latitude. There are 238 rows and 421 columns in each grid.

The 3.75-km grids and the 0.25 -degree grids differ only in spatial resolution. The files with an " $x$ " suffix are associated with the aggregated data. For example, BIOMASS and BIOMASSX have exactly the same attributes, as is true for CLIMATE and CLIMATEX, DEMOG and DEMOGX, LAND and LANDX, and VEGT and VEGTX. Table 4 defines the attributes of each grid. 
Table 4. Item descriptions for the ten ARC/INFO export grids

\begin{tabular}{|c|c|c|c|c|c|c|c|}
\hline $\begin{array}{l}3.75-\mathrm{km} \text { grid } \\
\text { name }\end{array}$ & $\begin{array}{l}0.25 \text {-degree } \\
\text { grid name } \\
\end{array}$ & Column & $\begin{array}{l}\text { Item } \\
\text { name }\end{array}$ & $\begin{array}{l}\text { Input } \\
\text { width }\end{array}$ & $\begin{array}{r}\text { Output } \\
\text { width }\end{array}$ & Item type & $\begin{array}{l}\text { Variable } \\
\text { description }\end{array}$ \\
\hline \multirow[t]{4}{*}{$\begin{array}{l}\text { BIOMASS } \\
(2,200 \text { records } \\
\text { in .vat file) }\end{array}$} & $\begin{array}{l}\text { BIOMASSX } \\
(2,209 \text { records } \\
\text { in .vat file })\end{array}$ & 1 & Value & 4 & 10 & Binary & $\begin{array}{l}\text { Unique value for } \\
\text { each grid cell }\end{array}$ \\
\hline & & 5 & Count & 4 & 10 & Binary & $\begin{array}{l}\text { Cell count } \\
\text { associated with } \\
\text { each unique value }\end{array}$ \\
\hline & & 9 & $\mathrm{ac}$ & 4 & 16 & Binary & $\begin{array}{l}\text { Actual biomass } \\
\text { carbon }(\mathrm{Mg} \mathrm{C} / \mathrm{ha})\end{array}$ \\
\hline & & 13 & $\mathrm{pc}$ & 4 & 16 & Binary & $\begin{array}{l}\text { Potential biomass } \\
\text { carbon (Mg C/ha) }\end{array}$ \\
\hline \multirow[t]{6}{*}{$\begin{array}{l}\text { CLIMATE } \\
\text { (201 records } \\
\text { in .vat file) }\end{array}$} & $\begin{array}{l}\text { CLIMATEX } \\
\text { (154 records } \\
\text { in .vat file) }\end{array}$ & 1 & Value & 4 & 10 & Binary & $\begin{array}{l}\text { Unique value for } \\
\text { each grid cell }\end{array}$ \\
\hline & & 5 & Count & 4 & 10 & Binary & $\begin{array}{l}\text { Cell count } \\
\text { associated with } \\
\text { each unique value }\end{array}$ \\
\hline & & 9 & Climi & 4 & 16 & Binary & $\begin{array}{l}\text { Weck's Climatic } \\
\text { Index (code) }\end{array}$ \\
\hline & & 13 & precip & 4 & 16 & Binary & $\begin{array}{l}\text { Mean annual } \\
\text { precipitation } \\
\text { (code) }\end{array}$ \\
\hline & & 17 & climi-c & 12 & 12 & Character & $\begin{array}{l}\text { Weck's Climatic } \\
\text { Index (code } \\
\text { definition) }\end{array}$ \\
\hline & & 29 & precip-c & 12 & 12 & Character & $\begin{array}{l}\text { Mean annual } \\
\text { precipitation (code } \\
\text { definition) }\end{array}$ \\
\hline \multirow[t]{6}{*}{$\begin{array}{l}\text { DEMOG (166 } \\
\text { records in .vat } \\
\text { file) }\end{array}$} & $\begin{array}{l}\text { DEMOGX } \\
\text { (147 records } \\
\text { in .vat file) }\end{array}$ & 1 & Value & 4 & 10 & Binary & $\begin{array}{l}\text { Unique value for } \\
\text { each grid cell }\end{array}$ \\
\hline & & 5 & $\mathrm{C}$ & 4 & 10 & Binary & $\begin{array}{l}\text { Cell count } \\
\text { associated with } \\
\text { each unique value }\end{array}$ \\
\hline & & 9 & pop & 4 & 16 & Binary & $\begin{array}{l}\text { Population density } \\
\text { (code) }\end{array}$ \\
\hline & & 13 & pop-c & 18 & 18 & Character & $\begin{array}{l}\text { Population density } \\
\text { (code definition) }\end{array}$ \\
\hline & & 31 & cntry & 4 & 16 & Binary & Country (code) \\
\hline & & 35 & cntry-c & 24 & 24 & Character & $\begin{array}{l}\text { Country (code } \\
\text { definition) }\end{array}$ \\
\hline
\end{tabular}


Table 4 (continued)

\begin{tabular}{|c|c|c|c|c|c|c|c|}
\hline $\begin{array}{l}3.75-\mathrm{km} \text { grid } \\
\text { name }\end{array}$ & $\begin{array}{l}0.25 \text {-degree } \\
\text { grid name }\end{array}$ & Column & $\begin{array}{l}\text { Item } \\
\text { name }\end{array}$ & $\begin{array}{l}\text { Inpul } \\
\text { width } \\
\end{array}$ & $\begin{array}{r}\text { Output } \\
\text { width } \\
\end{array}$ & Item type & $\begin{array}{l}\text { Variable } \\
\text { description }\end{array}$ \\
\hline \multirow[t]{8}{*}{$\begin{array}{l}\text { LAND ( } 333 \\
\text { records in .vat } \\
\text { file) }\end{array}$} & $\begin{array}{l}\text { LANDX } \\
\text { ( } 244 \text { records } \\
\text { in .vat file) }\end{array}$ & 1 & Value & 4 & 10 & Binary & $\begin{array}{l}\text { Unique value for } \\
\text { each grid cell }\end{array}$ \\
\hline & & 5 & $\mathrm{C}$ & 4 & 10 & Binary & $\begin{array}{l}\text { Cell count } \\
\text { associated with } \\
\text { each unique value }\end{array}$ \\
\hline & & 9 & Slope & 4 & 16 & Binary & Slope (code) \\
\hline & & 13 & Elev & 4 & 16 & Binary & $\begin{array}{l}\text { Mean elevation } \\
\text { (code) }\end{array}$ \\
\hline & & 17 & Soilt & 4 & 16 & Binary & Soil texture (code) \\
\hline & & 21 & slope-c & 18 & 18 & Character & $\begin{array}{l}\text { Slope (code } \\
\text { definition) }\end{array}$ \\
\hline & & 39 & elev-c & 18 & 18 & Character & $\begin{array}{l}\text { Mean elevation } \\
\text { (code definition in } \\
\text { meters) }\end{array}$ \\
\hline & & 57 & soilt-c & 18 & 18 & Character & $\begin{array}{l}\text { Soil texture (code } \\
\text { definition) }\end{array}$ \\
\hline \multirow[t]{8}{*}{$\begin{array}{l}\text { VEGT ( } 258 \\
\text { records in .vat } \\
\text { file) }\end{array}$} & $\begin{array}{l}\text { VEGTX } \\
\text { (156 records } \\
\text { in .vat file) }\end{array}$ & 1 & Value & 4 & 10 & Binary & $\begin{array}{l}\text { Unique value for } \\
\text { each grid cell }\end{array}$ \\
\hline & & 5 & Count & 4 & 10 & Binary & $\begin{array}{l}\text { Cell count } \\
\text { associated with } \\
\text { each unique value }\end{array}$ \\
\hline & & 9 & Forest & 4 & 16 & Binary & Forest (code) \\
\hline & & 13 & Forest-c & 12 & 12 & Character & $\begin{array}{l}\text { Forest (code } \\
\text { definition) }\end{array}$ \\
\hline & & 25 & efz & 4 & 16 & Binary & $\begin{array}{l}\text { Ecofloristic zone } \\
\text { (code) }\end{array}$ \\
\hline & & 29 & efz-c & 18 & 18 & Character & $\begin{array}{l}\text { Ecofloristic zone } \\
\text { (code definition) }\end{array}$ \\
\hline & & 47 & veg & 4 & 16 & Binary & $\begin{array}{l}\text { Vegetation type } \\
\text { (code) }\end{array}$ \\
\hline & & 51 & veg-c & 24 & 24 & Character & $\begin{array}{l}\text { Vegetation type } \\
\text { (code definition) }\end{array}$ \\
\hline
\end{tabular}


The ARC/INFO IMPORT command or the ARCVIEW IMPORT program must be used to read the ten ARC/INFO export grids. The syntax for the ARC/INFO IMPORT command is "IMPORT <option><interchange_file><output>" (for example, "IMPORT GRID BIOMASS.E00 BIOMASS"). The syntax for the ARCVIEW IMPORT program is "IMPORT <interchange_file> <output>" (for example, "IMPORT BIOMASS.EOO BIOMASS"). The first and last ten lines of each ARC/INFO exported grid file in this database are as follows:

\section{Biomass.e00}

First 10 lines:

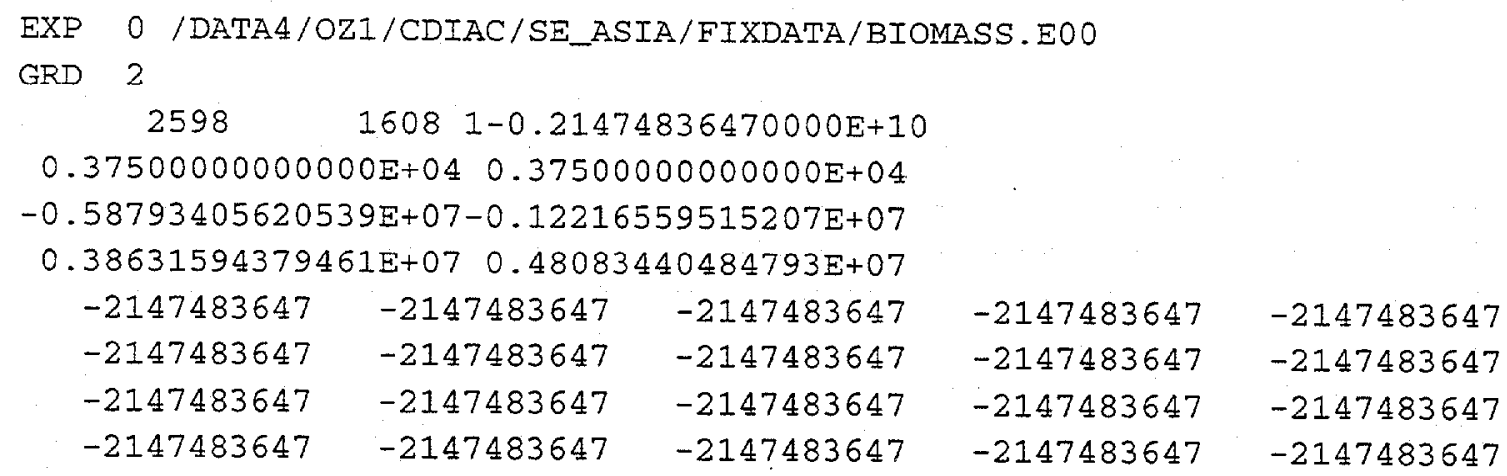

Last 10 lines:

$\begin{array}{rrrr}2193 & 2 & 46 & 221 \\ 2194 & 1 & 47 & 191 \\ 2195 & 1 & 48 & 206 \\ 2196 & 2 & 54 & 191 \\ 2197 & 3 & 47 & 221 \\ 2198 & 1 & 55 & 191 \\ 2199 & 2 & 55 & 206 \\ 2200 & 2 & 54 & -9999\end{array}$

EOI

EOS 


\section{Bomassx.e00}

First 10 lines:

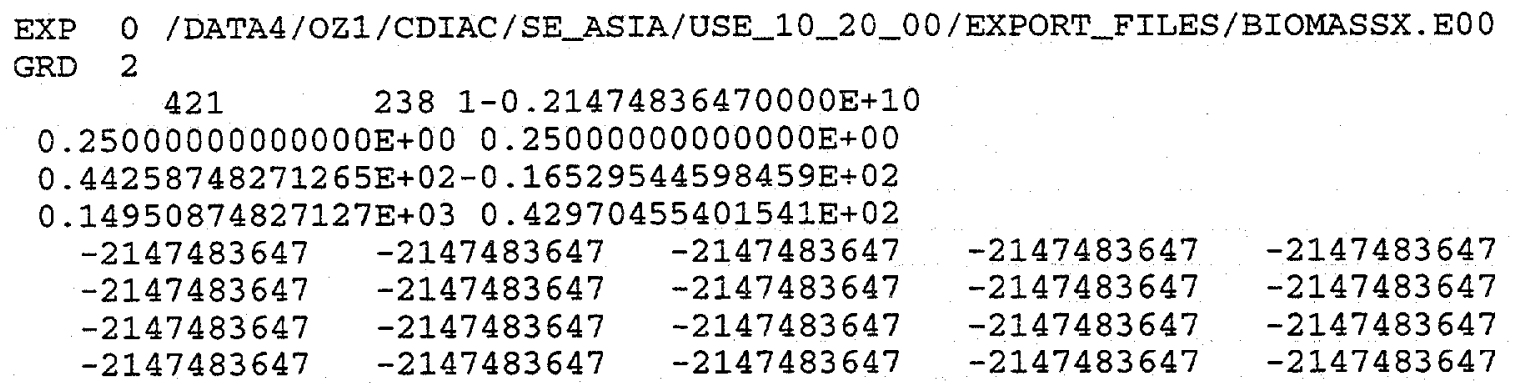

Last 10 lines:

$\begin{array}{rrrr}2202 & 1 & 180 & 352 \\ 2203 & 1 & 124 & 182 \\ 2204 & 1 & 86 & 219 \\ 2205 & 1 & 84 & 248 \\ 2206 & 1 & -9999 & 219 \\ 2207 & 1 & 102 & 189 \\ 2208 & 1 & 123 & 252 \\ 2209 & 1 & -9999 & 233\end{array}$

EOI

EOS 


\section{Climate.e00}

First 10 lines:

\begin{tabular}{|c|c|c|c|c|}
\hline EXP 0 /DATA 4 & CDIAC/SE & $/ F I X D A T A / N$ & $0 /$ CIIMATH & \\
\hline GRD & & & & \\
\hline 2598 & $1608 \quad 1-0.214$ & $836470000 E+10$ & & \\
\hline 0.375000000000 & $0 E+04 \quad 0.3750$ & $00000000 E+04$ & & \\
\hline-0.587934056205 & $9 E+07-0.1221$ & $59515207 E+07$ & & \\
\hline 0.386315943794 & $1 E+07 \quad 0.4808$ & $40484793 E+07$ & & \\
\hline-2147483647 & -2147483647 & -2147483647 & -2147483647 & -2147483647 \\
\hline-2147483647 & -2147483647 & -2147483647 & -2147483647 & -2147483647 \\
\hline-2147483647 & -2147483647 & -2147483647 & -2147483647 & -2147483647 \\
\hline-2147483647 & -2147483647 & -2147483647 & -2147483647 & -2147483647 \\
\hline
\end{tabular}

Last 10 lines:

$\begin{array}{rrrll}194 & 3 & 5 & 13101-125 & 5001-11000 \\ 195 & 6 & 7 & 13151-175 & 5001-11000 \\ 196 & 26 & 19 & 6901-1000 & 1001-1200 \\ 197 & 48 & 18 & 6801-900 & 1001-1200 \\ 198 & 12 & 20 & 41001-1700 & 601-800 \\ 199 & 6 & 20 & 31001-1700 & 401-600 \\ 200 & 4 & 20 & 61001-1700 & 1001-1200 \\ 201 & 20 & 13 & 5401-450 & 801-1000\end{array}$

EOI

EOS 


\section{Climatex.e00}

First 10 lines:

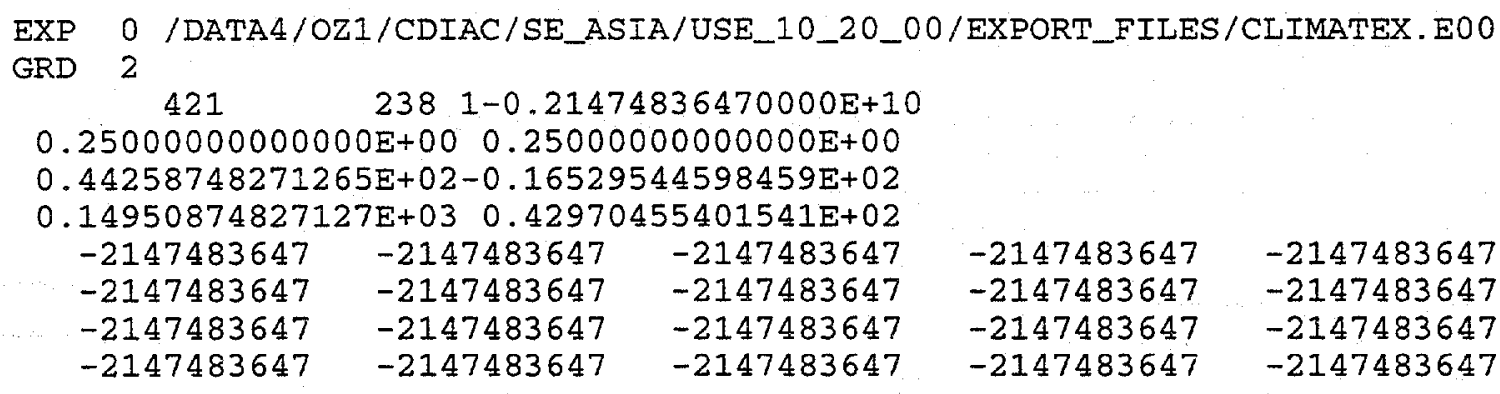

Last 10 lines:

$\begin{array}{rrrcl}147 & 4 & 20 & -9999 & 1001-1700 \\ 148 & 1 & 9 & 13201-250 & 5001-11000 \\ 149 & 1 & 18 & 6801-900 & 1001-1200 \\ 150 & 2 & 14 & 6451-500 & 1001-1200 \\ 151 & 1 & -9999 & 6 & 1001-1200 \\ 152 & 1 & 12 & 5351-400 & 801-1000 \\ 153 & 2 & 13 & 6401-450 & 1001-1200 \\ 154 & 1 & -9999 & 5 & 801-1000\end{array}$

EOI

EOS 


\section{Demog.e00}

First 10 lines:

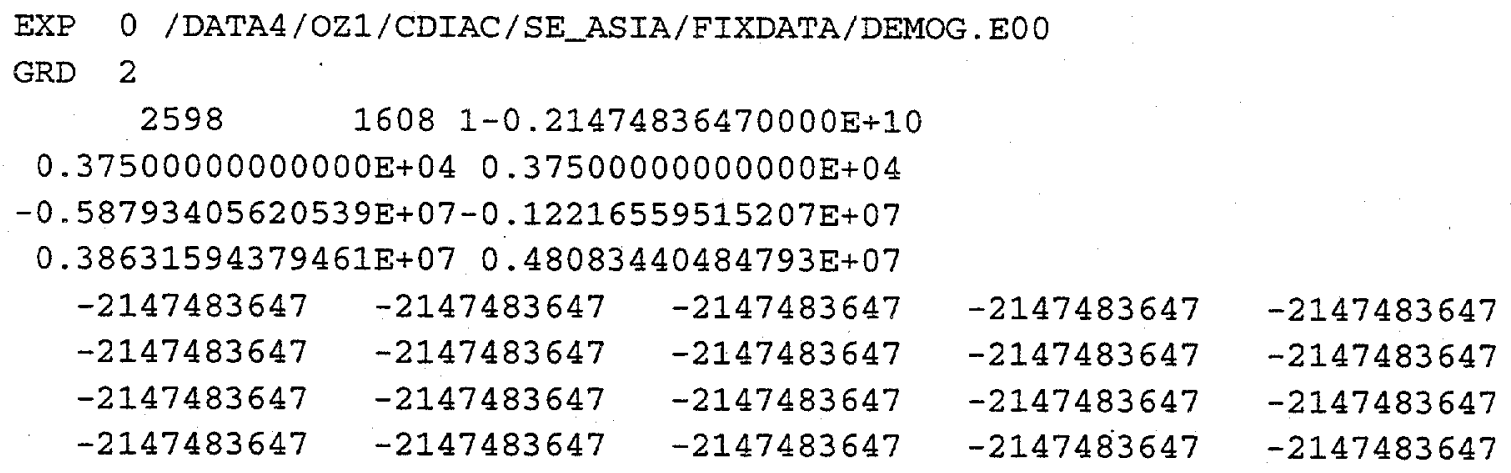

Last 10 lines:

$\begin{array}{rrrr}163 & 7777 & 10501-750 & \text { 13INDONESIA } \\ 164 & 124 & 8301-400 & \text { 13INDONESIA } \\ 165 & 2078 & 6151-200 & \text { 13INDONESIA } \\ 166 & 38 & 11751-1000 & \text { 13INDONESIA }\end{array}$

EOI

EOS 


\section{Demogx.e00}

First 10 lines:

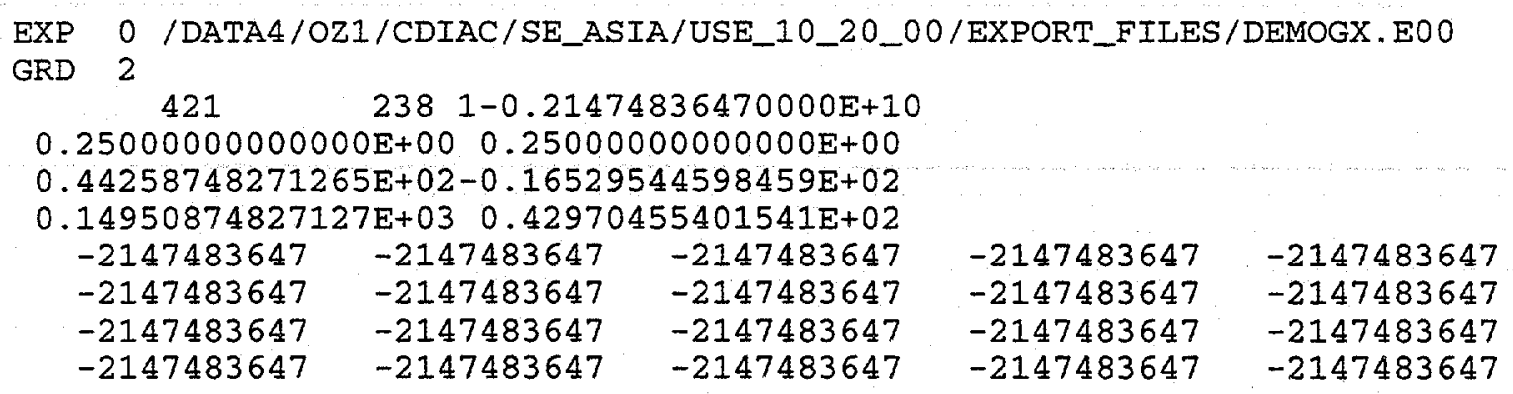

Last 10 lines:

$\begin{array}{rrrl}144 & 31 & 9401-500 & \text { 13INDONESIA } \\ 145 & 2 & 8301-400 & \text { 13INDONESIA } \\ 146 & 48 & 7201-300 & \text { 13INDONESIA } \\ 147 & 41 & 6151-200 & \text { 13INDONESIA }\end{array}$

EOI

EOS 


\section{Land.e00}

First 10 lines:

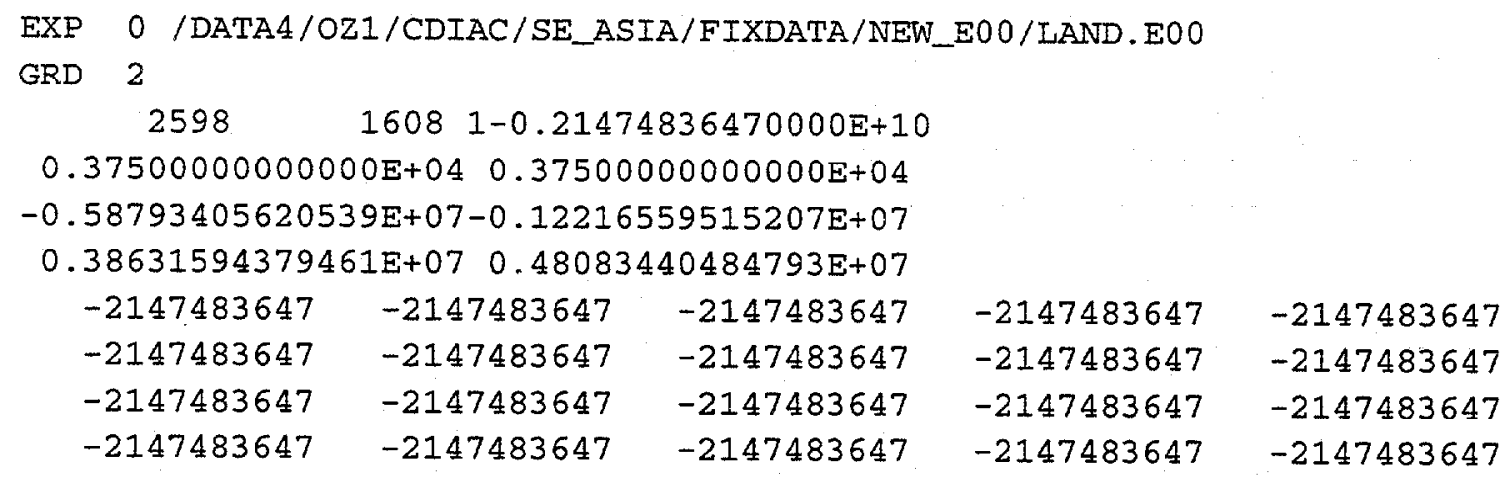

Last 10 lines:

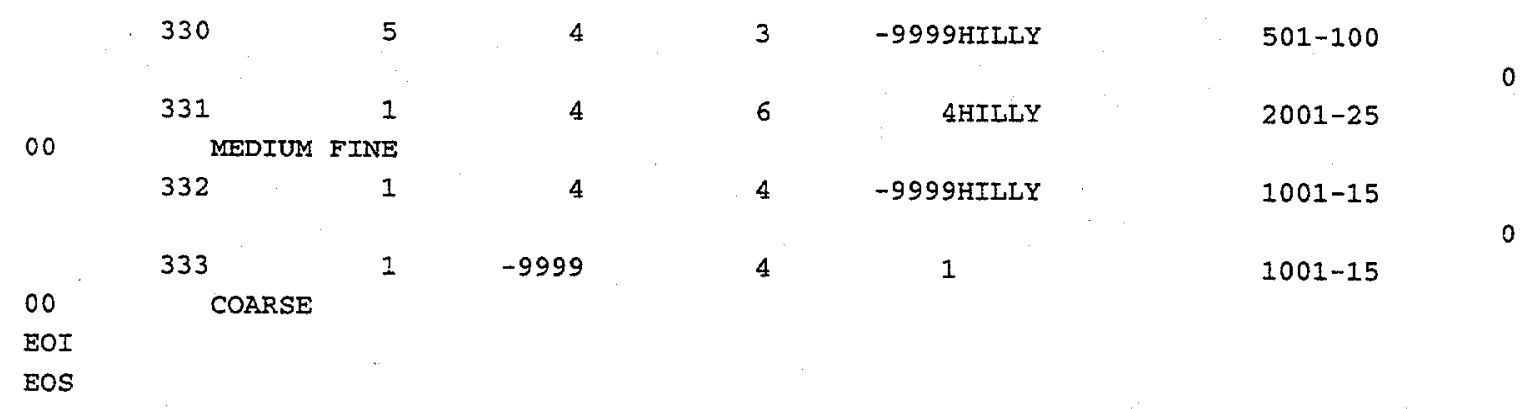




\section{Landx.e00}

First 10 lines:

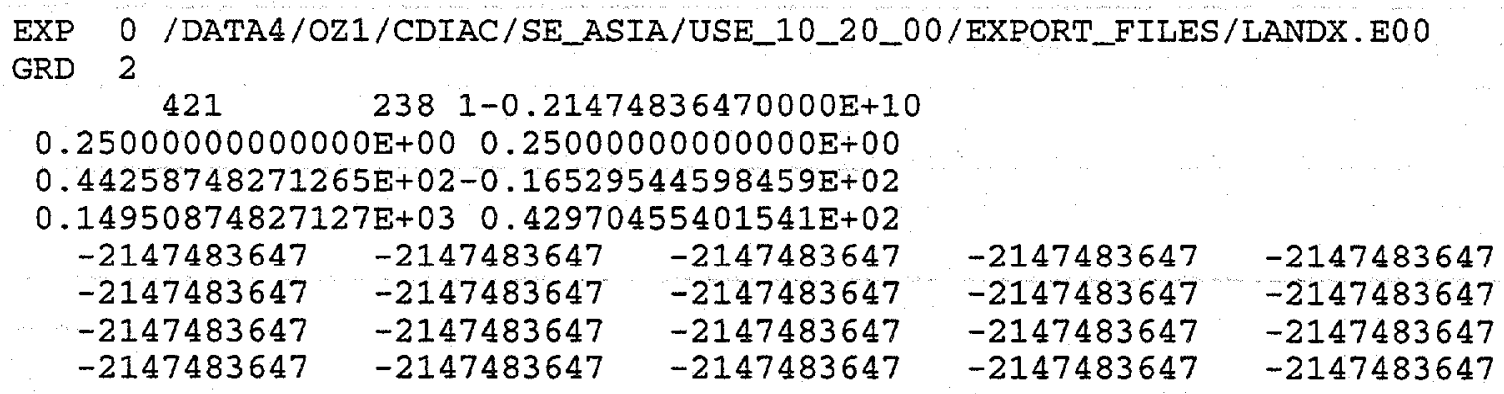

Last 10 lines:

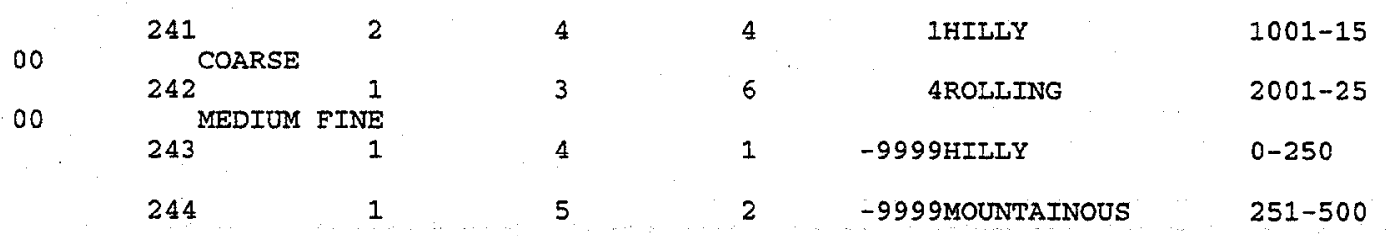

EOI

EOS 


\section{Vegt.e00}

First 10 lines:

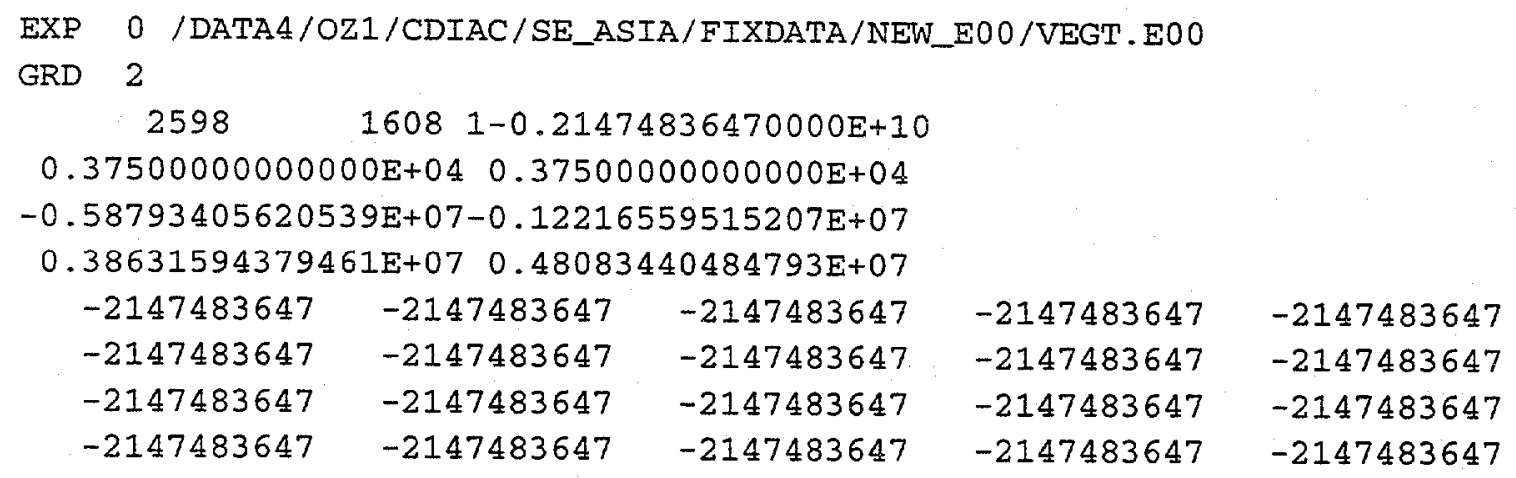

Last 10 lines:

$\begin{array}{lccc}\begin{array}{c}255 \\ \text { 18WATERBODIES }\end{array} & 2 & -9999 & \text { 3LOWLAND SEASONAL } \\ 256 & 2 & \text { 2NON-FOREST } & \text { 4LOWLAND DRY } \\ \begin{array}{l}\text { 18WATERBODIES } \\ 257\end{array} & 2 & \text { 1FOREST } & \text { 4LOWLAND DRY } \\ -9999 \quad 258 & 15 & -9999 & \text { 3LOWLAND SEASONAL } \\ & & & \\ \text { 13LOWLAND MONSOON FOREST } & & \\ \text { EOI } & \end{array}$




\section{Vegtx.e00}

First 10 lines:

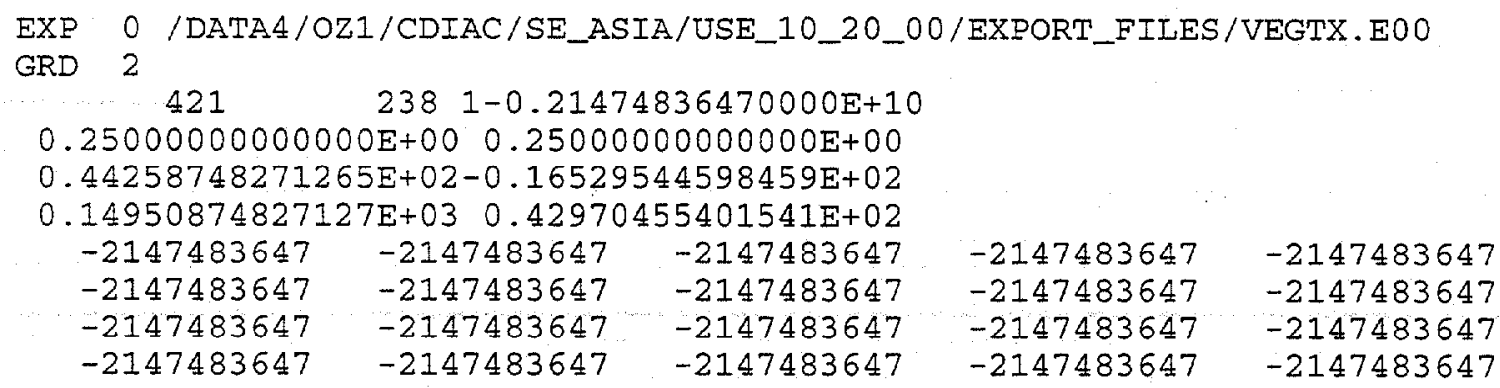

Last 10 lines:

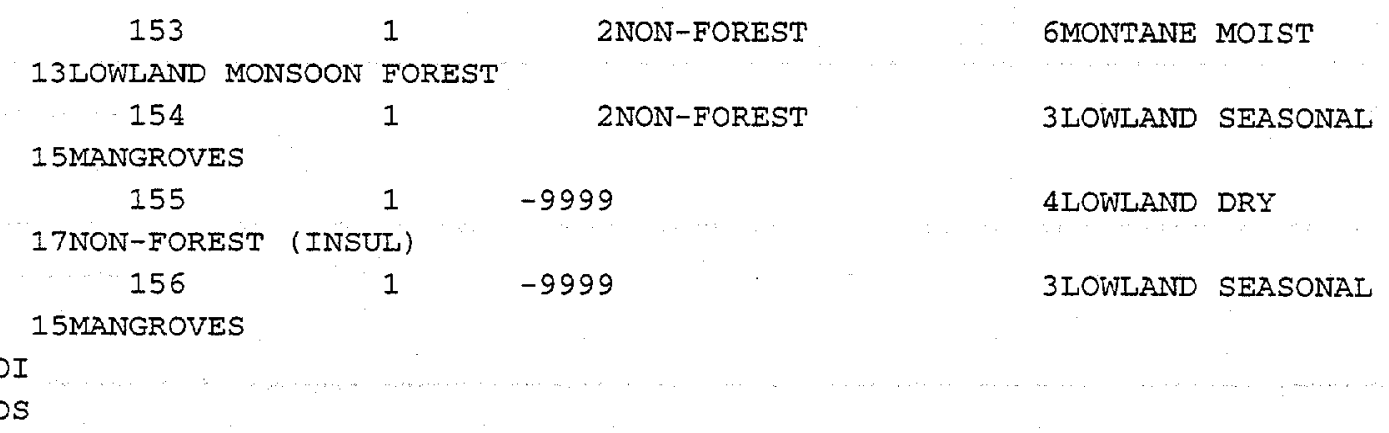

\section{DESCRIPTION, FORMAT, AND PARTIAL LISTINGS OF THE 24 ASCII DATA FILES PRODUCED BY THE ARC/INFO GRIDASCII COMMAND}

Twenty-four of the 26 ASCII data files included in this numeric data package were generated by the ARC/INFO GRIDASCII command. These files may be used with or without ARC/INFO software. The ASCIIGRID command must be used to read these files into ARC/INFO. The syntax for the ASCIIGRID command is "ASCIIGRID <in_ascii_file><out_grid> \{INT | FLOAT\}" (e.g., ASCIIGRID AC.DAT AC INT).

The first six lines of each file contain header information. The first line gives the number of columns, and the second gives the number of rows. The third and fourth lines define the lower left-hand $x$ (longitude) coordinate and the lower left-hand $y$ (latitude) coordinate. The fifth line defines the size of each grid cell, and the final line defines the missing-value indicator used in the 
file. For example, the files ac.dat, pc.dat, elev.dat, climi.dat, precip.dat, pop.dat, cntry.dat, slope.dat, soilt.dat, forest.dat, efz.dat, and veg.dat each contain the following as their first six lines (lines 1 to 6$)$ :

$\begin{array}{ll}\text { ncols } & 2598 \\ \text { nrows } & 1608 \\ \text { xllcorner } & -5879340.5620539 \\ \text { yllcorner } & -1221655.9515207 \\ \text { Cellsize } & 3750 \\ \text { NODATA_value } & -9999\end{array}$

The remaining 1608 lines of data contain 2598 values, one value for each grid cell. For example, the file forest.dat contains 2598 values that are 1, 2, or -9999 , identifying forest, non-forest, or unknown in each of the remaining 1608 lines in the file. Each file has a total of 1614 lines and a maximum line length of 15,587 characters.

These files may also be read using the following Fortran or SAS statements:

Fortran:

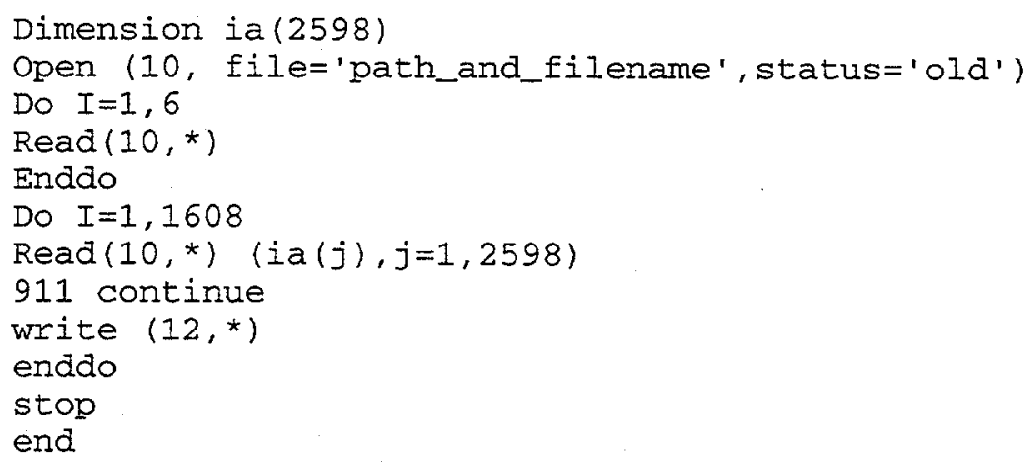

SAS:

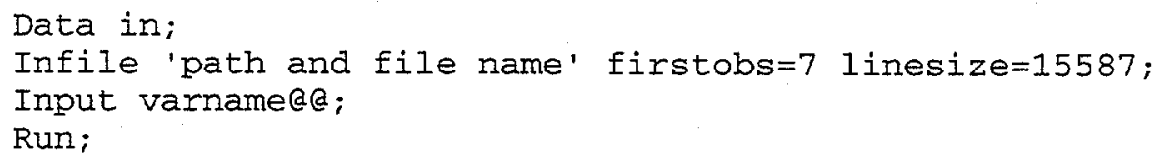

Each file should have $4,177,584$ records when this SAS input routine is used. 
Files acx.dat, pcx.dat, elevx.dat, climix.dat, precipx.dat, popx.dat, cntryx.dat, slopex.dat, soiltx.dat, forestx.dat, efzx.dat, and vegx.dat each contain the following as their first six lines (lines 1 to 6):

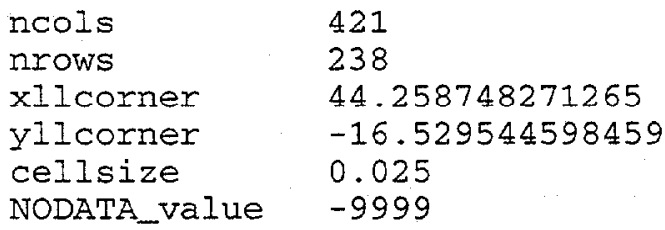

The remaining 238 lines of data in each file (lines 7 to 244) contain 421 values for the variable in the file. For example, the file forestx.dat contains 421 values that are either 1, 2, or -9999 , identifying forest, non-forest, or unknown in each of the remaining 238 lines in the file. Each file has a total of 244 lines and a maximum line length of 2525 characters.

These files may also be read by using the following Fortran or SAS statements:

Fortran:

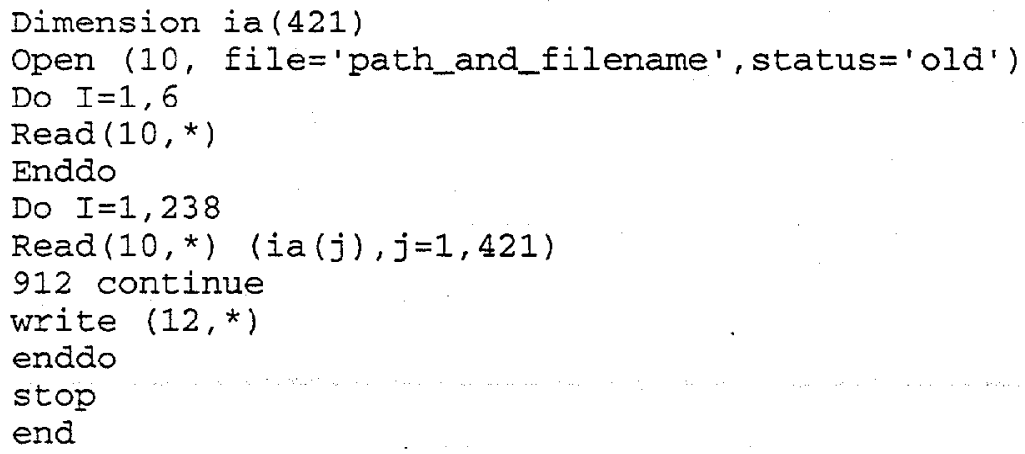

SAS:

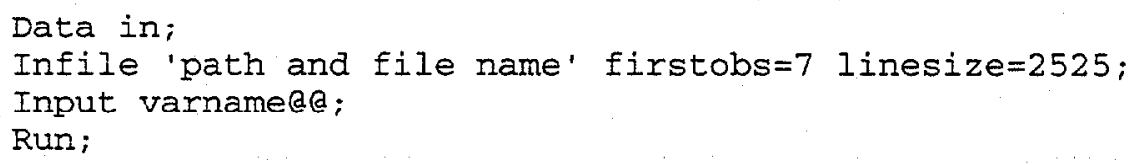

Each file should have 100,198 records when this SAS input routine is used. 
All the data values in climi.dat, climix.dat, precip.dat precipx.dat, pop.dat, popx.dat, cntry.dat, cntryx.dat, slope.dat, slopex.dat, elev.dat, elevx.dat, soilt.dat, soiltx.dat, forest.dat, forestx.dat, efz.dat, efzx.dat, veg.dat, and vegx.dat are integers. Each value has a corresponding character definition, according to the following specification:

\section{CNTRY CNTRY-C (country name)}

$\begin{array}{ll}1 & \text { Bangladesh } \\ 2 & \text { Burma } \\ 3 & \text { India } \\ 4 & \text { Cambodia } \\ 5 & \text { Laos } \\ 6 & \text { Malaysia (Peninsular) } \\ 7 & \text { Nepal } \\ 8 & \text { Pakistan* } \\ 9 & \text { Sri Lanka } \\ 10 & \text { Thailand } \\ 11 & \text { Vietnam } \\ 12 & \text { Malaysia (Insular) } \\ 13 & \text { Indonesiä } \\ 14 & \text { Philippines } \\ 15 & \text { Papua New Guinea* } \\ 16 & \text { Brunei }\end{array}$

* Although there are no data included in this database for Pakistan and Papua New Guinea, some border cells may be classified as such, as a result of the rasterization process (see Sect. 3, Data Limitations and Restrictions).

\section{EFZ-C (ecofloristic zone)}

$\begin{array}{ll}2 & \text { Lowland moist } \\ 3 & \text { Lowland seasonal } \\ 4 & \text { Lowland dry } \\ 6 & \text { Montane moist } \\ 7 & \text { Montane seasonal } \\ 9 & \text { Non-forest }\end{array}$




\begin{tabular}{|c|c|}
\hline VEG & VEG-C (vegetation type) \\
\hline 1 & Closed forest \\
\hline 2 & Secondary forest \\
\hline 3 & Shifting cultivation \\
\hline 4 & Open forest \\
\hline 5 & Forest mosaic \\
\hline 6 & Non-forest (Continental) \\
\hline 11 & Lowland rain forest \\
\hline 12 & Montane rain forest \\
\hline 13 & Lowland monsoon forest \\
\hline 14 & Montane monsoon forest \\
\hline 15 & Mangroves \\
\hline 16 & Inland swamp forest \\
\hline 17 & Non-forest (Insular) \\
\hline 18 & Waterbodies \\
\hline 19 & Degraded rain forest \\
\hline 20 & Degraded monsoon forest \\
\hline$\underline{\mathrm{POP}}$ & POP-C (population density in people $/ \mathrm{km}^{2}$ ) \\
\hline 1 & 1 to 25 \\
\hline 2 & 26 to 50 \\
\hline 3 & 51 to 75 \\
\hline 4 & 76 to 100 \\
\hline 5 & 101 to 150 \\
\hline 6 & 151 to 200 \\
\hline 7 & 201 to 300 \\
\hline 8 & 301 to 400 \\
\hline 9 & 401 to 500 \\
\hline 10 & 501 to 750 \\
\hline 11 & 751 to 1000 \\
\hline 12 & 1000 to 1500 \\
\hline 13 & 1500 to 2000 \\
\hline 14 & 2001 to 25000 \\
\hline
\end{tabular}




\section{PRECIP PRECIP-C (mean annual precipitation in $\mathrm{mm} / \mathrm{yr}$ )}

$\begin{array}{ll}1 & 1 \text { to } 200 \\ 2 & 201 \text { to } 400 \\ 3 & 401 \text { to } 600 \\ 4 & 601 \text { to } 800 \\ 5 & 801 \text { to } 1000 \\ 6 & 1001 \text { to } 1200 \\ 7 & 1201 \text { to } 1600 \\ 8 & 1601 \text { to } 2000 \\ 9 & 2001 \text { to } 2500 \\ 10 & 2501 \text { to } 3000 \\ 11 & 3001 \text { to } 4000 \\ 12 & 4001 \text { to } 5000 \\ 13 & 5001 \text { to } 11000\end{array}$

\section{ELEV ELEV-C (elevation in $\mathrm{m}$ )}

$\begin{array}{ll}1 & 0 \text { to } 250 \\ 2 & 251 \text { to } 500 \\ 3 & 501 \text { to } 1000 \\ 4 & 1001 \text { to } 1500 \\ 5 & 1501 \text { to } 2000 \\ 6 & 2001 \text { to } 2500 \\ 7 & 2501 \text { to } 3000 \\ 8 & 3001 \text { to } 4000 \\ 9 & 4001 \text { to } 5000 \\ 10 & 5001 \text { to } 10000\end{array}$

\section{SLOPE $\quad$ SLOPE-C (slope)}

$\begin{array}{ll}1 & \text { Level } \\ 2 & \text { Undulating } \\ 3 & \text { Rolling } \\ 4 & \text { Hilly } \\ 5 & \text { Mountainous } \\ 6 & \text { Unknown }\end{array}$




\begin{tabular}{ll} 
SOILT & SOILT-C (soil texture) \\
1 & Coarse \\
2 & Medium coarse \\
3 & Medium \\
4 & Medium fine \\
5 & Fine \\
6 & Unknown \\
& \\
FOREST & FOREST-C (forest or non-forest designation) \\
\hline & \\
1 & Forest \\
2 & Non-forest \\
& \\
CLIMI & CLIMI-C (Weck's Climatic Index) \\
\hline 1 & \\
2 & 1 to 25 \\
3 & 26 to 50 \\
4 & 51 to 75 \\
5 & 76 to 100 \\
6 & 101 to 125 \\
7 & 126 to 150 \\
8 & 151 to 175 \\
9 & 176 to 200 \\
10 & 201 to 250 \\
11 & 251 to 300 \\
12 & 301 to 350 \\
13 & 351 to 400 \\
14 & 401 to 450 \\
15 & 451 to 500 \\
16 & 501 to 600 \\
17 & 501 to 700 \\
18 & 701 to 800 \\
19 & 801 to 900 \\
20 & 901 to 1000 \\
& 1001 to 1700 \\
& \\
\hline &
\end{tabular}




\section{DESCRIPTION, FORMAT, AND PARTIAL LISTING OF THE COMPOSITE 3.75- KM AND 0.25-DEGREE ASCII DATA FILES}

The final two ASCII data files included in this numeric data package contain a composite of all the data in each of the 24 ASCII data files produced by the ARC/INFO GRIDASCII command. Each file contains the following variables: grid-cell identification number, longitude of the centerpoint of each grid cell, latitude of the centerpoint of each grid cell, estimated actual biomass carbon density in $\mathrm{Mg} / \mathrm{ha}$, estimated potential biomass carbon density in $\mathrm{Mg} / \mathrm{ha}$, country name, Weck's Climatic Index, ecofloristic zone, elevation, forest or non-forest designation, population density, mean annual precipitation, slope, soil texture, and vegetation type. The first file, se_asia.dat, contains data at $3.75-\mathrm{km}$ spatial resolution, whereas se_asiax.dat contains the same data at 0.25 -degree spatial resolution. While each file contains 15 variables, se_asia.dat has $4,177,584$ records, and se_asiax.dat has 100,198 records. Table 5 describes the format and content of the two files.

Table 5. Format and description of variables for the composite ASCII data files in this numeric data package (se_asia.dat and se_asiax.dat)

\begin{tabular}{llll}
\hline $\begin{array}{l}\text { Start } \\
\text { column }\end{array}$ & $\begin{array}{l}\text { End } \\
\text { column }\end{array}$ & $\begin{array}{l}\text { Variable } \\
\text { name }\end{array}$ & Variable description \\
\hline 1 & 7 & gid & $\begin{array}{l}\text { Unique grid-cell identification number. Values range from 1, for } \\
\text { the lower-left-most grid cell, to to 4,177,584 (in file se_asia.dat) or } \\
100,198 \text { (in file se_asiax.dat), for the upper-right-most grid cell } \\
\text { Longitude (decimal degrees) of the centerpoint of each 3.75-km (in } \\
\text { file se_asia.dat) or 0.25-degree (in file se_asiax.dat) grid cell } \\
\text { Latitude (decimal degrees) of the centerpoint of each 3.75-km (in }\end{array}$ \\
18 & 16 & long & file se_asia.dat) or 0.25-degree (in file se_asiax.dat) grid cell \\
27 & 31 & ac & Actual biomass carbon density in $\mathrm{Mg} / \mathrm{ha}$ \\
33 & 37 & pc & Potential biomass carbon density in $\mathrm{Mg} / \mathrm{ha}$ \\
39 & 43 & cntry & Country code \\
45 & 49 & climi & Weck's Climatic Index code \\
51 & 55 & efz & Ecofloristic zone code \\
57 & 61 & elev & Mean elevation code \\
63 & 67 & forest & Forest or non-forest code \\
69 & 73 & pop & Population density code \\
75 & 79 & precip & Mean annual precipitation code \\
81 & 85 & slope & Slope code \\
87 & 91 & soilt & Soil texture code \\
93 & 97 & veg & Vegetation code \\
\hline
\end{tabular}


The following listing provides the first and last ten lines of the two composite ASCII data files (se_asia.dat and se_asiax.dat).

\section{se_asia.dat}

\section{First 10 lines:}

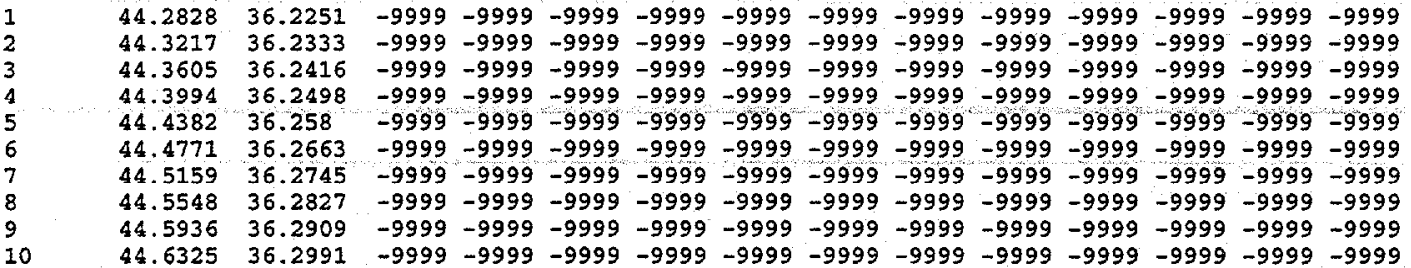

\section{Last 10 lines:}

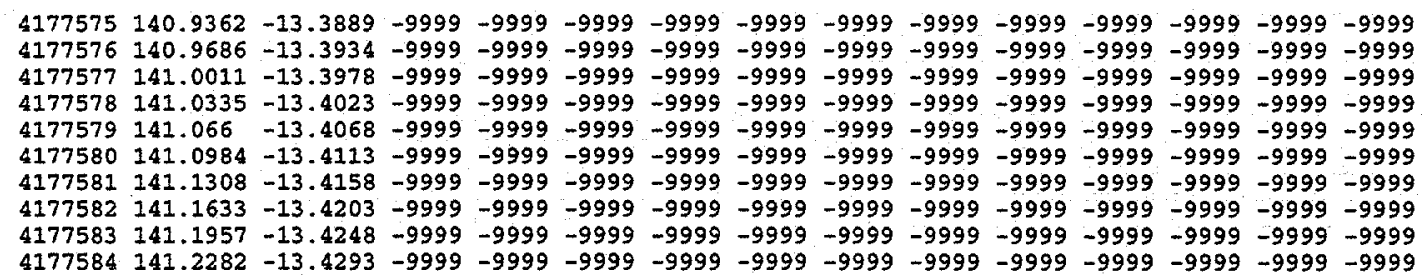

\section{se_asiax.dat}

\section{First 10 lines:}

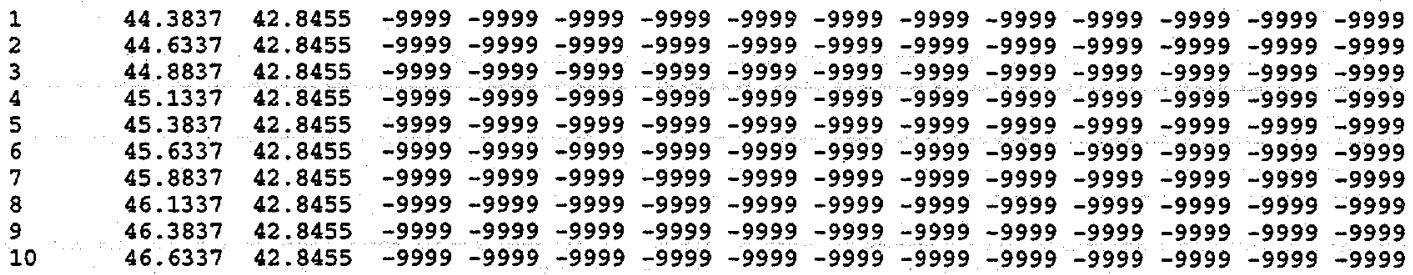

\section{Last 10 lines:}

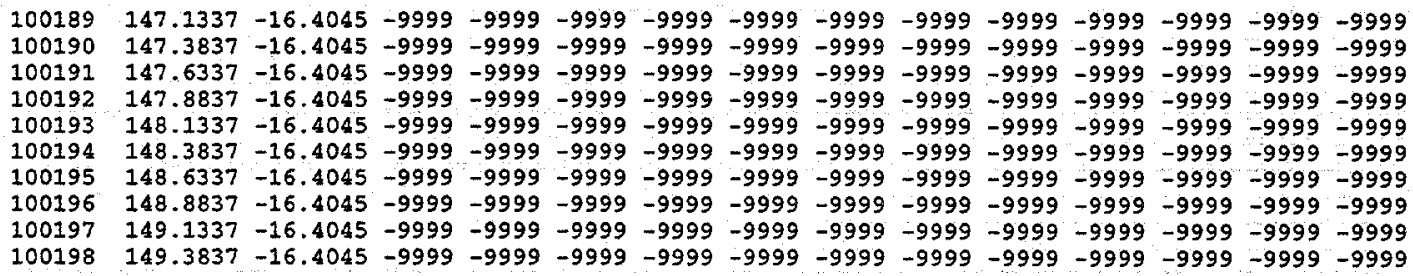


The following statements can be used to read ASCII data files into Fortran or SAS programs:

\section{For Fortran:}

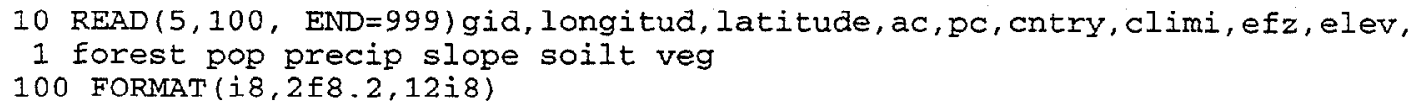

For SAS:

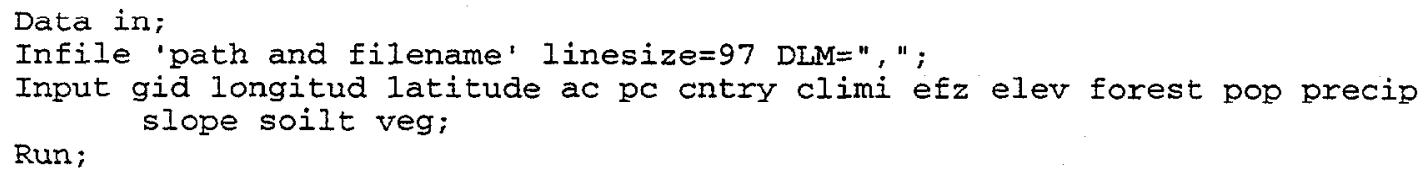

\section{STATISTICS OF THE FILES PROVIDED IN THIS NUMERIC DATA PACKAGE}

The statistics that follow in Table 6 are presented only as a tool to ensure the proper reading of the 36 data files in this numeric data package. The statistics given for the ten ARC/INFO export grid files are identical to the contents of the statistical attribute table (gridname.sta) for each imported ARC/TNFO grid. The 26 ASCII data files were generated after all occurrences of -9999 (missing-value indicator) were excluded. These statistics should not be interpreted as a summary of these data nor as an indicator of trends in these data.

\section{Table 6. Item statistics for the data files in this numeric data package}

\begin{tabular}{|c|c|c|c|c|c|c|c|c|c|c|}
\hline File name & Cell size & $\begin{array}{c}\text { Number } \\
\text { of } \\
\text { columns }\end{array}$ & $\begin{array}{r}\text { Number } \\
\text { of rows }\end{array}$ & $\begin{array}{r}\text { Number } \\
\text { of records }\end{array}$ & $\begin{array}{r}\text { Number } \\
\text { of unique } \\
\text { values }\end{array}$ & $\operatorname{Item}(s)$ & Minimum & Maximum & Mean & $\begin{array}{r}\text { Standard } \\
\text { deviation }\end{array}$ \\
\hline Biomass.e00 & $3.75 \mathrm{~km}$ & 2598 & 1608 & $\mathrm{n} / \mathrm{a}$ & 2200 & $\mathrm{ac}, \mathrm{pc}$ & 1 & 2200 & 270.32 & 503.09 \\
\hline Biomassx.e00 & $0.25 \mathrm{deg}$ & 421 & 238 & $n / a$ & 2209 & ac,pc & 1 & 2209 & 376.30 & 636.81 \\
\hline ac.dat & $3.75 \mathrm{~km}$ & 2598 & 1608 & 1614 & 281 & ac & 7 & 383 & 145.17 & 61.72 \\
\hline acx.dat & $0.25 \mathrm{deg}$ & 421 & 238 & 244 & 279 & ac & 7 & 336 & 143.33 & 61.28 \\
\hline pc.dat & $3.75 \mathrm{~km}$ & 2598 & 1608 & 1614 & 30 & $\mathrm{pc}$ & 14 & 393 & 255.16 & 68.71 \\
\hline pex.dat & $0.25 \mathrm{deg}$ & 421 & 238 & 244 & 288 & $\mathrm{pc}$ & 43 & 402 & 253.57 & 68.73 \\
\hline Climate.e00 & $3.75 \mathrm{~km}$ & 2598 & 1608 & $\mathrm{n} / \mathrm{a}$ & 201 & $\begin{array}{l}\text { climi, } \\
\text { precip }\end{array}$ & 1 & 201 & 67.92 & 38.40 \\
\hline Climatex.e00 & $0.25 \mathrm{deg}$ & 421 & 238 & $\mathrm{n} / \mathrm{a}$ & 154 & $\begin{array}{l}\text { climi, } \\
\text { precip }\end{array}$ & 1 & 154 & 57.46 & 35.34 \\
\hline climi.dat & $3.75 \mathrm{~km}$ & 2598 & 1608 & 1614 & 20 & climi & 1 & 20 & 11.67 & 6.06 \\
\hline climix.dat & $0.25 \mathrm{deg}$ & 421 & 238 & 244 & 20 & climi & 1 & 20 & 11.49 & 6.07 \\
\hline precip.dat & $3.75 \mathrm{~km}$ & 2598 & 1608 & 1614 & 13 & precip & 1 & 13 & 7.64 & 2.40 \\
\hline precipx.dat & $0.25 \mathrm{deg}$ & 421 & 238 & 244 & 13 & precip & 1 & 13 & 7.57 & 2.42 \\
\hline Demog.e00 & $3.75 \mathrm{~km}$ & 2598 & 1608 & $\mathbf{n} / \mathbf{a}$ & 166 & pop, cntry & 1 & 166 & 63.65 & 57.47 \\
\hline Demogx.e00 & $0.25 \mathrm{deg}$ & 421 & 238 & $\mathrm{n} / \mathrm{a}$ & 147 & pop, cntry & 1 & 147 & 54.65 & 52.70 \\
\hline pop.dat & $3.75 \mathrm{~km}$ & 2598 & 1608 & 1614 & 14 & pop & 1 & 14 & 4.20 & 2.86 \\
\hline popx,dat & $0.25 \mathrm{deg}$ & 421 & 238 & 244 & 14 & pop & 1 & 14 & 4.24 & 2.86 \\
\hline cntry.dat & $3.75 \mathrm{~km}$ & 2598 & 1608 & 1614 & 16 & entry & 1 & 16 & 6.94 & 4.67 \\
\hline
\end{tabular}


Table 6 (continued)

\begin{tabular}{|c|c|c|c|c|c|c|c|c|c|c|}
\hline File name & Cell size & $\begin{array}{c}\text { Number } \\
\text { of } \\
\text { columns }\end{array}$ & $\begin{array}{l}\text { Number } \\
\text { of rows }\end{array}$ & $\begin{array}{r}\text { Number } \\
\text { of records }\end{array}$ & $\begin{array}{r}\text { Number } \\
\text { of unique } \\
\text { values }\end{array}$ & Item(s) & Minimum & Maximum & Mean & $\begin{array}{l}\text { Standard } \\
\text { deviation }\end{array}$ \\
\hline cntryx.dat & $0.25 \mathrm{deg}$ & 421 & 238 & 244 & 15 & cntry & 1 & 16 & 6.83 & 4.64 \\
\hline Land.e00 & $3.75 \mathrm{~km}$ & 2598 & 1608 & $\mathrm{n} / \mathrm{a}$ & 333 & $\begin{array}{l}\text { slope, elev, } \\
\text { soilt }\end{array}$ & 1 & 333 & 159.97 & 56.40 \\
\hline Landx.e00 & $0.25 \mathrm{deg}$ & 421 & 238 & $\mathrm{n} / \mathrm{a}$ & 244 & $\begin{array}{l}\text { slope, elev, } \\
\text { soilt }\end{array}$ & 1 & 244 & 96.43. & 44.19 \\
\hline slope.dat & $3.75 \mathrm{~km}$ & 2598 & 1608 & 1614 & 6 & slope & 1 & 6 & 2.78 & 1.71 \\
\hline slopex.dat & $0.25 \mathrm{deg}$ & 421 & 238 & 244 & 6 & slope & 1 & 6 & 2.78 & 1.71 \\
\hline elev.dat & $3.75 \mathrm{~km}$ & 2598 & 1608 & 1614 & 10 & elev & 1 & 10 & 2.15 & 1.37 \\
\hline elevx.dat & $0.25 \mathrm{deg}$ & 421 & 238 & 244 & 10 & elev & 1 & 10 & 2.18 & 1.72 \\
\hline soilt.cat & $3.75 \mathrm{~km}$ & 2598 & 1608 & 1614 & 6 & soilt & 1 & 6 & 3.25 & 1.40 \\
\hline soiltx.dat & $0.25 \mathrm{deg}$ & 421 & 238 & 244 & 6 & soilt & 1 & 6 & 3.23 & 1.40 \\
\hline Vegt.e00 & $3.75 \mathrm{~km}$ & 2598 & 1608 & $\mathrm{n} / \mathrm{a}$ & 258 & $\begin{array}{l}\text { forest, efz, } \\
\text { veg }\end{array}$ & 1 & 258 & 70.40 & 55.49 \\
\hline Vegtx.e00 & $0.25 \mathrm{deg}$ & 421 & 238 & $\mathrm{n} / \mathrm{a}$ & 156 & $\begin{array}{l}\text { forest, efz, } \\
\text { veg }\end{array}$ & 1 & 156 & 44.51 & 38.83 \\
\hline forest.dat & $3.75 \mathrm{~km}$ & 2598 & 1608 & 1614 & 2 & forest & 1 & 2 & 1.59 & 0.49 \\
\hline forestx.dat & $0.25 \mathrm{deg}$ & 421 & 238 & 244 & 2 & forest & 1 & 2 & 1.60 & 0.49 \\
\hline efz.dat & $3.75 \mathrm{~km}$ & 2598 & 1608 & 1614 & 6 & efz & 2 & 9 & 3.29 & 1.56 \\
\hline efzx.dat & $0.25 \mathrm{deg}$ & 421 & 238 & 244 & 6 & efz & 2 & 9 & 3.32 & 1.59 \\
\hline veg.dat & $3.75 \mathrm{~km}$ & 2598 & 1608 & 1614 & 16 & veg & 1 & 20 & 7.59 & 4.87 \\
\hline vegx.dat & $0.25 \mathrm{deg}$ & 421 & 238 & 244 & 16 & veg & 1 & 20 & 7.49 & 4.80 \\
\hline \multirow[t]{15}{*}{ se_asia.dat } & $3.75 \mathrm{~km}$ & 97 & 4177584 & 4177584 & 4177584 & gid & 1 & 4177584 & 2088792.50 & 1205964.77 \\
\hline & & & & & 4177584 & Iongitud & 44.28 & 149.42 & 97.71 & 27.39 \\
\hline & & & & & 4177584 & latitude & -16.51 & 42.99 & 14.25 & 15.35 \\
\hline & & & & & 281 & ac & 7 & 383 & 145.17 & 61.72 \\
\hline & $\therefore$ & & & & 30 & pc & 14 & 393 & 255.16 & 68.71 \\
\hline & & & & & 20 & climi & 1 & 20 & 11.67 & 6.06 \\
\hline & 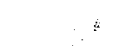 & & & & 13 & precip & 1 & 13 & 7.61 & 2.40 \\
\hline & & & & & 14 & pop & 1 & 14 & 4.20 & 2.86 \\
\hline & & & & & 16 & cntry & 1 & 16 & 6.94 & 4.67 \\
\hline & & & & & 6 & slope & 1 & 6 & 2.78 & 1.71 \\
\hline & & & & & 10 & elev & 1 & 10 & 2.15 & 1.67 \\
\hline & & & & & 6 & soilt & 1 & 6 & 3.25 & 1.40 \\
\hline & & & & & 2 & forest & 1 & 2 & 1.59 & 0.49 \\
\hline & & & & & 6 & efz & 2 & 9 & 3.29 & 1.56 \\
\hline & & & & & 16 & veg & 1 & 20 & 7.59 & 4.87 \\
\hline
\end{tabular}


Table 6 (continued)

\begin{tabular}{|c|c|c|c|c|c|c|c|c|c|c|}
\hline File name & Cell size & $\begin{array}{r}\text { Number } \\
\text { of } \\
\text { columns }\end{array}$ & $\begin{array}{r}\text { Number } \\
\text { of rows }\end{array}$ & $\begin{array}{r}\text { Number } \\
\text { of records }\end{array}$ & $\begin{array}{r}\text { Number } \\
\text { of unique } \\
\text { values }\end{array}$ & Item(s) & Minimum & Maximum & Mean & $\begin{array}{r}\text { Standard } \\
\text { deviation }\end{array}$ \\
\hline \multirow[t]{15}{*}{ se_asiax.dat } & $0.25 \mathrm{deg}$ & 97 & 100198 & 100198 & 100198 & gid & 1 & 100198 & 50099.50 & 28924.82 \\
\hline & & & & & 100198 & longitud & 44.38375 & 149.3837 & 96.88 & 30.38 \\
\hline & & & & & 100198 & latitude & -16.40454 & 42.84546 & 13.22 & 17.18 \\
\hline & & & & & 279 & $a c$ & 7 & 336 & . 143.33 & 61.28 \\
\hline & & & & & 288 & $\mathrm{pc}$ & 43 & 402 & 253.57 & 68.73 \\
\hline & & & & & 20 & climi & 1 & 20 & 11.49 & 6.07 \\
\hline & & & & & 13 & precip & 1 & 13 & 7.57 & 2.42 \\
\hline & & & & & 14 & pop & 1 & 14 & 4.24 & 2.86 \\
\hline & & & & & 16 & cntry & 1 & 16 & 6.83 & 4.64 \\
\hline & & & & & 6 & slope & 1 & 6 & 2.78 & 1.71 \\
\hline & & & & & 10 & elev & 1 & 10 & 2.18 & 1.72 \\
\hline & & & & & 6 & soilt & 1 & 6 & 3.23 & 1.40 \\
\hline & & & & & 2 & forest & 1 & 2 & 1.60 & 0.49 \\
\hline & & & & & 6 & efz & 2 & 9 & 3.32 & 1.59 \\
\hline & & & & & 16 & veg & 1 & 20 & 7.46 & 4.80 \\
\hline
\end{tabular}




\section{APPENDIX A: REPRINT OF PERTINENT LITERATURE}

Brown, S., L. R. Iverson, A. Prasad, and D. Liu. 1993. Geographical distributions of carbon in biomass and soils of tropical Asian forests. Geocarto International 4:45-59.

Copyright 1993 by Geocarto International Centre (G.P.O. Box 4122, Hong Kong;

http://www.geocarto.com) and reprinted in this report with kind permission from the publisher. 



\title{
Geographical Distributions of Carbon in Biomass and Soils of Tropical Asian Forests
}

\author{
Sandra Brown \\ Department of Forestry, University of Illinois \\ W-503 Turner Hall, 1102 S. Goodwin, Urbana, IL 61801, USA \\ Louis R. Iverson \\ US Forest Service \\ 359 Main Road, Delaware, OH 43015, USA \\ Anantha Prasad \& Dawning Liu \\ Illinois Natural History Survey \\ 607 E. Peabody, Champaign, IL 61820, USA
}

\begin{abstract}
Estimates of geographically referenced carbon densities and pools in forest soils and vegetation of tropical Asia were modeled using a geographic information system. Spatial data bases of climatic, edaphic, and geomorphologic indices, and vegetation were first used to estimate the potential carbon densities (without human impacts) in above- and below-ground biomass of forests in 1980. The resulting map was then modified to actual carbon density estimates as a function of population density and three climatic regimes. Soil organic carbon estimates were generated by calculating mean carbon densities, to $100 \mathrm{~cm}$ depth, from pedon data for tropical forests, stratified by soil texture classes and climatic regimes. The means for each class were assigned to a texture/climate map for all of tropical Asia. The average carbon density for the tropical forests of Asia was $255 \mathrm{Mg} \mathrm{ha}^{-1}$ in potential biomass, $144 \mathrm{Mg} \mathrm{ho}^{-1}$ in actual biomass and $148 \mathrm{Mg} \mathrm{ha}^{-1}$ in soils, which correspond to total carbon estimates of 74,42 , and 43 Pg, respectively. Three out of the 14 countries considered (Indonesia, India, and Myanmar) accounted for about $70 \%$ of the total carbon pools in tropical Asian forests. Carbon densities and pools in vegetation and soil varied widely by ecofloristic zone and country.
\end{abstract}

\section{Introduction}

Recent estimates of the carbon source from changes in tropical land use to the atmosphere vary widely, from 0.4 to $2.5 \mathrm{PgC} \mathrm{yr}-1\left(1 \mathrm{Pg}=10^{15} \mathrm{~g}\right)$ for 1980 (Detwiler and Hall 1988, Hall and Uhlig 1991, Houghton et al. 1987) and from 1.2 to $2.2 \mathrm{Pg} \mathrm{C} \mathrm{yr}^{-1}$ for 1990 (Houghton 1992). The uncertainty in these estimlates is caused by high uncertanities in rates of land-use change, rates of forest degradation, the amount of carbon in vegetation and soil of the forests being cleared, and the allocation of carbon after clearing and burning (Brown and Iverson 1992). Many of these uncertainties could be resolved if maps describing the spatial distribution of land-use change and carbon in vegetation and soils were available. These coincident maps would enable changes in land use to be matched with appropriate vegetation and soil carbon.

High resolution satellite imagery, collected at more than one time interval for the entire tropics, will eventually allow for mapping and more precise estimates of land-use change. This mapping has been done already for a few countries, e.g., the Amazon Basin in Brazil (Skole and Tucker 1993). However, current technology in remote sensing has been shown to be incapable of reliably determining the biomass of complex tropical forests (Nelson et al. 1988). Alternative methods are therefore needed for this aspect of the effort. Recent work (Brown and Iverson 1992, Iverson et al. 1994) has demonstrated the feasibility of generating spatial distributions of tropical forest aboveground biomass density using a modeling approach in a geographic information system (GIS). To our knowledge no other similar attempts have been made.

We considered using maps of vegetation or life zones (e.g., Prentice et al. 1992, Emanuel et al. 1985) and average biomass carbon densities (e.g., Ajtay et al. 1979, Brown and Lugo 1982, Fearnside 1992, Olson $e t$ al. 1983, Whittaker and Likens 1973) to produce spatial distributions of forest biomass carbon density. 
However, we rejected this approach because most of this work is concerned with potential vegetation and not actual, the data base for generating average biomass carbon densities is poor and generally does not represent the population of interest (i.e., all tropical forests of Asia), and the use of average values from a few forest types does not reflect the spatial heterogeneity of forest areas caused by differences in environmental factors and human impacts (cf. Brown and Lugo 1992, Brown and Iverson 1992 for further discussion).

A method is also needed to generate spatial distributions of soil carbon density because of the importance of soil to the global carbon cycle (Detwiler 1986). At present, estimates of carbon pools in soils for use in terrestrial carbon models are derived from highly aggregated life zone averages (Post et al. 1982) or on averages by pedons based on the Food and Agriculture Organization Soil Map of the World (FAO-UNESCO 1971-1981, Eswaran et al. 1993).

The goals of this paper are to present methods and results for producing spatial estimates of carbon densities (carbon per unit area, $\mathrm{Mg} \mathrm{ha}^{-1}\left[1 \mathrm{Mg}=10^{6} \mathrm{~g}\right]$ ) and total carbon pools (product of carbon density and area, $\mathrm{Pg}$ ) in vegetation and soils for tropical Asian forests. We build on the work of Iverson et al. (1994) for the carbon in forest vegetation and develop a new method for soil carbon densities. Area weighted average carbon densities and total carbon in vegetation and soils by ecological zones, country, and whole region are reported and compared. We conclude with a discussion of the implications of our results to the global carbon cycle.

\section{Methods}

\section{Study Area}

The area of study consists of the continental and insular portions of tropical Asia, including the following countries: Bangladesh, Brunei, Cambodia, India, Indonesia, Laos, Malaysia (Peninsular, Sabah and Sarawak), Myanmar, Nepal, Philippines, Sri Lanka, Thailand, and Vietnam. General descriptions of the forests of this region are given in Whitmore (1984) and Collins et al. (1991). The region is composed of very diverse forest formations ranging from very dry forests in parts of India to the moist evergreen forests of Malaysia and Indonesia. Most of this diversity of forest formations can be attributed to the very heterogeneous rainfall regimes, including total amount and seasonality (Whitmore 1984). Geomorphologic and edaphic patterns are responsible for further differentiation of the vegetation. Human use of the region adds another level of complexity to the forest landscape resulting in forests at different stages of degradation, including mature, logged, young to late secondary, and highly degraded.

The occurrence of frequent, large-scale natural disturbances are not widespread across the region. Tropical cyclones occur frequently in Bangladesh, parts of India and Myanmar, and the Philippines. To what degree the structure of forests over the long term are affected by these events is poorly known and are not explicitly included in the analysis.

\section{General Procedure for GIS Processing}

All data were processed with the ARC/INFO and Grid (raster) GIS, with the exception of the interpolation of climatic station data which was performed with GRASS (Construction Engineering Research Laboratory, Champaign, IL, USA). Processing involving areal calculations was performed separately on the continental and insular regions, projected into the Albers equal area projection, to reduce the distortion in pixel size near the east and west edges of the data sets. The pixel size was $3.75 \mathrm{~km} \times 3.75 \mathrm{~km}$. The data were converted into a geographic projection (i.e., latitude and longitude) for display purposes.

As with any overlay process involving highly generalized global data sets, there will be many sources of error and one cannot precisely locate or map the carbon density in any particular pixel. However, the general patterns across the regions or countries should be more reliable.

\section{Carbon Density of Forest Vegetation}

We estimate the carbon density of above-ground and below-ground biomass in trees with a diameter of $\geq 10 \mathrm{~cm}$. In more open forests where trees are often smaller in diameter, the minimum diameter was lowered to $5 \mathrm{~cm}$. We did not include the biomass of other living components such as saplings, shrubs, vines, and other understory plants because they represent a small fraction in closed forests $(<5 \%$ of the aboveground biomass; Brown and Lugo 1992). These other components, however, could represent a larger proportion of the total biomass in open forests, but data are presently lacking to support this possibility. We did not include estimates for fine or coarse (woody debris) litter because the data base available is unsuitable for extrapolating to all the Asian tropics and we do not know to what extent this material is used by people for fuel, fodder, or other uses. A more detailed discussion of the significance of omitting these other vegetation components is given in Brown and Lugo (1992).

\section{Above-ground Biomass Carbon Density}

For producing a spatial distribution of forest biomass carbon density, we used the approach described in 
Iverson et al. (1994). We extended the analysis detailed in Iverson et al. to include countries in insular Asia as well as in continental Asia, included an estimate for below-ground biomass density as well as aboveground, and converted the results from biomass units to carbon units ( 1 unit biomass $=0.5$ units of carbon). Because of the paucity of data on forest biomass in the region (Brown and Iverson 1992), a modeling approach in a GIS was used. We assumed that the present distribution of forest biomass density is a function of the potential amount that the landscape can support under the prevailing climatic, edaphic and geomorphologic conditions and the cumulative impact of human activities such as logging, fuelwood collection, shifting cultivation, and other activities that reduce the biomass.

The approach was to first develop a spatial distribution of potential (i.e., without the influence of humans) above-ground biomass density. This was accomplished using the following data layers, full descriptions of which are given in Iverson et al. (1994): (1) elevation was mapped by re-scaling, in $15 \mathrm{~m}$ intervals from sea level to about $4000 \mathrm{~m}$, the US National Geophysical Data Center's elevation map, (2) five soil texture classes were mapped by reclassifying the FAOUNESCO Soil Map of the World, (3) five slope classes were mapped based on the FAO-UNESCO Soil Map of the World, (4) annual precipitation was mapped by interpolation of meterological station data (about 600 stations) obtained from the agro-meterological database of FAO, and (5) integrated climate index was mapped by interpolation of a modified Weck's index (Weck 1970 ) using the same meterological station data as for precipitation.

The general methodology for processing these data layers follows that of Risser and Iverson (1988). A simple additive model of the data layers is used to arrive at a score for each pixel across the region. The scores are then calibrated with actual estimates of biomass density for mature forests.

The specific model that we used for mapping an index of potential biomass density combined the above data layers, weighted according to their effect on biomass density. The data layers of precipitation, climatic index, and soil texture were each assigned a maximum value of 25 points; elevation and slope classes together were assigned another 25 points. The maximum score for any pixel was thus 100 points. The initial weighting scheme for each layer was arrived at from information in Brown and Lugo (1982), Holdridge (1967), and Whitmore (1984). Model results were compared to known localities in the region, forest inventories, other literature sources, personal experience, and colleagues expert in the region (e.g., E. Flint and J. Richards, Duke University; cf. Flint and
Richards 1994, Richards and Flint 1994). This process was repeated with the weight of climatic and edaphic factors adjusted within certain bounds to yield the most satisfactory map (Iverson et al. 1994).

Here we describe the weighting scheme for precipitation to serve as an example of our approach. Precipitation, ranging from less than 400 to more than $5000 \mathrm{~mm} \mathrm{yr}^{-1}$, was scaled to 12 classes, taking $400 \mathrm{~mm}$ $\mathrm{yr}^{-1}$ as the lower limit at which forests grow (Holdridge 1967). From 400 to $1200 \mathrm{~mm} \mathrm{yr}^{-1}$, each class interval was $200 \mathrm{~mm} \mathrm{yr}^{-1}$; from 1201 to $3600 \mathrm{~mm} \mathrm{yr}^{-1}$, each class interval was $400 \mathrm{~mm} \mathrm{yr}^{-1}$; and the last two classes were 3601 to $5000 \mathrm{~mm} \mathrm{yr}^{-1}$ and $>5000 \mathrm{~mm} \mathrm{yr}^{-1}$ (based on Brown and Lugo 1982, Holdridge 1967). The weighting factor for biomass density in the model was assumed to: (1) increase linearly from 3 points for the first precipitation class to the maximum of 25 points for the 9 th class (2801-3200 $\mathrm{mm} \mathrm{yr}^{-1}$ ), and (2) decrease linearly to a minimum of 17 points for the 12 th class (Brown and Lugo 1982). The details of assumptions and basis for the weighting schemes derived for the other layers are described in Iverson et al. (1994).

Overlaying all the data layers according to their weighting schemes resulted in a map of indices which was then calibrated to biomass density units using data from the literature for mature forest of the region. This posed a challenge because few measurements of mature forest biomass have been made in this region (Brown et al. 1991). Sufficient data were available to set the upper and lower limits of the potential biomass index (details of sources are given in Iverson et al. 1994). Once these were established, we assumed that biomass density was linear between these limits, using additional literature sources to establish intermediate biomass density classes. The two upper-limit classes for potential biomass density were $550-600 \mathrm{Mg} \mathrm{ha}^{-1}$ and $>600 \mathrm{Mg} \mathrm{ha}^{-1}$; the lower limit was $<50 \mathrm{Mg} \mathrm{ha}^{-1}$; and the ten classes in between were $50 \mathrm{Mg} \mathrm{ha}^{-1}$ wide (Iverson et al. 1994).

The distribution of potential above-ground biomass density was then "cut" with a map of forested areas as of about 1980 to produce maps of potential biomass density for forests lands only. The forest/non-forest maps used for this step were derived from two sources: (1) a vegetation map of continental tropical Asia produced by the Food and Agriculture Organization for its 1990 Tropical Forest Resource Assessment Project (Food and Agriculture 1989, K.D. Singh, FAO, pers. comm. 1990) and (2) a digital map of the forest areas for insular Asian countries reported in Collins et al. (1991; obtained from the World Conservation Monitoring Center [WCMC], Cambridge, England). The FAO vegetation and WCMC forest maps were developed from many multi-date sources (late 1970s to early 1980s), thus the exact year that they represent 
is not accurately known. We assumed that they represent the state of the vegetation in 1980 (K.D. Singh, pers. comm.). The forest/non-forest map when combined with the potential biomass density map produced a distribution of potential biomass carbon density in those areas remaining as forests as of 1980 (referred to as PCD-80).

The final step was to add the cumulative impact of human acitvity on reducing forest biomass from its potential. For this step, we assumed that population density could be used as a surrogate index to account for this reduction in biomass and that the impact of humans on forests varies by climate (Iverson et al. 1994, Flint and Richards 1994, Richards and Flint 1994). That is, the same human population density causes relatively more forest degradation in drier than in humid climates because of the inherent ability of humid forests to produce biomass more rapidly (Brown and Lugo 1982).

Degradation ratios for forests were calculated as the ratio of biomass density estimated from data given in forest inventories (Brown et al. 1989, 1991) to potential biomass density from the model (Iverson et al. 1994). These ratios were based on recent (since the 1960s) inventories suitable for converting to biomass, and were conducted in various subnational units of Bangladesh, India, Malaysia (Peninsular and Sarawak), Philippines, Sri Lanka, Thailand, and Vietnam (see Brown et al. 1991), for a total of 47 units. It was assumed that these inventories were done in a representative sample of the forests in a given subnational unit and that the weighted biomass density was the best estimate of the forest biomass density for the whole unit at that time. A weighted estimate of the potential biomass density for the same subnational unit was obtained from the PCD-80 map.

The calculated degradation ratios and their corresponding population density, taken at the time nearest to the time of the inventory for each unit, were stratified by three climatic regimes (aseasonally moist $=>2000 \mathrm{~mm} \mathrm{yr}^{-1}$, seasonally moist $=1500-2000 \mathrm{~mm} \mathrm{yr}^{-1}$, and $\left.\mathrm{dry}=<1500 \mathrm{~mm} \mathrm{yr}^{-1}\right)$. These data were then subject to least squares simple linear regression analysis. The three resulting equations are shown in Figure 1. Default solutions to these equations at very high or low population densities were set at 0.06 (the lowest value obtained from inventories) and 1.0 (no degradation), respectively. These equations show that the rate of forest degradation, as indicated by the slopes of the equations, with increasing population is highest in the dry forests, followed by the seasonal and the moist as hypothesized above.

A population density map of the region was generated from population data reported by subnational units as obtained from the Demographic and Statistics Department of the Food and Agriculture Organization (see Iverson et al. 1994). The equations in Figure 1 were used with the maps of population density, rainfall, and $\mathrm{PCD}-80$ to produce a spatial distribution of the actual biomass carbon density (ACD) of forests.

\section{Below-ground Biomass Carbon Density}

From the few pantropical data available on belowground biomass (Brown and Lugo 1982, Fearnside
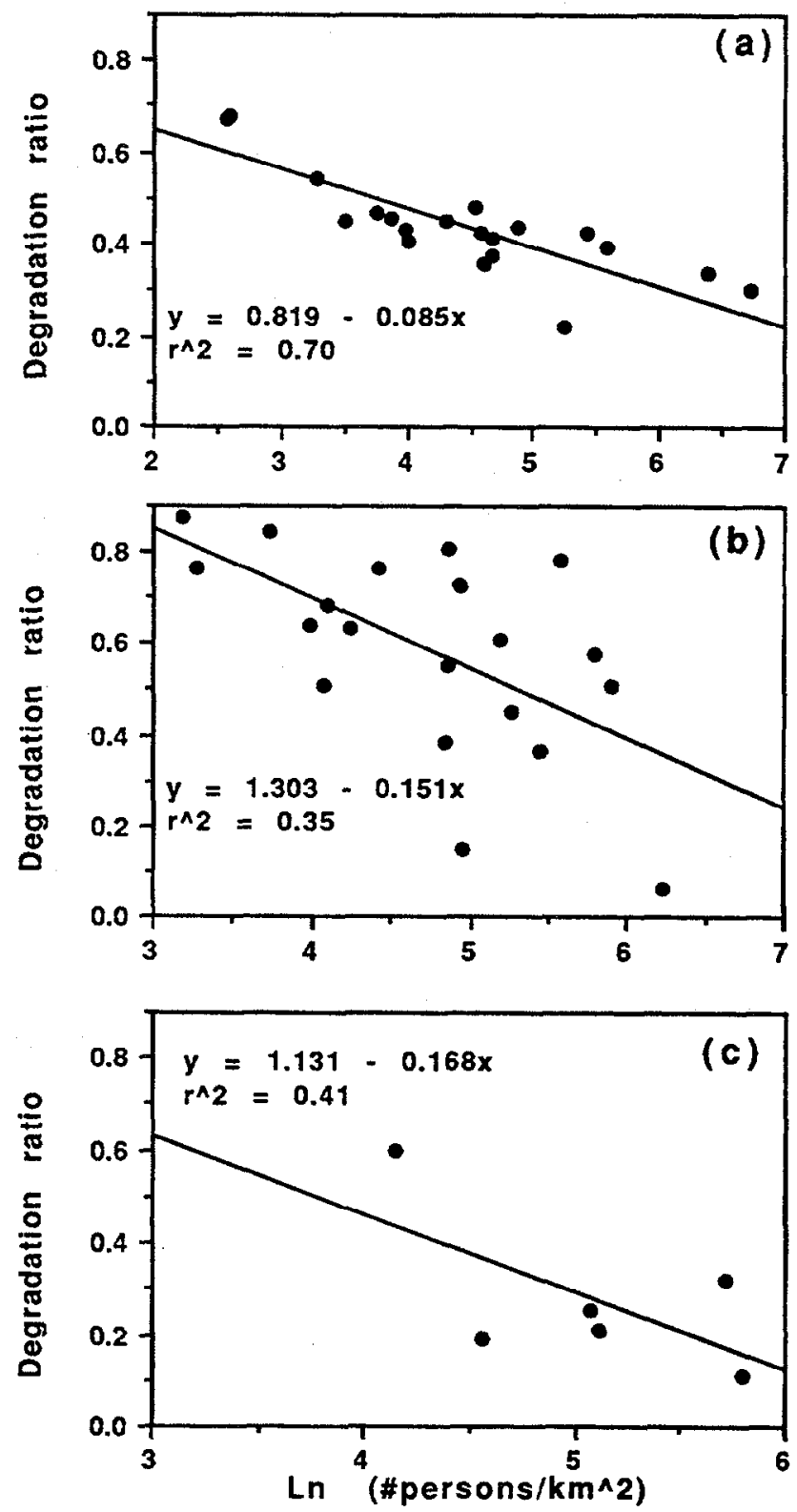

Figure 1 Relationship between biomass degradation ratios (actual to potential biomass density) and the natural logarithm (Ln) of population density for (a) moist, (b) seasonal, and (c) dry climatic zones (see text for description of these zones). The regression equation for (a) is for population densities $>12$ persons $\mathrm{km}^{-2}$; for population densities $(\mathrm{PD})$ less than this, the degradation ratio $=1$ $0.015^{*} \mathrm{PD}$. 
1992, Olson et al. 1983), we calculated root:shoot ratios. We then stratified these ratios according to three climatic zones: (1) lowland dry $=\leq 1200 \mathrm{~mm} \mathrm{yr}^{-1}$ and elevation $\leq 1000 \mathrm{~m}$ (no montane dry forests existed in 1980), (2) lowland and montane seasonal $=>1200$ $2000 \mathrm{~mm} \mathrm{yr}^{-1}$ for elevation below $1000 \mathrm{~m}$, and 500-1200 $\mathrm{mm} \mathrm{yr}^{-1}$ for elevation above $1000 \mathrm{~m}$, and (3) lowland and montane moist $=>2000 \mathrm{~mm} \mathrm{yr}^{-1}$ over all elevation ranges and $>1200-2000 \mathrm{~mm} \mathrm{yr}^{-1}$ for elevation above $1000 \mathrm{~m}$. These rainfall and elevation limits are generally based on those of the ecofloristic zones of the study area of FAO (1989) and the life zone system of Holdridge (1967). A climatic zone map was derived from the precipitation and elevation maps developed for the potential biomass density modeling.

The root:shoot ratios that we used are as follows: 0.18 for lowland and montane moist forests, 0.10 for lowland and montane seasonal forests, and 0.5 for lowland dry forests. Belowground biomass carbon density was then calculated for each pixel of the PCD80 and $A C D$ maps using these ratios and the climatic zones map.

\section{Carbon Density of Forest Soils}

There have been several attempts to estimate global soil carbon pools which include use of the FAOUNESCO Soil Map of the World (Bohn 1982, Eswaran et al. 1993) and the life zone system (Post et al. 1982). None of these provide a suitable spatial distribution for estimating soil carbon pools for tropical forests because they have tended to lump the soil pedon data by map units or life zones without regard to vegetation cover or other variables that vary spatially.

The FAO-UNESCO (1971-81) Soil Map of the World is the only map presently available in digital form suitable for estimating the spatial distribution of tropical soil carbon pools. Unfortunately, the accompanying soil pedon descriptions are not suitable for estimating soil carbon densities because they do not report soil bulk density needed to convert the carbon concentrations to carbon contents, not all map units have pedon descriptions, and many of the soil pedons are for non-native vegetation. To overcome these problems with the pedon data base and previous studies, we developed an alternative approach for using this map.

Based on the available spatial data bases and the known factors that influence soil carbon, we chose soil texture and climatic regime (measured by mean annual precipitation coupled with effects of decreasing evapotranspiration due to increasing elevation) as the two most important factors for our analysis. It has been suggested that soil texture can play a significant role in determining the amount of organic matter in soil (Sanchez 1976, Lugo et al. 1986, Parton et al. 1987).
Of all the environmental factors that affect the regional distribution of soil organix matter, mean annual precipitation has been shown to explain the most variance, followed by mean annual temperature (Jenny 1980).

We used the data base of Zinke et al. (1984) as a source of data on soil carbon density. This data set consists of pedon data containing information on organic carbon content (\% $\mathrm{C}$ and bulk density to various depths), generally accompanied by information on soil texture, geographic location, climatic data, and land use. To this, we added data from other sources (Brown and Lugo 1990, and data from Venezuela and Costa Rica from ongoing research by S. Brown). We extracted all the data on soil carbon density for native tropical forests that met the following criteria: (1) reported carbon to $100 \mathrm{~cm}$ depth, and (2) had sufficient data to place the pedon in a rainfall, elevation, and soil texture class.

Because of the relatively few data points that met the criteria (a total of 171 points), we stratified the data set into the same three climatic zones as those used for the below-ground biomass (see above). We also assigned all the data to one of three texture classes based on the definitions used by the FAO-UNESCO Soil Map of the World. We then calculated the mean soil carbon density for each of nine classes (three climatic zones and three texture classes). This procedure resulted in a $3 \times 3$ matrix of mean soil organic carbon densities (Table 1). Because the soil

Table 1 Mean soil organic carbon contents to $100 \mathrm{~cm}\left(\mathrm{Mg} \mathrm{ha}^{-1}\right.$, with one SE and sample size in parentheses) stratified by texture and climatic regimes, to generate the spatial distribution of soil carbon density in forest soils of tropical Asia. See text for further details on sources.

\begin{tabular}{|c|c|c|c|}
\hline \multirow{2}{*}{$\begin{array}{l}\text { Texture } \\
\text { classes }\end{array}$} & \multicolumn{3}{|c|}{ Climatic regime* } \\
\hline & Dry & Seasonal & Moist \\
\hline Coarse & $94(30,4)$ & $63(9,10)$ & $77(19,10)$ \\
\hline Medium & $97(9,18)$ & $136(21,20)$ & $147(27,20)$ \\
\hline Fine & $150(24,11)$ & $151(14,25)$ & $116(9,53)$ \\
\hline Medium-coarse $\S$ & 96 & 100 & 111 \\
\hline Medium-fine§ & 124 & 144 & 131 \\
\hline Histosols $\mathbb{I}$ & & -675 & \\
\hline
\end{tabular}

*Dry (lowland) $=\leq 1200 \mathrm{~mm}$ yr $^{-1}$ with elevation below $1000 \mathrm{~m}$, seasonal (lowland and montane) $=>1200-2000 \mathrm{~mm} \mathrm{yr}^{-1}$ and elevation below $1000 \mathrm{~m}$ or $500-1200 \mathrm{~mm} \mathrm{yr}^{-1}$ and elevation above $1000 \mathrm{~m}$, and moist (lowland and montane) $=>2000$ $\mathrm{mm} \mathrm{yr}^{1}$ over all elevation ranges or $>1200-2000 \mathrm{~mm} \mathrm{yr}^{-1}$ and elevation above $1000 \mathrm{~m}$.

$\S$ These are mixed classes, and are calculated as the arithmetic average of the two corresponding classes TFrom data in Anderson (1983); we used a bulk density of peat soils of $0.15 \mathrm{~g} / \mathrm{cm}^{3}$, a carbon concentration of $45 \%$, and a depth of $100 \mathrm{~cm}$. 
map also contained two mixed texture classes (medium-fine and medium-coarse), we estimated their carbon density as the arithmetic average of the two corresponding classes. There are also fairly extensive areas of histosols in tropical Asia, usually associated with peat swamps (Anderson 1983). These peat deposits generally exceed $100 \mathrm{~cm}$ in depth. We estimated their carbon density from data given in Anderson (1983, cf. Table 1).

We then used the map of soil texture classes derived from the FAO-UNESCO Soil Map of the World, the climatic zone map, and the values in Table 1 to assign each pixel the corresponding soil carbon density. Finally, we overlayed the forest maps derived above to produce a spatial distribution of soil carbon density in the forest existing in 1980 . We assumed that soil carbon density under forests did not change as a result of degradation of biomass carbon density.

\section{Results and Discussion}

\section{Validation of the Models to Estimate Carbon Densities}

As few forests of any significant extent in tropical Asia are undisturbed by humans (Brown et al. 1991, Collins et al. 1991, Whitmore 1984), it is difficult to validate our estimates of potential biomass carbon density. The only suitable data for validating our model are large-scale inventories in mature forests and such data do not exist. Furthermore, small-scale field data would not be suitable for validating our model because many of the input data are of coarse resolution. To determine if our results seemed reasonable and gave expected trends across the region, we aggregated our estimates by the ecofloristic zones (EFZ) for the region (FAO 1989). These zones served as an independent data base for testing our results because we have not used this map in any of our analysis.

An EFZ is based first on bio-climatic factors such as rainfall and its seasonality, the length of the dry season, relative humidity, and temperature. Elevation, soils, and dominant characteristic flora add further levels of detail. This map serves as an approximate potential vegetation map for the region. The FAO map (obtained in digital form from K.D. Singh, FAO, Rome) was prepared by the Forestry Department of the FAO and the International Institute of Vegetation Mapping in Toulouse, France. We reclassified the original 36 zones into six zones. These consisted of three lowland $(<1500$ $\mathrm{m})$ and three montane $(>1500 \mathrm{~m})$ zones, subdivided further into moist- evergreen forests with high nonseasonal rainfall, semideciduous forests with seasonal precipitation, and dry-deciduous forests with a long dry season and low rainfall.

Overlaying the reclassified EFZ map with the one of PCD-80 produced expected trends (Table 2). Our potential biomass carbon density estimates were higher for forests in lowland than in montane zones for a given moisture regime, and higher in moist followed by seasonal and dry for a given elevation belt. These expected patterns of potential biomass carbon density with EFZ increase our confidence that the methodology described here does produce reasonable estimates at this regional scale.

As so few forest inventory data were available for

Table 2 Estimates of mean biomass carbon and soil carbon density (to $100 \mathrm{~cm}$ depth) $\left(\mathrm{Mg} \mathrm{C}^{-1}\right.$ ) potentially (PCD-80) and actually (ACD) in forests of tropical Asia by ecofloristic zones, for 1980 . Coefficients of variation (CV, in \%) are given for total potential and actual biomass carbon and soil carbon densities.

\begin{tabular}{|c|c|c|c|c|c|c|c|c|c|c|c|}
\hline \multirow{2}{*}{$\begin{array}{l}\text { Ecofloristic } \\
\text { zone* }\end{array}$} & \multicolumn{2}{|c|}{ PCD-80 } & \multirow[b]{2}{*}{ Total } & \multirow[b]{2}{*}{$\mathrm{CV}$} & \multicolumn{4}{|c|}{$A C D$} & \multirow[b]{2}{*}{ Soil } & \multirow[b]{2}{*}{ CV } & \multirow{2}{*}{$\begin{array}{l}\text { Total } \\
1980\end{array}$} \\
\hline & Above & Below & & & Above & Below & Total & $\mathrm{CV}$ & & & \\
\hline \multicolumn{12}{|c|}{ CONTINENTAL } \\
\hline L-moist & 224 & 41 & 265 & 16 & 117 & 21 & 138 & 25 & 133 & 11 & 271 \\
\hline L-seasonal & 175 & 18 & 193 & 19 & 94 & 9 & 103 & 54 & 121 & 25 & 224 \\
\hline L-dry & 124 & 63 & 187 & 29 & 38 & 19 & 57 & 61 & 121 & 22 & 178 \\
\hline M-moist & 176 & 32 & 208 & 21 & 115 & 20 & 135 & 25 & 135 & 7 & 270 \\
\hline M-seasonal & 152 & 16 & 168 & 39 & 83 & 8 & 91 & 51 & 125 & 23 & 216 \\
\hline Wtd mean & \multicolumn{11}{|c|}{ INSULAR } \\
\hline L-moist & 270 & 49 & 319 & 9 & 162 & 29 & 191 & 23 & 187 & 102 & 378 \\
\hline L-seasonal & 232 & 22 & 254 & 15 & 88 & 8 & 96 & 46 & 142 & 65 & 238 \\
\hline M-moist & 251 & 45 & 296 & 16 & 152 & 28 & 180 & 27 & 114 & 21 & 294 \\
\hline $\begin{array}{l}\text { Wtd mean } \\
\text { Wtd mean } \\
\text { for region }\end{array}$ & $\begin{array}{l}268 \\
219\end{array}$ & $\begin{array}{l}48 \\
36\end{array}$ & $\begin{array}{l}316 \\
255\end{array}$ & & $\begin{array}{l}162 \\
124\end{array}$ & $\begin{array}{l}28 \\
20\end{array}$ & $\begin{array}{l}190 \\
144\end{array}$ & & $\begin{array}{l}178 \\
148\end{array}$ & & $\begin{array}{l}368 \\
292\end{array}$ \\
\hline
\end{tabular}

*Forests were not found in all zones in $1980 ; \mathrm{L}=$ lowland, $\mathrm{M}=$ montane. 
developing the degradation models, we were forced to use all of them which left none for validating our estimates of actual biomass carbon density. However, because other data bases were used, in addition to the degradation ratio/population density regression equations, to develop the actual biomass carbon density estimates, we believe that we can use the inventory data to check the overall validity of the results. We fit a linear regression equation between the actual biomass carbon density from the inventory data and the predicted carbon density from the model. A significant relationship was obtained with an $r^{2}$ of 0.7 , a slope of 0.91 , and an intercept of 7.2. The reduction in $r^{2}$ was caused mainly by five points from the dry and seasonal zones of continental Asia where the model predicted higher biomass carbon densities than was obtained from the inventories. This pattern could be expected because the original regression equations for these two zones had the lowest $r^{2}$ (Fig. 1). Overall, the model tended to overestimate the biomass carbon density by $<5 \%$ for densities $<250 \mathrm{Mg} \mathrm{ha}{ }^{-1}$ and up to $8 \%$ for densities between $250-400 \mathrm{Mg} \mathrm{ha}^{-1}$.

Despite the coarse resolution of many of the data layers, the imperfect regression equations, the problems with inadequate biomass density data, and the many assumptions used, we believe that the map of actual biomass carbon density is a realistic spatial representation of the situation in 1980 and the best that can be produced with current technology and data. For the first time, we have produced a spatially explicit estimate of carbon density which considers distributions of environmental and anthropogenic factors.

\section{Geographical Distribution of Biomass and Soil Carbon Densities}

Actual biomass carbon densities range from less than 50 to more than $360 \mathrm{Mg} \mathrm{ha}^{-1}$ for the forests of tropical Asia (Fig. 2). Most of the forests of the region have biomass carbon densities that range from 100 to $200 \mathrm{Mg} \mathrm{ha}{ }^{-1}$. Forests with low biomass carbon densities ( $<100 \mathrm{Mg} \mathrm{ha}^{-1}$ ) are generally located in India and Thailand, while forests with high biomass carbon densities ( $>250 \mathrm{Mg} \mathrm{ha}^{-1}$ ) are located in the countries on the island of Borneo and Irian Jaya.

Carbon densities of soils range mostly from 60 to $160 \mathrm{Mg} \mathrm{ha}^{-1}$ (Fig. 3). In general, the soils of continental Asia have higher carbon densities (120-160 Mg ha-1) than those in insular Asia (100-120 $\left.\mathrm{Mg} \mathrm{ha}^{-1}\right)$, with the exception of patches of peat soils $\left(675 \mathrm{Mg} \mathrm{ha}^{-1}\right)$. Furthermore, for most of the forested areas, the soil carbon densities are similar in value to the biomass carbon densities.

\section{Biomass and Soil Carbon Densities}

\section{By Ecofloristic Zone}

Potential and actual biomass carbon density. The average biomass carbon density by ecofloristic zones ranges from 168 to $319 \mathrm{Mg} \mathrm{C} \mathrm{ha}^{-1}$ for the total potential and from 57 to $191 \mathrm{Mg} \mathrm{C} \mathrm{ha}^{-1}$ for the total actual (Table 2). The total potential biomass carbon density for a given ecofloristic zone is about 1.5 times higher in insular than in continental Asia, a trend caused by the generally more favorable environmental conditions in the insular region. The coefficients of variation for the potential biomass carbon density (CV, Table 2), indicate that the variability in carbon densities is less in lowland than in montane zones, less in the insular than in the continental region, and decreases from dry and/or seasonal to moist zones within the same elevation belt. The zones with the low CVs suggest that they are relatively environmentally homogeneous. On the other hand, lowland dry and montane seasonal ecofloristic zones are relatively more variable environmentally, and thus contain forests that are more variable with respect to biomass carbon density.

Below-ground biomass carbon density accounts for $14 \%$ of the total biomass carbon density under potential and actual conditions (Table 2). However, proportionally more of the potential and actual biomass carbon density is below-ground in insular Asia (15\% of the total) than in continental (12-13\% of the total), caused by the dominance of moist forests (root:shoot ratio of 0.18 ) in the former versus dominance of seasonal forests (rootshoot ratio of 0.10 ) in the latter area. Even though forests in the dry zone have a high root:shoot ratio $(0.5)$, they contribute very little to the regional totals because the percent of the total continental forest area in this ecofloristic zone in 1980 was small (about $5 \%$ ) and nonexistent in the insular area.

Actual biomass carbon density of existing forests in the insular and continental areas is reduced to about $60 \%$ and $53 \%$, respectively, of their potential amount (Table 2), caused by the human activities described earlier. Coefficients of variation for actual biomass carbon densities are higher than for potential densities, reflecting the uneven impact of humans on the forested landscape. The differences in the way humans impact the forests in the region is further illustrated by the differences in the degree of forest degradation that exists among ecofloristic zones between the two areas. In the continental area, lowland dry forests are the most degraded (degradation ratio of 0.30 and $\mathrm{CV}$ of $61 \%$ ), whereas in insular Asia, where the lowland dry zone is missing, the lowland seasonal forests are the most degraded (degradation ratio of 0.38 and $\mathrm{CV}$ of 
$46 \%$ ). This trend has been observed in other tropical forest zones, where the drier zones tend to be preferentially inhabited by humans and are often the first to become degraded and cleared (Tosi and Voertman 1964).

Existing forests in montane moist and seasonal zones of continental Asia are less degraded than their lowland counterparts with degradation ratios of 0.54-0.65 and 0.52-0.54, respectively. In insular Asia, however, the lowland and montane moist forests are degraded by the same amount (60\%) and less than or almost equal to the same zones in the continental area. The overall lower degradation of lowland moist forests in insular than in continental Asia is most likely caused by two factors: the population density in insular is less than in continental Asia (82 person $\mathrm{km}^{-2}$ versus 187 person $\mathrm{km}^{-2}$ ), and lowland insular forests have higher potential biomass carbon densities than continental forests (Table2).

Actual soil carbon densities. Soil carbon densities range from 114 to $187 \mathrm{Mg} \mathrm{ha}^{-1}$ (Table 2). Coefficients of variation in soil carbon densities are generally small, with the exception of the high values for the lowland moist and seasonal zones in insular Asia. The high CVs found in insular Asia are caused by the presence of peat deposits that have considerably higher soil carbon contents than any other soil class (Table 1).

In general, soil carbon density is higher than or about equal to the actual biomass carbon density in a given ecofloristic zone, except for the montane moist zone of insular Asia (ratios of soil carbon to actual biomass carbon density of $0.63-2.12$ ). This overall correlation is to be expected as the environmental conditions that favor high plant biomass are the same as those that produce high soil carbon. Furthermore, as expected, soil carbon density in moist zones is higher than in seasonal or dry zones (Post et al. 1982), and a tendency to be higher in montane zones than in lowland zones of the continent. The exception is the montane moist zone of insular Asia which has the lowest soil

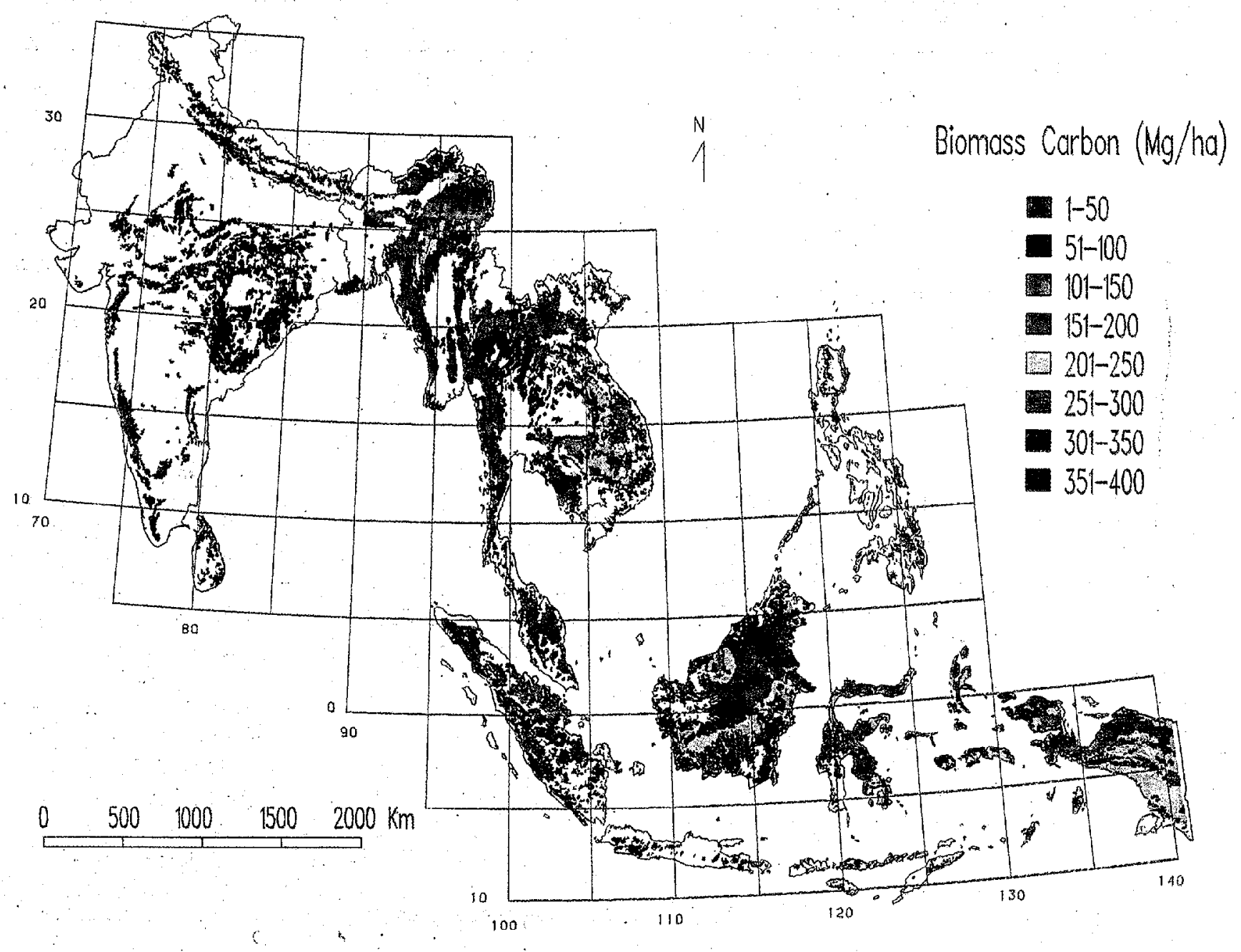

Figure 2 Spatial distribution of biomass carbon density, above- and below-ground in $50 \mathrm{Mg}$ ha-1 classes, for forests of tropical Asia in 1980 . 
carbon density of all, a value that corresponds to the mean carbon content for fine textured soils in this ecofloristic zone (cf. Table 1).

The higher soil carbon density of the lowland moist zone in insular compared to continental Asia is caused by the relatively large areas of peat forests in the former area which have very high soil carbon densities (cf. Table 1 and Fig. 2). The difference between the lowland seasonal zone of the continental versus insular areas reflects differences in the common texture class; soils in this zone in insular Asia are dominated by fine textured soils whereas those in continental Asia are dominated by coarse to medium-coarse soils.

As we assumed no reduction of soil carbon density caused by forest degradation, the soil carbon contents in Table 2 could be lower, particularly in those zones where biomass carbon density is reduced the most from its potential (e.g., lowland dry in continental and lowland seasonal in insular). From data given in Detwiler (1986) for shifting cultivation forests, we estimated that the reduction could amount to about 5 to $10 \%$ of the mean soil carbon density in these two ecofloristic zones. But as the forests in these two zones occupy a small proportion of the total area, the effect of our assumption on the total soil carbon pools is very small $(<0.5 \%)$.

Total carbon density of vegetation and soil in 1980. When the soil carbon density is included, the variation in the total carbon density (vegetation plus soil) among ecofloristic zones is reduced, ranging from 178 to $378 \mathrm{Mg} \mathrm{ha}^{-1}$. The difference between the minimum and maximum biomass carbon density by EFZ for the whole region is more than a three-fold factor, but the difference between the minimum and maximum total carbon density is about two-fold (Table 2). The area-weighted mean total carbon density in forests of insular Asia ( $368 \mathrm{Mg} \mathrm{ha}^{-1}$ ) is more than 1.5 times higher than that in forests of continental Asia (239 $\mathrm{Mg} \mathrm{ha}^{-1}$ ).

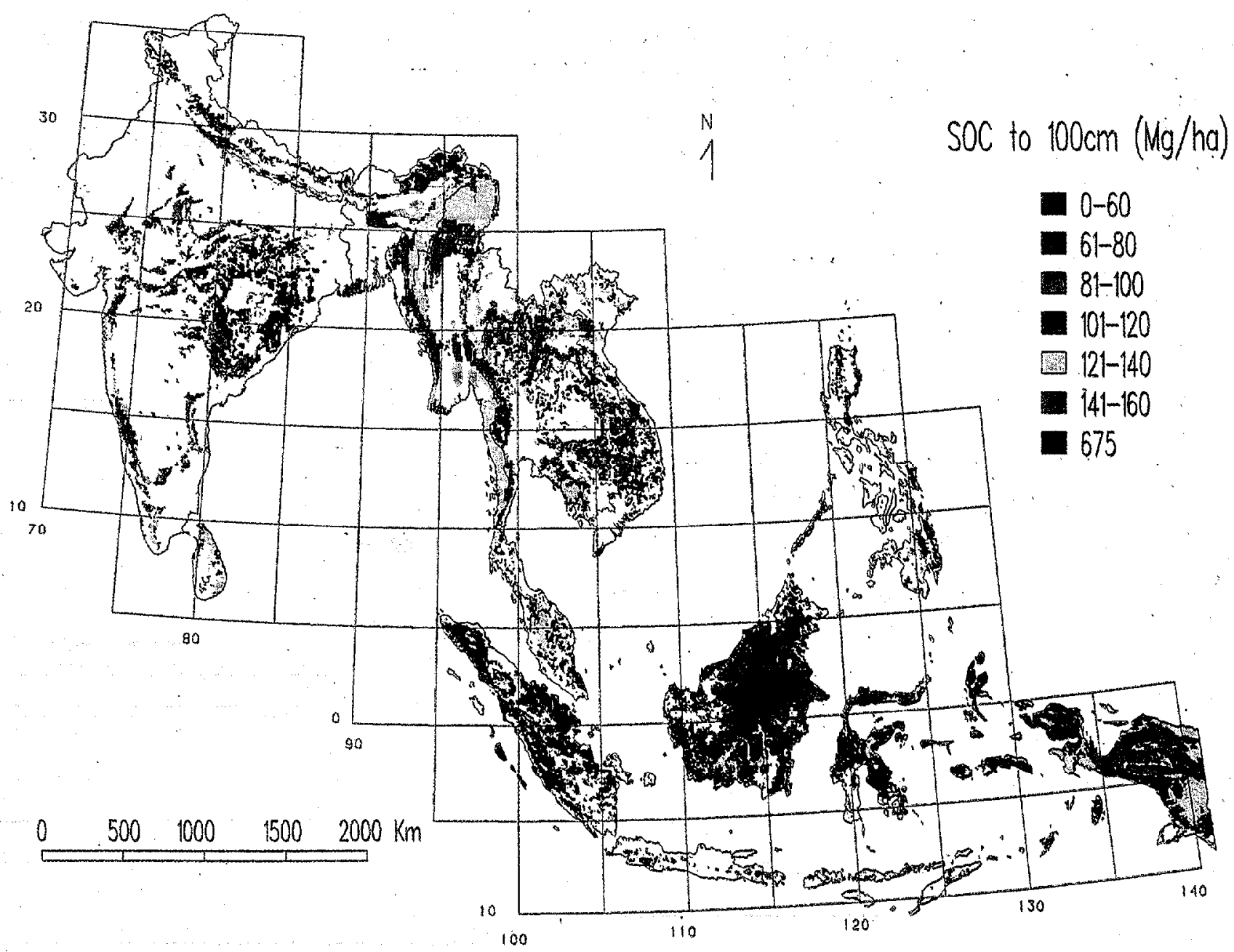

Figure 3 Spatial distribution of soil carbon density (SOC) to $100 \mathrm{~cm}$ depth in $20 \mathrm{Mg} \mathrm{ha}{ }^{-1}$ classes for forests of tropical Asia in 1980 . 


\section{By Country}

Potential and actual biomass carbon density. Potential biomass carbon density averages $255 \mathrm{Mg}$ $\mathrm{ha}^{-1}$ for all of tropical Asia, and ranges from a low of $188 \mathrm{Mg} \mathrm{ha} a^{-1}$ in Nepal to a high of about $340 \mathrm{Mg} \mathrm{ha}{ }^{-1}$ in Brunei (Table 3), reflecting the differential spread of environmental factors. The corresponding $\mathrm{CVs}$ by country tend to be low (4-25\%) with India being the most variable as expected for this large country with a wide range of environmental conditions.

Highest potential carbon density values are in those countries which contain forests dominated by species of dipterocarp: Brunei, Indonesia, Malaysia (Peninsular, Sabah and Sarawak), and the Philippines (Whitmore 1984) and whose climate is dominated by moist conditions. Countries with low biomass carbon densities, e.g., India, Laos, Nepal, and Thailand, are dominated by seasonal to dry climates.

Countries where the biomass carbon density of forests is reduced the most from their potential by human activities are Bangladesh, India, Nepal, and Peninsular Malaysia (a degradation ratio of about 0.380.41 ). The degradation ratios for the first three countries are caused by the high population densities (132-629 persons $\mathrm{km}^{-2}$ ) within and around the relatively few remaining forests (cf. Fig. 1) and their forests have low biomass carbon densities (77-101 $\mathrm{Mg} \mathrm{ha}^{-1}$; Table 3). Although the carbon density of forests in Peninsular Malaysia is considerably lower than its potential because of a high population density ( 205 persons $\mathrm{km}^{-2}$, the fourth most densely populated country of the whole region), compared to the other three countries the forests still contain a considerable quantity of biomass carbon ( $\left.125 \mathrm{Mg} \mathrm{ha}^{-1}\right)$. The above-ground value for Peninsular Malaysia is well within the $95 \%$ confidence interval of the average carbon density based on a nation-wide forest inventory in 1980 (Brown $e t$ al. 1994). Most of the reduction in forest biomass in this country is caused by extensive logging and log poaching.

Countries whose forests are the least degraded from their potential are Brunei, Cambodia, Indonesia, Laos, Myanmar, Sabah/Sarawak, and Vietnam (degradation ratios of $0.6-0.8$ ). The carbon density of the forests of the remaining countries is $50 \%$ or less of their potential. The different rankings of actual compared to the potential biomass carbon density by country can be attributed to differences in the distribution of human populations and potential biomass carbon density.

Two other estimates of actual biomass densities of forests have recently been made for the countries in tropical Asia. The first one is part of the Tropical Forest Resource Assessment 1990 Project of the Food and Agriculture Organization. Their estimates of above-ground biomass carbon density (we converted their biomass estimates to carbon units) for the same countries that we include range from about 47 to 148 $\mathrm{Mg} \mathrm{ha}^{-1}$ for 1990 (K.D. Singh, 1993, FAO, pers. comm.) comared to our range of 66 to $169 \mathrm{Mg} \mathrm{ha}^{-1}$ for 1980 . The FAO estimates were obtained by converting average forest volumes obtained from partial-country forest inventories to biomass units and extrapolating to the whole country. On average the $\mathrm{FAO}$ values are about $75 \%$ of ours. The lower values obtained by FAO could

Table 3 Estimates of mean biomass carbon and soil carbon density, to $100 \mathrm{~cm}$ depth, (Mg C ha- ${ }^{-1}$ potentially (PCD-80) and actually (ACD) in forests of tropical Asia by country, for 1980. Coefficients of variation (CV, in \%) are given for total potential and actual biomass carbon and soil carbon densities.

\begin{tabular}{|c|c|c|c|c|c|c|c|c|c|c|c|}
\hline \multirow[b]{2}{*}{ Country } & \multicolumn{4}{|c|}{ PCD-80 } & \multicolumn{4}{|c|}{$A C D$} & \multirow[b]{2}{*}{ Soil } & \multirow[b]{2}{*}{$C V$} & \multirow{2}{*}{$\begin{array}{l}\text { Total } \\
1980\end{array}$} \\
\hline & Above & Below & Total & $\mathrm{CV}$ & Above & Below & Total & $\mathrm{CV}$ & & & \\
\hline Bangladesh & 232 & 35 & 267 & 16 & 87 & 14 & 101 & 32 & 143 & 8 & 244 \\
\hline Brunei & 289 & 52 & 341 & 6 & 160 & 29 & 189 & 8 & 305 & 88 & 494 \\
\hline Cambodia & 209 & 24 & 233 & 13 & 153 & 17 & 170 & 24 & 129 & 15 & 299 \\
\hline India & 173 & 28 & 201 & 28 & 66 & 11 & 77 & 58 & 115 & 29 & 192 \\
\hline Indonesia & 266 & 49 & 315 & 11 & 162 & 28 & 190 & 24 & 183. & 101 & 373 \\
\hline Laos & 171 & 23 & 194 & 17 & 137 & 19 & 156 & 24 & 136 & 10 & 292 \\
\hline \multicolumn{12}{|l|}{ Malaysia: } \\
\hline Peninsular & 258 & 47 & 305 & 10 & 106 & 19 & 125 & 20 & 127 & 12 & 252 \\
\hline Sabah/Sarawak & 285 & 52 & 337 & 4 & 169 & 31 & 200 & 13 & 162 & 100 & 362 \\
\hline Myanmar & 193 & 30 & 223 & 23 & 120 & 18 & 138 & 25 & 136 & 6 & 274 \\
\hline Nepal & 167 & 21 & 188 & 21 & 70 & 8 & 78 & 47 & 125 & 20 & 203 \\
\hline Philippines & 255 & 46 & 301 & 12 & 110 & 19 & 129 & 16 & 112 & 6 & 241 \\
\hline Sri Lanka & 206 & 24 & 230 & 18 & 102 & 12 & 114 & 34 & 124 & 20 & 238 \\
\hline Thailand & 177 & 23 & 200 & 23 & 94 & 12 & 106 & 31 & 128 & 16 & 234 \\
\hline Vietnam & 186 & 26 & 212 & 15 & 132 & 19 & 151 & 23 & 134 & 14 & 285 \\
\hline Wtd mean & 219 & 36 & 255 & & 124 & 20 & 144 & & 148 & & 292 \\
\hline
\end{tabular}


partially be explained by continued degradation of the forests by the increasing population in the intervening period as well as by differences in methods.

A study by Flint and Richards (1994) produced weighted estimates of total biomass carbon density for forests and woodlands for 1980 of $74 \mathrm{Mg} \mathrm{ha}^{-1}$ for continental countries and $124 \mathrm{Mg} \mathrm{ha}^{-1}$ for insular countries. These are both $65 \%$ of our corresponding values, and about $80-90 \%$ of FAO's corresponding values, after subtracting below-ground biomass. Flint and Richards' estimates are based on compiling data from the forestry literature for the regions and applying degradation factors based on human populations. similar to but not the same as our approach.

Although differences exist among ours and the other two estimates, the three sets of values are similar in magnitude to each other. Differences in methodology, sources of input data, and time of the assessment are most likely the causes for the differences. Despite these differences in approach, the general similarity of estimates provides compelling evidence that the forests of the tropical Asian countries have generally low biomass carbon densities.

Actual soil carbon densities. Countries with the highest soil carbon densities (162-305 $\mathrm{Mg} \mathrm{ha}^{-1}$ ) are those with proportionally large areas of peat swamps, e.g., Brunei, Indonesia, and Sabah/Sarawak (Fig. 3). Soil carbon densities vary little among the other countries (115-143 $\left.\mathrm{Mg} \mathrm{ha}^{-1}\right)$. As a result, the differences in the total carbon density (soil plus vegetation) among countries is reduced to a two-fold factor between the minimum and maximum value, excluding Brunei which has the highest soil and a high biomass carbon density.

\section{Total Carbon Pools}

The distribution of total carbon by ecofloristic zone is shown in Figure 4. The total carbon pool is concentrated in only one to two ecofloristic zones in each region. For continental Asia, most of the total carbon in soil, potential biomass, and actual biomass (about $80 \%$ for each) is concentrated in the lowland seasonal and moist forests (Fig. 4a). This distribution is caused mainly by (1) the large area of seasonal forests in the continental region ( $54 \%$ of the total forest area) and (2) the high carbon densities along with the relatively large area of lowland moist forests ( $25 \%$ of the total forest area). For the lowland seasonal zone in 1980, the carbon in soils represents a slightly larger proportion of the total carbon pool $(54 \%)$ than the carbon in biomass ( $46 \%$ ). In the lowland moist zone, the carbon is about equally divided between soil and biomass. With respect to the total potential carbon pool (soil plus potential biomass carbon), soil accounts for only $39 \%$ and $33 \%$ of the total in the lowland seasonal and moist zones, respectively.

The third most important ecofloristic zone in continental Asia, the montane moist, accounts for only $14 \%$ of the total soil and potential and actual biomass carbon (Fig. 4a). Once again, the total carbon pool in this zone in 1980 is divided equally between the soil and biomass. Forests in lowland dry and montane seasonal zones contribute very little to the total pool.

Insular Asia is dominated by the lowland moist zone, which accounts for $86 \%$ of the total area and 89 to $92 \%$ of the total carbon pool in biomass and soil (Fig. $4 b)$. The remaining area and carbon is located in the montane moist zone; other lowland and montane zones are practically non-existent. The carbon pool in the lowland moist zone in 1980 is divided equally between biomass and soil. However, with no forest biomass degradation (potential biomass), the soil carbon pool would comprise $37 \%$ of the total pool, a lower proportion than the actual. In the montane moist zone, more of the carbon is located in the actual $(61 \%)$ and potential ( $72 \%)$ biomass than in the soil.
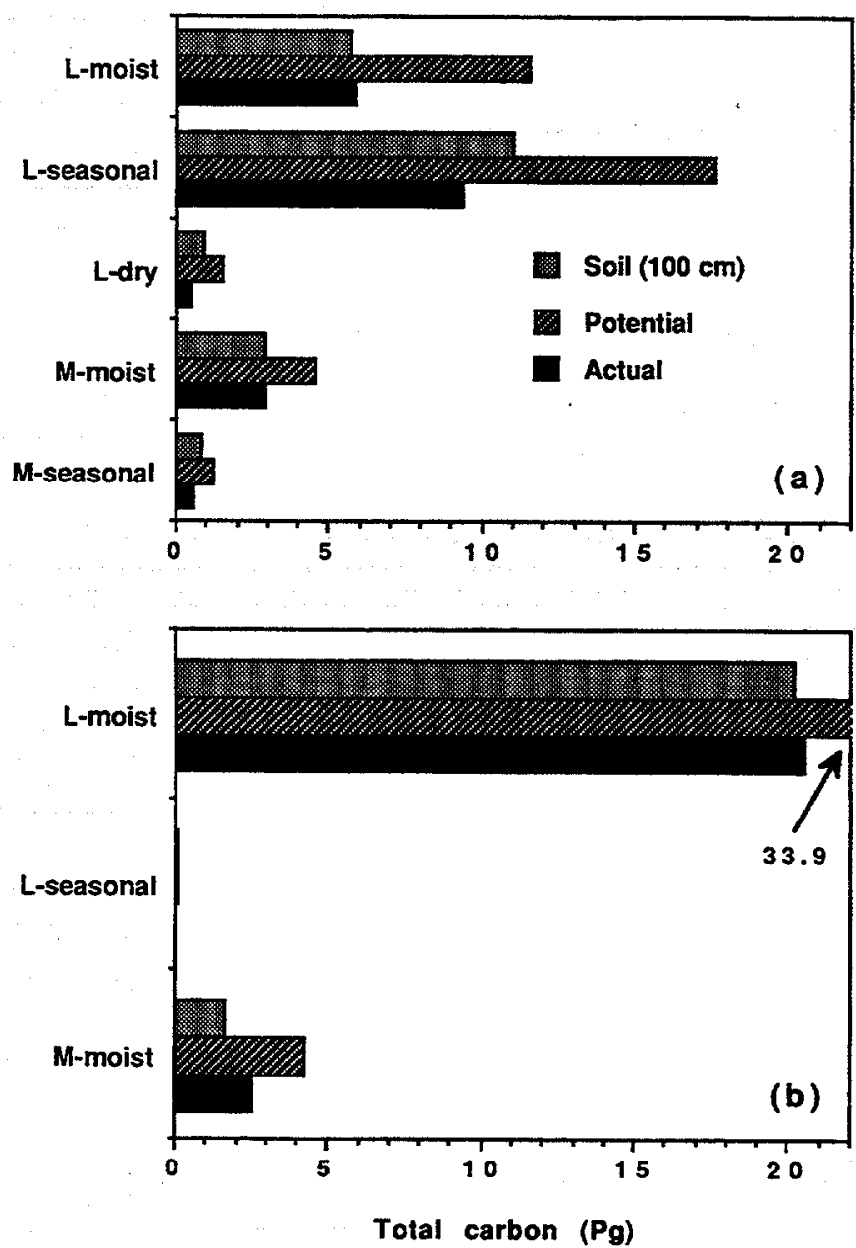

Figure 4 Total carbon content in soils and and potential and actual forest vegetation for (a) continental and (b) insular Asia by ecofloristic zones for $1980 . \mathrm{L}=$ lowland and $\mathrm{M}=$ montane. 
Although it is often stated that tropical soils contain low amounts of soil carbon (or organic matter), our results clearly show that it is of equal importance to the total 1980 carbon pool as the forest biomass (Fig. 4). In fact, the soil carbon content generally exceeded that in the vegetation in zones where precipitation was low or seasonal in nature (Table 2 and Fig. 4a). Compared to the potential carbon pool however, soil carbon is of lesser importance.

Three countries of tropical Asia (Indonesia, India, and Myanmar) account for about 71 to $75 \%$ of the total carbon pool in potential biomass (a total of $53 \mathrm{Pg}$ ), actual biomass (a total of $30 \mathrm{Pg}$ ) and soil (a total of 32 Pg) (Fig. 5). However, there are differences in the allocation of the carbon between actual biomass, potential biomass, and soil among these three countries. In Indonesia, the country with by far the largest amount of total carbon in 1980 (40 Pg), and Myanmar, soil carbon accounts for $50 \%$ of the actual total and $39 \%$ of the potential total. For the drier country of India, $60 \%$ of the 1980 total and $36 \%$ of the potential total is in soil.

The next most important countries to the regional total are Cambodia, Laos, Sabah/Sarawak, and Thailand, which together account for $19-24 \%$ of the total soil and potential and actual biomass carbon. In these countries, the contribution of soil to the total actual pool is generally less than the biomass, except for Thailand (Fig. 5). The remaining seven countries compose about $7 \%$ of the total pools.

\section{Total Region}

The region as a whole has a carbon pool of $43 \mathrm{Pg}$ in soil, $74 \mathrm{Pg}$ in potential biomass, and $42 \mathrm{Pg}$ in actual biomass of forests (Fig. 6). The distribution is split remarkably even between continental and insular Asia. Even though continental Asia contains $58 \%$ of the the total forest cover in 1980, these forests contain somewhat less than their actual and potential share of the carbon. Continental Asian countries account for $50 \%$ of the soil pool, $49 \%$ of the potential biomass pool, and $45 \%$ of the actual biomass pool. This distribution of carbon is, of course, caused by the geographic variations in climatic regimes and soil texture classes, which influence the biomass and soil carbon densities, as well as the distribution of human populations.

\section{Sources of Error}

In this paper we have presented estimates of the amount and distribution of carbon in vegetation and soils for the forest area in tropical Asia. These estimates are subject to error owing to both methodology and data limitations. As new data (quality and resolution) become available, we can build on our approach to reduce further the uncertainties and to improve the accuracy and precision of our carbon density estimates.

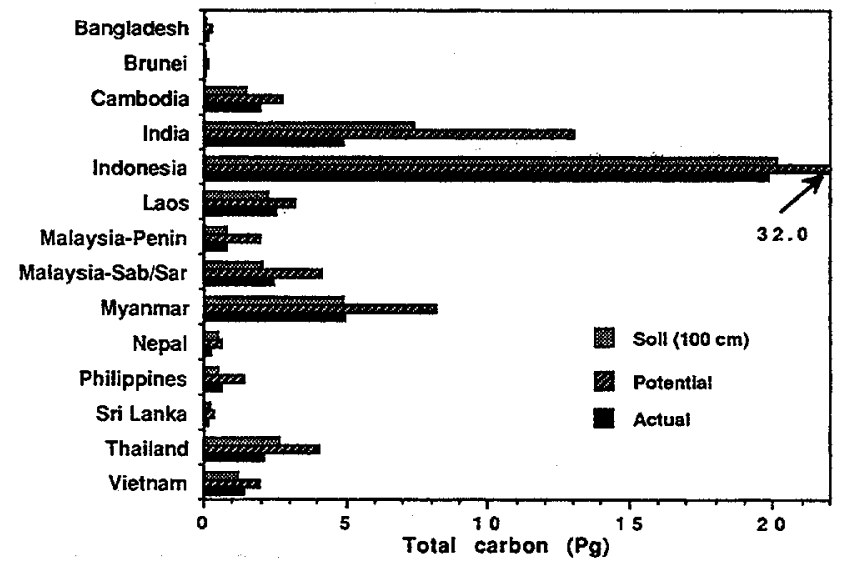

Figure 5 Total carbon content in soils and potential and actual forest vegetation for continental and insular Asian countries for 1980. Malaysia-Penin = Peninsular Malaysia, and Malaysia-Sab $/$ Sar = Sabah and Sarawak, the western states of Malaysia.

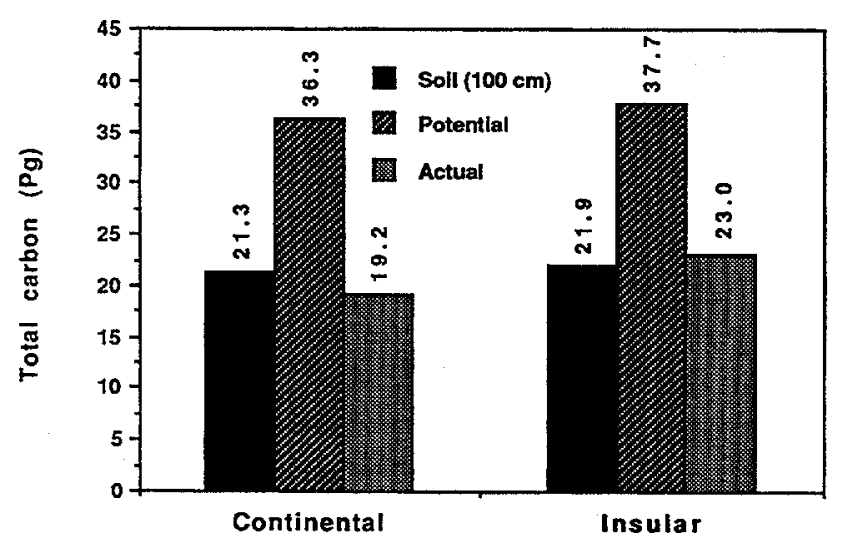

Figure 6 Total carbon content in soils and potential and actual forest vegetation of the continental and insular Asian forests for 1980 .

At this stage in the analysis, we recognize that errors originate from several sources. First, there is the inherent error in the spatial data bases caused by inaccuracies in the maps, or maps of insufficient detail (e.g., vegetation and soil maps). We have limited control over these errors, and foresee little improvement in these data bases in the near future because of the large-scale effort needed to revise and update vegetation and soils maps. However, when improved data are developed, we expect that the methodology presented here can be repeated to obtain improved spatially explicit estimates of biomass density.

A second potential source of error is in the production of maps from the interpolation of point data (e.g., precipitation, climate index and population density maps). However, we believe that these errors are minimal because of the two-dimensional interpolation methods that we used that produced results comparable with other ancillary maps and 
information about the region (Iverson et al. 1994).

Third, there is the potential for systematic errors in the modeling of potential biomass carbon density caused by inappropriate weighting schemes for the input variables. However, we scale several of our input variables into varying-width classes before we weight them which we believe minimized this source of error.

There is also the potential that we have overlooked other factors that may be important in regulating potential and actual forest biomass. For example, we did not consider differences between broadleaf and conifer species, distances from roads and other access points, differences among human impacts (e.g., logging versus shifting cultivation), and the effects of natural disturbances. For the tropical Asian region, we believe that most of these other factors are of limited importance at the scale at which we are modeling.

Finally, there is error associated with applying imperfect regression equations across the region. This type of error applies to the degradation index versus population density equations where r-squares were low in some cases. We expect this source of error to be reduced as new forest inventories suitable for estimating biomass density become available.

Although forest biomass and soil carbon are the major contributors to the total carbon densities and carbon pools, we have not included other forest components and processes which influence these totals (e.g., understory and fine and coarse litter). Including these other components could add up to an additional $20-30 \%$ of the total biomass carbon density, particularly in dense forests in the moist zones (Brown and Lugo 1992). What effect the common human practice of using these components for fuel and fodder have on their quantities is unknown, but would likely be highly variable depending on the culture, economics, and density of the population. Also, these minor components would be expected to differ by status of the forest, e.g., mature or slightly degraded forests would probably contain more carbon in these components than highly degraded or secondary forests. Futhermore, we did not degrade the soil carbon pool under degraded forests which could reduce the total soil pools, but as discussed above, we expect this error to be small.

Taking all these sources of error into consideration, we believe that the estimates for carbon densities and pools in the forests of tropical Asia presented in this paper are conceptually correct and the best available in map form at this time.

\section{Implications for the Global Carbon Cycle}

The most obvious value of our results to the global carbon cycle is that carbon densities are represented spatially and thus can be "matched" to spatial representations of land-use change determined from satellite imagery. Progress in developing better data bases on changes in forest cover is being made as more countries are being analyzed with high resolution satellite imagery (Skole and Tucker 1993, J. Townshend, University of Maryland, 1992, pers. comm.). Improved land-use change data with our spatial estimates of carbon densities will definitely reduce the uncertainties associated with flux from the tropics as has been shown for Latin America (Houghton et al. 1991).

Our research also shows that in addition to outright forest clearing, there is another mechanism that reduces the carbon content of forests, namely biomass degradation. Most forests being cleared are not mature or primary as is often assumed, but they generally have considerably lower carbon densities than the values that have been used in terrestrial carbon models (e.g., Houghton et al. 1987). The impact of forest biomass degradation on carbon flux estimates from the tropics depends on whether the biomass removed is burned as fuel or is going into long-term storages as wood products. As most of the activities that cause forest degradation are illicit, it will be difficult to resolve this issue.

Another important implication of our results for the global carbon cycle is in the area of carbon mitigation. As stated above, it is generally assumed that tropical forests are mature and thus in steady state with respect to carbon accumulation (Lugo and Brown 1992). When mitigation options through forest management are sought, attention is usually given to the notion of establishing plantations on degraded lands (Grainger 1990). Establishing sufficient areas of plantations to significantly reduce atmospheric carbon dioxide would entail planting vast areas, which would probably not be feasible at this time (Grainger 1990). However, because we have shown that many forests in tropical Asia are far from their maximum carbon stock, protection of these forests could sequester significant quantities of carbon by natural regeneration and regrowth (Iverson et al. 1994). How feasible this forest management option will be in the future depends on the global willingness and commitment to reduce fluxes and levels of atmospheric carbon dioxide.

\section{Acknowledgements}

This research was supported by a grant from US Department of Energy, DOE DEFG02-90ER61081, to the University of Illinois, S. Brown, L. Iverson and A.E. Lugo, principal investigators. We thank K.D. Singh, M. Lorenzini, and E. Ataman of the Food and Agriculture Organization, Rome and $\mathrm{R}$. Witt and $\mathrm{O}$ Hebin of the UNEP/GRID, Geneva, for providing many 
of the digital data bases for this project. We also thank two anonymous reviewers for their helpful comments on this paper.

\section{References}

Ajtay, G.L., P. Ketner, and P. Duvignead. Terrestrial primary production and phytomass. In B. Bolin, E.T. Degens, S. Kempe, and P. Ketner (eds.), SCOPE-13-the global carbon cycle, J. Wiley and Sons, New York, pp. 129-182, 1979.

Anderson, J.A.R. The tropical peat swamps of western Malesia. In A.J.P. Gore (ed.), Mires: swamp, bog, fen and moor, Ecosystems of the World 4B, Elsevier Scientific Publishing Company, New York, pp. 181-200, 1983.

Bohn, H.L. Estimate of organic carbon in world soils: II. Soil Science Society of America Journal 46: 1118-1119, 1982.

Brown, S. and L.R. Iverson. Biomass estimates for tropical forests. World Resource Review 4: 366-384, 1992.

Brown, S. and A.E. Lugo. Storage and production of organic matter in tropical forests and their role in the global carbon cycle. Biotropica 14: 161-187. 1982.

Brown, S. and A.E. Lugo. Effects of forest clearing and succession on the carbon and nitrogen content of soils in Puerto Rico and US Virgin Islands. Plant and Soil 124: 5364,1990 .

Brown, S. and A.E. Lugo. Aboveground biomass estimates for tropical moist forests of the Brazilian Amazon. Interciencia 17: 8-18, 1992.

Brown, S., A.J.R. Gillespie, and A.E. Lugo. Biomass estimation methods for tropical forests with applications to forest inventory data. Forest Science 35: 881-902, 1989.

Brown, S., A.J.R. Gillespie, and A.E. Lugo. Biomass of tropical forests of south and southeast Asia. Canadian Journal of Forest Research 21: 111-117, 1991.

Brown, S., L.R. Iverson, and A.E. Lugo. Land-use and biomass changes in forests of Peninsular Malaysia from 1972 to 1982: a GIS approach. In V. Dale (ed), Effects of land use change on atmospheric $\mathrm{CO} 2$ concentrations: Southeast Asia as a case study, Springer Verlag, New York, Ch. 4, 1994.

Collins, M., J.A. Sayer, and T.C. Whitmore (eds.). The conservation atlas of tropical forests: Asia and the Pacific. International Union of Conservation and Nature, Simon and Shuster, New York, 1991.

Detwiler, R.P. Land use change and the global carbon cycle: the role of tropical soils. Biogeochemistry 2:67-93, 1986.

Detwiler, R.P. and C.A.S. Hall. Tropical forests and the global carbon cycle. Science 239:42-47, 1988.
Emanuel, W.R., H.H. Shugart, and M.P. Stevenson. Climatic change and the broad-scale distribution of terrestrial ecosystem complexes. Climatic Change 7: 29-43, 1985.

Eswaran, H., E. Van den Berg, and P. Reich. Organic carbon in soils of the world. Soil Science Society of America Joumal 57: 192-194, 1993.

Fearnside, P.M. Carbon emissions and sequestration in forests: case studies from seven developing countries. Volume 2: greenhouse gas emissions from deforestation in the Brazilian Amazon. LBL-32758, Energy and Environment Division, Lawrence Berkely Laboratory, Berkely, CA, 1992.

Flint, E.P. and J.F. Richards. Trends in carbon content of vegetation in South and Southeast Asia associated with changes in land use. In V. Dale (ed), Effects of land use change on atmospheric $\mathrm{CO} 2$ concentrations: Southeast Asia as a case study, Springer Verlag, New York, Ch. 6, 1994.

Food and Agriculture Organization. Soil map of the world 1:5,000,000, FAO-UNESCO, Rome, Italy, 1971-1981.

Food and Agriculture Organization. Classification and mapping of vegetation types in tropical Asia. Tropical Forest Resource Assessment 1990 Program, FAO, Rome, 1989.

Grainger, A. Modelling the impact of alternative afforestation strategies to reduce carbon dioxide emissions. In: Proceedings of the IPCC conference on tropical forestry response options to global climate change, Sao Paulo, Brazil. Report No. 20P-2003, Office of Policy Analysis, US Environmental Protection Agency, Washington, DC, pp. 95-104, 1990.

Hall, C.A.S. and J. Uhlig. Refining estimates of carbon released from tropical land-use change. Canadian Journal of Forest Research 21: 118-131, 1991.

Holdridge, L. Life zone ecology. Tropical Science Center, San Jose, Costa Rica, 1967.

Houghton, R.A. Tropical forests and climate. Paper presented at the International workshop on ecology, conservation and management of Southeast Asian rainforests, October 12-14, Kuching, Sarawak, 1992.

Houghton, R.A., R.D. Boone, J.R. Frucci, J.E. Hobbie, J.M. Melillo, C.A. Palm, B.J. Peterson, G.R. Shaver, G.M. Woodwell, B. Moore, D.L. Skole, and N. Myers. The flux of carbon from terrestrial ecosystems to the atmosphere in 1980 due to changes in land use: geographic distribution of the global flux. Tellus 39B: 122-139, 1987.

Houghton, R.A., D.L. Skole, and D.S. Lefkowitz. Changes in the landscape of Latin America between 1850 and 1985. II. Net release of $\mathrm{CO} 2$ to the atmosphere. Forest Ecology and Management 38: 193-199, 1991.

Iverson, L.R., S. Brown, A. Grainger, A. Prasad, and D. Liu. 
Carbon sequestration in tropical Asia: an assessment of technically suitable forest lands using geographic information systems analysis. Climate Research 3:23-38, 1993.

Iverson, L.R., S. Brown, A. Prasad, H. Mitasova, A.J.R. Gillespie, and A.E. Lugo. Use of GIS for estimating potential and actual biomass for continental South and and Southeast Asia. In V. Dale (ed), Effects of land use change on atmospheric $\mathrm{CO} 2$ concentrations: Southeast Asia as a case study, Springer Verlag, New York, Ch. 3, 1994.

Jenny, $\mathrm{H}$. The soil resource origin and behavior. Springer Verlag, New York, 1980.

Lugo, A.E. and S. Brown. Tropical forests as sinks of atmospheric carbon. Forest Ecology and Management 54: 239-255, 1992.

Lugo, A.E., M.J. Sanchez, and S. Brown. Land use and organic carbon content of some subtropical soils. Plant and Soil 96: 185-196, 1986.

Nelson, R., R. Swift, and W. Krabill. Using airborne lasers to estimate forest canopy and stand characteristics. Journal of Forestry 86: 31-38, 1988.

Olson, J.S., J.A. Watts, and L.J. Allison. Carbon in live vegetation of major world ecosystems, DOE/NBB-0037, National Technical Information Service, Springfield, VA, 1983.

Parton, W.J., D.S. Schimel, C.V.Cole, and D.S. Ojima. Analysis of factors controlling soil organic matter in Great Plains grasslands. Soil Science Society of America Journal 51: 11731179, 1987.

Post, W.M., W.R. Emanuel, P.J. Zinke, and A.G. Stangenberger. Soil carbon pools and world life zones. Nature 298: 156-159, 1982.

Prentice, I.C., W. Cramer, S.P. Harrison, R. Leemans, R.A. Monserud, and A. M. Solomon. A global biome model based on plant physiology and dominance, soil properties, and climate. Journal of Biogeography 19: 117-134, 1992.

Richards, J.F. and E.P. Flint. A century of land use change in South and Southeast Asia. In V. Dale (ed), Effects of land use change on atmospheric $\mathrm{CO} 2$ concentrations: Southeast Asia as a case study, Springer Verlag, New York, Ch. 2, 1994.

Risser, P.G. and L.R. Iverson. Geographic information systems and natural resource issues at the state level. In D.B. Botkin, M.E. Casswell, J.E. Estes, and A.A. Orio (eds.), Our role in changing the global environment: what can we do about large scale environmental issues? Academic Press, New York, pp. 231-239, 1988.

Sanchez, P.A. Properties and management of soils in the topics. John Wiley and Sons, New York, 1976.

Skole, D. and C. Tucker. Tropical deforestation and habitat fragmentation in the Amazon: satellite data from 1978 to 1988. Science 260: 1095-1910.

Tosi, J. and R.F. Voertman. Some environmental factors in the economic development of the tropics. Economic Geography 40: 189-205, 1964.

Weck, J. An improved CVP-index for the delimination of the potential productivity zones of forest lands of India. Indian Forester 96: 565-572, 1970.

Whitmore, T.C. Tropical rain forests of the Far East, 2nd Edition. Clarendon Press, Oxford, 1984.

Whittaker, R.H. and G.E. Likens. Carbon in the biota. In G.M. Woodwell and E.V. Pecan (eds.), Carbon and the biosphere, CONF-720510, National Technical Information Service, Springfield, VA, pp. 281-302, 1973.

Zinke, P.J., A.G. Stangenberger, W.M. Post, W.R. Emanuel, and J.S. Olson. Worldwide organic soil carbon and nitrogen data. ORNL/TM-8857, Oak Ridge National Laboratory, Environmental Sciences Division, Oak Ridge, TN, 141, 1984. 
MLE $=0$ 